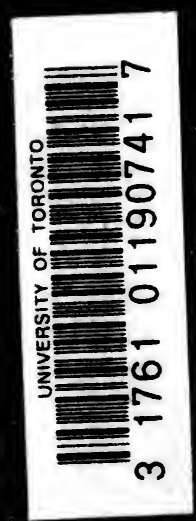


r 


COLUMBIA UNIVERSITY STUDIES IN ENGLISH AND COMPARATIVE LITERATURE

\section{DICKENS, READE, AND COLLINS SENSATION NOVELISTS}




\section{COLUMBIA UNIVERSITY PRESS}

SALES AGENTS

NEW YORK

LEMCKE \& BUECHNER

30-32 East 27th Street

LONDON

HUMPHREY MILFORD

Amen Corner, E.C.

SHANGHAI

EDWARD EVANS \& SONS, LTD.

30 North Szechoen Road 


\title{
DICKENS, READE, AND COLLINS
}

\section{SENSATION NOVELISTS}

\author{
A STUDY IN THE CONDITIONS AND \\ THEORIES OF NOVEL WRITINC, \\ IN VICTORIAN ENGLAND
}

\author{
BY \\ WALTER C. ${ }^{\circ}$ PHILLIPS
}

Submitted in Partial Fulfilment of the Requirements for the Degree of Doctor of Philosophy, in the Faculty of Philosophy, Columbia University

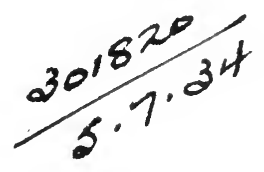

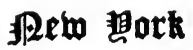 \\ COLUMBIA UNIVERSITY PRESS
}

1919 


\section{Copyright, 1919 \\ By Columbia University Press}

Printed from type, May, 1919

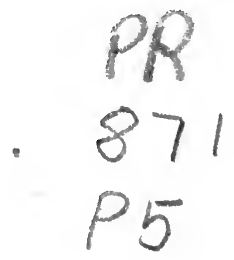

THE PLIMPTON PRESS $\cdot$ NORWOOD $\cdot$ MAss $\cdot \boldsymbol{U} \cdot \mathbf{s} \cdot \mathbf{A}$ 
TO THOSE

WHO MADE THIS STUDY POSSIBLE 



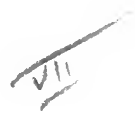

\section{PREFACE}

Dickens once condemned a doctrinaire preface by his friend Collins on the principle that a book of all things ought to stand by itself. Such admirable sense, it seems, ought to be heeded generally, especially by those who from time to time with great labor perpetrate books about better books. But the temerity apparent in writing about Dickens at all nowadays will probably seem equal to a preface in the true Victorian manner. If such an attempt is not to need apology, it certainly requires definition.

Hitherto the study of Victorian letters has been confined almost entirely to biography and esthetics. Yet as a matter of common knowledge that which distinguishes Victorian from other times, and chiefly explains the problems in its esthetics, is the social and intellectual change which made the many arbiters of taste. It is common knowledge that this revolution made novel and periodical the favorite literary forms. But the specific ways in which it affected the writer of fiction - the opportunities and ideals it encouraged, the changes it wrought in narrative form, the interaction of periodical and novel upon each other - have never been stated connectedly. The object of this study is an outline statement of these new forces as they affected Dickens and his followers. It aims primarily to present the problems and opportunities of fiction-writing as the Victorians saw them sixty years ago. The book purports to be nothing more than a beginning upon a broad subject. To blaze a trail through the wilderness of trade conditions from 1800 to 1850 is difficult, for in the present state of vii 
bibliography the results depend somewhat upon diligence, more upon chance. Moreover, the narrative is incomplete without reference to the French, who had earlier experimented in low prices and periodical publications. Twentyfive years hence, when this chaotic period is better known, the generalizations in this study will have been reinforced and elaborated, I hope, not changed. Likewise, leaving aside natural inclination of the Dickensians to the theatrical, the tradition of diabolism in English prose romance does not entirely account for their sensationalism. There are obscure, intangible influences from the French here also. These are by no means exhausted by Reade's known appropriation of French narrative. After Scott, say in Ainsworth, English prose romance was experimenting; and how much or in what manner Dickens's followers later were affected by Victor Hugo and Eugène Sue there is little means of saying.

At the end of the task it is pleasant to acknowledge kindnesses encountered in its course. I owe thanks to the staff at the Columbia University Library and to that of the John Hay Library in Providence for pains in making available obscure novels and obscurer magazines, especially to Mr. T. P. Ayer, while he was reference librarian at Brown, and later to Miss E. R. Blanchard, his successor. Mr. Crawford of The Toronto Globe enabled me to obtain some controversial papers of Reade which have not been reprinted. Dr. Robert S. Forsythe of Adelbert College kindly called my attention to some obscure but significant facts which I had missed. Some years ago a preceptor of my undergraduate study, Professor G. W. Benedict of Brown, stimulated my interest in Reade, and to him I am indebted for various useful hints during the writing. Professor G. P. Krapp of Columbia also aided in the formation of several chapters. My chief debt is to Professor A. H. Thorndike, whose interest in the study and whose helpfulness have been invaluable. For judicious 
help in the difficult places, which have been numerous, for unfailing counsel and pains in the formation of the manuscript, I have reason to thank him generously. The nature of such debt students of English at Columbia can best appreciate.

Providence, May, 1918

W. C. P. 


\section{CONTENTS}

CHAPTER

PAGE

I. Preliminary: The Sensational in Modern English

Prose Fiction........................... 1

1. The Appeal to Fear in the Modern English Novel.. 1

2. Victorian Sensation Novels................. 14

II. The Background of Sensationalism .............. 37

Foreword $\ldots \ldots \ldots \ldots \ldots \ldots \ldots \ldots \ldots \ldots, \quad 37$

3. The Rise of Cheap Books.................. 38

4. The Novelist as Wage Earner................ 57

5. Miscellany and Serial Fiction................ 68

6. Novelist and Public........................ 91

Summary $\ldots \ldots \ldots \ldots \ldots \ldots \ldots \ldots \ldots \ldots \ldots, 106$

III. The School of Dickens.................... 109

7. The Literary Fraternalism of Dickens, Reade, and Collins................................. 109

8. Their Creed of Fiction.................. 124

IV. The Native Tradition of Terrorism in the English

Nover.................................. 152

Foreword $\ldots \ldots \ldots \ldots \ldots \ldots \ldots \ldots \ldots \ldots \ldots, 152$

9. I. The First Phase of the Byronic Hero........ 155

II. The Byronic Hero discredited in "Newgate Novels" ........................... 164

10. The Common Characteristics of the Dickensians as

Sensationalists ...................... 181

11. Reade's Reduction of Sensation Principles to Absurdity 201

Summary.............................. 218

BibLIOGRAPHY $\ldots \ldots \ldots \ldots \ldots \ldots \ldots \ldots \ldots \ldots, 223$ 


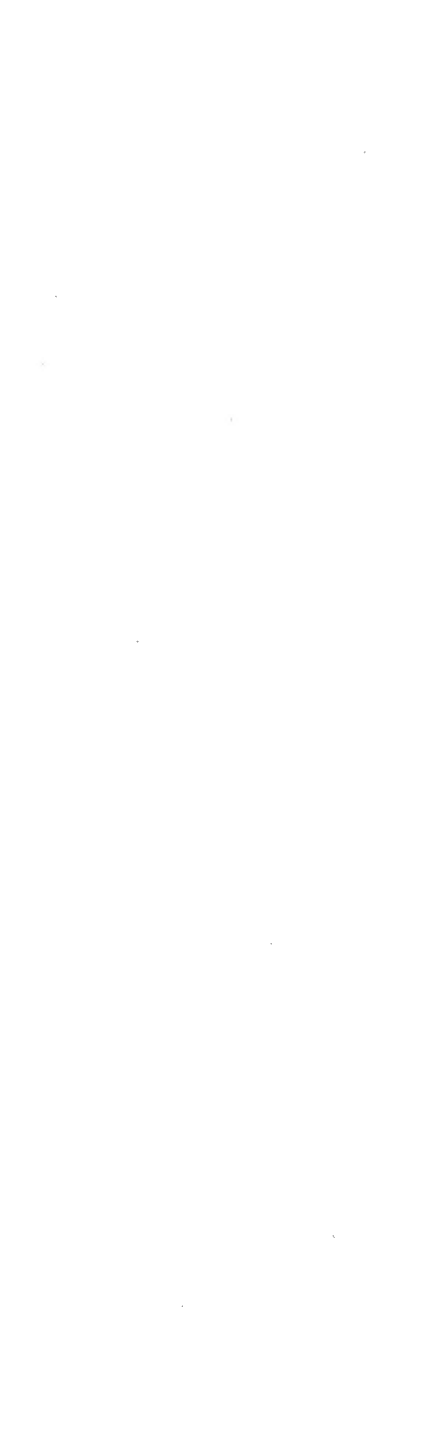

(

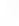




\title{
DICKENS, READE, AND COLLINS
}

\section{SENSATION NOVELISTS}

\author{
CHAPTER I \\ THE SENSATIONAL ELEMENT IN MODERN \\ ENGLISH FICTION
}

1. The Appeal to Fear in Modern English Prose Fiction

IN $A$ Winter Courtship Sarah Orne Jewett relates the manner in which Jefferson Briley, an aged New England mail-driver, was taken on the road, despite his formidable pistol, by a widow as sere and yellow as himself. Eighteen years of his seven-mile route daily except Sundays, behind a mare who was not young when she and her master undertook the task together, has driven Jefferson to revolt from a prosy lot. On this chilly winter morning, as he drives along with Widow Tobin for a passenger, he regales her with narratives about the desperadoes of the West. His fancy lingers fondly on the exhilarating dangers to the driver as the coach swings crazily above yawning cañons and down mountainous declivities. To the best of descriptive powers, based obviously upon no small acquaintance with the Jesse James style of frontier romance, he pictures the robbing of the express car by masked bandits, and speculates naively on the manner of men these terrible fellows are in their less picturesque hours. That, Jefferson 
remarks very disingenuously, is the life he would see in his declining years. "Men folks be brave by nature," sighs the widow, though she knows better, and draws poor tame old Jefferson into her net. Jefferson's wild visions end in a meek surrender a second time to the marital yoke; but his literary leanings are typical of the modern reader. Nowadays, when everybody reads, and there is something for everybody to read, popular literature of necessity is fragmentary, sentimental, and sensational. The millions, like Jefferson Briley, look to it to provide the variety and the adventurous experience which life itself does not bring. When the business of existence is prone to arrange itself into so many hours daily of shop, counter, or desk, popular fiction, whether in form of drama, novel, or moving-picture film, must meet a perennial demand for violent emotional thrills. Whatever sources of appeal may come or go, there is one which from the very structure of modern democratic society seldom bids for applause unheeded - that is, the appeal to fear.

In English fiction this appeal has been notably significant since Walpole's Castle of Otranto. From the preface to the second edition of that novel we learn that the story represented a conscious and deliberate revolt from "a strict adherence to common life" because such adherence had dammed up the resources of fancy. The appeal to fear has been especially insistent in our fiction for slightly less than a century - it may be said to have found more cogent and more popular expression in Dickens than it enjoyed before, partly because Dickens himself was a democrat in a sense that none of his great English contemporary rivals were, and partly because his beginning as a man of letters was coincident with the most notable extension of the reading public and of reading since the Renaissance. In its origin, then, a literary reaction from the canons of the age of prose 
and reason, the appeal to fear, primarily through this extraordinary enlargement of the circle of readers, becomes a stock appeal of modern popular novels.

The magnitude of this extension of the public can best be suggested by figures. At the end of Chapter 26, volume 8 , of his Popular History of England, Charles Knight quotes an estimate by Burke that in the final decade of the eighteenth century habitual readers in England numbered from 80,000 to $90,000 .^{1}$ In 1832 , five years before the appearance of Pickwick in shilling numbers, The Penny Magazine, published by the Society for the Diffusion of Useful Knowledge, attained a circulation of 200,000; and was estimated by its historian, Charles Knight, to have had a million readers. In 1838 The Posthumous Papers of the Pickwick $C l u b$, as contrasted with The Penny Magazine, a private venture in entertaining literature, were selling to the extent of about 40,000 copies of the monthly issues. Slightly later, when Dickens embarked upon periodical literature independently, in 'Master Humphrey's Clock, the public, believing that the title promised a new novel, bought 70,000 copies of the first issue. Twenty years later yet, The Cornhill, a shilling magazine edited by Thackeray, disposed of about 110,000 numbers of its first issue, and then settled back to a permanent subscription list of from 80,000 to 90,000 ; or, roughly, a subscriber for every reader that had existed sixty or seventy years earlier. The full significance of the sales of Thackeray's magazine does not appear unless we recall that another very popular and able shilling miscellany, Macmillan's Magazine, with Professor Masson as editor, began at almost the same time, with almost equal success.

1 Professor W. P. Trent, an acknowledged authoiity on minutiae of eighteenth-century bibliography, is of the opirion that the number is too small. Knight quotes the same figures in Passages of a Working Life, vol. 2, ch. 9, p. 184. 
How many fold the million readers of the Reform year had increased in these flourishing days of cheap periodicals no one knows. Knight, the best authority, calls the figures from mid-century "unmanageable."

Beneath these scattered facts lies the essential explanation of the disproportionate esteem of fiction and periodicals of "the casual, the trivial, and the sensational" - that marked Victorian literature and that marks our own. A new public with new tastes effected the complete remaking of trade in printed matter and a new and unheard-of scale of remuneration for popular writers. In this readjustment no single figure was more influential than Dickens, both as a story-teller and as a purveyor of novel and cheap miscellany. More than his rivals he adapted his art and the means of disseminating it to the new possibilities that were opening before writers who could at once please and lead the new taste. 1837, the year when Pickwick began in shilling numbers, was a fortunate time. The more pretentious magazines like Blackwood's, Fraser's, and Colburn's New Monthly were firmly established with middle-class readers; the reduction of the paper tax, which made possible cheaper and more popular periodicals, like Bentley's Miscellany and those which Dickens later owned and edited, had just been made. Weekly critical journals like The Literary Gazette (1817), The Athenaeum, and The Spectator (both begun in 1828), combining in a popular way the advantages of the elaborate articles in the quarterlies with those of the daily editorial, were already offering records of current politics, literature, and art. Yet the overwhelming popularity of the novel was still delayed. The number of novels appearing between 1815 and 1850 was by no means disproportionate. According to Knight, ${ }^{1}$ during those years there had been published in England 10,300 volumes of divinity; 4900 of

1 Popular History of England, vol. VIII, note to ch. 26. 
history and geography; 3500 of fiction; 3400 of drama and poetry; 2500 of scientific works; and 2460 devoted to the arts. Still, if its production had not been excessive, there long had been a growing awareness among writers that the novel could be made to serve serious purposes for readers who were not cultivated. Godwin's preface to Caleb Wil- liams makes clear that the story intended dramatization of some ideas from Political Justice for those who never read philosophy. Bulwer in 1830 had begun the vogue of what Professor Cazamain calls le Roman social with Paul Clifford, an attack upon the penal code. Disraeli, finding his political program unpalatable to the public in pamphlet form, embodied it in his trilogy of purpose novels, Coningsby, Sybil, and Tancred. By the time of Oliver Twist it was well understood that the novel might readily be made to serve a cause or a personal ambition.

Yet a novelist beginning about 1840, though he set his course as skillfully as Dickens ultimately did in the channel of new opportunities, could not escape great indebtedness to the waning romance. Writing professedly with the new elements of the literary audience in mind, and adapting his fiction as well to new methods of publication, he was more indebted to that waning romance than criticism has generally indicated. The reasons for this oversight are obvious and critically correct. Dickens was not only the successor of Scott and Byron, but he was also the delineator of the byways and eccentric folk of mid-century London. And so great was his originality in this province of his art that it has tended to obscure the kind and quality of plot he employed. The customary dicta of critics who look back to Smollett and Ben Jonson for kindred methods and characters describe only one aspect of his fiction. As to the stories he told as such, criticism has varied little; in the novelist's own day, Bagehot, Lewes, and Ruskin recognized and 
deprecated the qualities that a new school has designated in the same terms - as melodramatic and sensational.

Historically, in so far as this sensational tendency belongs solely to literary history, and forms a narrative tradition, its course can be indicated in few words. From"the end of the eighteenth century, when makers of fiction followed the direction of Walpole's revolt, and adopted the appeal to fear as a primary motive, some of the best powers of invention for the next six or seven decades were devoted chiefly to the elaboration of a terrible protagonist, half human, half demoniac. The terror that he inspired was the direct measure of his success. As in all revolt the first manifestations were most violent, and its results are least credible as reflections of conceivable human experience; the favorite figure of such romances was originally supernatural or else was brought into direct encounter with supernatural forces; then, like Lara and the early heroes of Bulwer-Lytton, a frankly human being of ambiguous moral nature, partly admirable, mostly vicious; and finally the stereotyped villain of melodramatic stage and shilling-shocker. In such a revolt the principles upon which it depends originally have only the most general definition; they rest upon the conviction that existing ideals are despicable and intolerable. To trace the influence of this revolt is to indicate the development of the sensational, melodramatic element in modern English prose fiction to its culmination in the novels of Dickens and his chief satellites; for they inherited the results of this experimentation, and formulated it in accordance with the life and taste of their own day.

There is, then, no want of continuity between the romance that Walpole and the Terrorists wrote at the end of the eighteenth century, and that which Dickens and his followers wrote in the middle of the nineteenth. Its pathway lies through the domain of Byron and of Scott, and its goal is 
melodrama which approaches the stage variety. Scott, a keen student of prose romance, saw the direction of the method for which Mrs. Radcliffe won respect. Toward the end of his memoir of that lady, he remarked: "The species of romance which Mrs. Radcliffe introduced bears nearly the same relation to the novel that the modern anomaly entitled a 'melo-drama' does to the proper drama. It does not appeal to the judgment by a deep delineation of human feeling, or stir the passions by scenes of deep pathos, or awaken the fancy by tracing out with spirit and vivacity the lighter traces of life and manners, or excite mirth by strong representations of the ludicrous or humorous. In other words it attains its interest neither by the path of comedy nor of tragedy; and yet it has a deep, decided, and powerful effect, gained by means independent of both - by an appeal, in one word, to fear, whether excited by natural dangers or by the suggestions of superstition. The force, therefore, of the production lies in the delineation of external incident, while the characters of the agents ... are entirely subordinate to the scenes in which they are placed.... The persons introduced - and here also the correspondence holds betwixt the melo-drama and the romantic novel - bear the features, not of individuals, but of the class to which they belong." Now when the force of the production depends upon external incident, there is a new emphasis upon arti- : ficial plot. Moreover, when the novelist works with the Faust motive and with personages half human, half demoniac, ! like Maturin's Melmoth, solutions of the plot such as those in The Monk, where Satan comes in person to claim the false priest Ambrosio, or in Melmoth, where the protagonist disappears in thin air over the Irish Sea, are inevitable and appropriate. The conditions of the story are unintelligible, humanly speaking, and so is the conclusion. When the 1 crime is the sale of a soul, the hangman is impotent. But * 
when supernatural themes are discredited, as they were by the twenties, the narrator was unwilling to forego the advantages he had derived from superstition and theology. If the fiend could no longer carry off Ambrosio in 1840, the novelist could invoke opportune shipwreck or bolt of lightning to achieve the same result.

The contribution of Byron and of Scott to the sensational tradition consists essentially in rationalizing and rendering more credible the characteristically supernatural melodrama of the Terrorists. From it Byron borrowed the ruffianly hero whom he celebrated under half a dozen names. The villain of The Castle of Udolpho, elaborated into Schedoni, the false monk in The Italian, becomes the hero of The Giaour and Lara. Mrs. Radcliffe had progressively diminished suggestions of the supernatural through her novels, so that Schedoni, when Byron appropriated him, was almost "entirely divested of it. Byron made his melodrama frankly mundane, and successfully substituted a more or less genuine oriental atmosphere for haunted Gothic castle, monastery, and other machinery of crude terror. In neither Byron nor Scott does the melodrama exist for its own sake. In Lara and the companion pieces it provides an appropriate narrative framework for exploitation of Byron's "satanic" ego. Yet if it is, strictly speaking, subordinate in Byron's design, its value, from the conception of the character the stories illustrate, is directly dependent upon its luridity and violence. The more terrific the incidents of the intrigue, the greater the likelihood of vividly impressing the ruffianly hero. Immediately, indeed, Byron's influence upon fiction was not less than Scott's; in the tradition with which this study is concerned it was indubitably far stronger. Its narrative methods and values, which more than others determined the character of Victorian "sensation fiction," are detailed in a later chapter. 
Scott, it has appeared, was a keen analyst of Terrorism. Being no less a shrewd judge of what the readers of his novels wanted, he perceived much in Gothicism that was highly useful, and sought material analogous to that of the Terrorists for similar effects. He was constantly dressing up his historical dramas with the kind of melodramatic incident that delighted Dickens and Reade. Working mainly in the dramatic stories of history, Scott freely employed the romancer's license in favor of sensationalism. He carried on the popular taste for terror in a series of studies based upon Scotch superstition. In Guy Mannering, the prophecy and curse of Meg Merrilies, the ruin where she protects Harry Bertram from the smugglers and gypsies while Hatteraick's mate is dying, the Kaim of Derncleugh, the only place where Meg's spirit can free itself from the flesh, and the strange fulfillment of Mannering's horoscope for young Ellangowan are peculiarly Gothic effects. Guy Mannering indeed might be styled a Gothic novel as written by a man of sense. But Scott knew that popular superstition as a source of sensational appeal was becoming stale and unprofitable. He records his dubiety about later experiments in the preface to The Monastery, dated November, 1830. Here, he says, "From the discredit attached to the vulgar and more common modes in which Scotch superstition displays itself, the Author was induced to have recourse to the beautiful, though almost forgotten, theory of astral spirits"; but the result, The White Lady of Avenel, was, he realizes, a failure. "Either the Author executed his purpose badly, or the public did not approve of it." Scott thought both explanations true. He admits that The Monastery is a badly constructed story. For the rest, he very significantly remarks: "Machinery remained - the introduction of the supernatural and marvelous, the resort of distressed authors since the days of Horace, but whose privileges as a sanctuary have been disputed in the present age and well-nigh exploded." 
As has been intimated, Scott's chief contribution to sensational narrative as it persisted into Victorian times lies elsewhere. He had no scruples about altering specific historical fact if he could thereby achieve a narrative effect. He extends the life of the villainous De la Marck in Quentin Durward four years beyond the time history assigns in order to kill him off dramatically. In Kenilworth, he bases the account of the Countess Amy's death upon a chronicle quite at variance with the findings of the court which tried Leicester. Furthermore, he grafted episodes originally unconnected with his story upon it for sensational effect. There is a striking example in Old Mortality in young Morton's escape from the fanatical Cameronians. After the Covenanters were routed at Bothwell Bridge, Morton accidentally asked shelter in a house where ten of the fanatics had taken refuge. The young man had already roused their hatred by refusal to assent to their extreme measures; and now that Providence had given him into their hands, the Cameronians felt that the best service they could do their cause in the day of defeat was to rid it of a lukewarm adherent. As it is Sunday evening, however, they resolve not to carry out the butchery until after midnight, though their zeal brooks the delay very ill. The most militant of the captors is already hastening the hands of the timepiece toward twelve, when Cuddie Headrigg breaks in, accompanied by a band of Claverhouse's redcoats. This deferring the execution until the close of the Sabbath was appropriated, according to Scott's note, from the contemporary experience of a Scotch exciseman with the smugglers.

Scott, then, as he affects sensational methods of narrative, though not immediately more potent than Byron, was, like him, a rationalizing force. Byron discarded supernaturalism in favor of sentimental villainy in an oriental setting; Scott experimented with substitutes for supernaturalism, 
and ultimately left models shorn alike of diabolism and of sentimental villainy. It is this use of the romancer's license with reservation that constitutes Scott's great contribution to the method of narrative we are considering. Before broken health brought the Waverley series to a close, he had indicated in Kenilworth, Old Mortality, Quentin Durward, Redgauntlet a self-respecting road for the appeal to fear. Still, no more than in Byron was melodrama the end and aim of the narrative; with Scott it is the spice intended to give additional zest to the historical dramas in which he generally works. Both romancers perceived its great utility - both employed and developed it; neither gave it code or formulas.

When Scott died the old set of romantic motives in fiction were fast breaking down. Simultaneously with the disintegration came the rise of the great uncultivated audience. The resultant uncertainty and ambiguity of purpose in Ainsworth and Bulwer will later be noted as of importance in the development of the sensational method. Dickens, the plot-maker, as opposed to Dickens the delineator of human oddities, brought down to date the essential appeal of The Romance of the Forest, and adapted it to the prejudices, credulity, and taste of the audience for which he wrote. In the work of his 'prentice hand, notably in Oliver Twist and in Barnaby Rudge, this kinship with older patterns of romance lies at the surface. But the charnel-house horrors of Oliver are by no means exceptional in his narrative. From the scene in which Sikes brutally murders his mistress through the opium-tainted atmosphere of Edwin Drood,there is no full-length story of his without its generous reliance upon the most brutal stimulants to fear.

Indeed, reliance upon such material was a canon of art for Dickens and those who followed most ably and most closely in his steps. Together with Wilkie Collins and Charles Reade, who by the early fifties had reinforced him 
by adoption of his narrative preferences and practices, he gave the sensational tendency in our fiction a creed and definite methods. This creed, however, has no single prolegomena. Still, few or no long inferencés are necessary to ascertain their theories of their art, for they left in various incidental pieces, such as letters, controversial pieces, and criticisms of contemporaries or of each other, intelligible enough record. All this incidental criticism is defined by their consistent and unequivocal practice.

Examination of these documents gives a new definiteness to the term The School of Dickens. For such entertainment as they provided they had tolerably definite formulas. These formulas disclose not only an essential unity of ideas among our triumvirate, but also afford a key to much in craftsmanship that seems grotesque, violent, and theatrical, as well as to much that seems strangely vivid and masterly in adroitness of narrative manipulation. They write, as they tell us, the romance of the here and now, not for the cultivated or the sophisticated, but for the public - the whole public. No single utterance of theirs is perhaps more significant of their joint aims and preferences than that which Collins prefixed to Basil, his second novel. "Believing that the novel and the play are twin-sisters in the family of fiction; and that one is drama narrated as the other is drama acted; and that all the deep ... strong emotions that the play-writer is privileged to excite, the novel writer is privileged to excite also, I have not thought it necessary . . . to adhere to everyday realities only." Strong emotions, unusual incident, dramatic method - such preferences recall perhaps the storm in Copperfield, the execution of Carton, the homecoming of Gerard the monk, and many more, not a few of which ill accord with the standards of present-day taste. Collins's parallel of the theater, in fact, points to the narrative method which they persistently championed. At 
bottom their method aimed, by means of adapting to the novel some of the advantages and necessary restraint of play-writing, to impart a vivacity and verisimilitude hitherto insufficiently developed in English prose fiction. Specifically the characters must express themselves by words and act more than had been the custom; they must be expressed by the writer's comments less. Again, the full emotional value of the material was to be stressed as the theater stresses it. Hence climaxes arranged on the stage plan. Whether or not these arose necessarily from the characters in the narrative is secondary with the-Dickens group. They and their audience, one suspects, often found the fortuitous more appalling than the logical. If then for Collins's word drama we read melodrama, we have roughly what our trio meant by the parallel, and can understand why they were fond of describing their own novels as dramatic.

Sensationalism, or the sensation novel, as Victorian reviewers dubbed it, had, then, a fairly definite meaning and a long literary tradition. It was romance of the present consciously adapted to new conditions and to new public; and found, like its prototype, material in records of crime and'villainy. These in some measure for their own sake it consciously stresses in the adventures of a Lara, Redgauntlet, Fagin, Riderhood, Count Fosco. Its great exponents in Victorian times were Dickens, Reade, and Collins, whose specialized narrative form effected its highest development. Their example found numerous imitators, most $t_{\alpha_{2}}$ of whom lacked their facility and power, some of whon were quite destitute of their sense of the responsibilities of the artist. In the hands of these, sensation writing became the reproach and abomination of Victorian popular literature. Critic and moralist alike descried in it the collapse of taste and truth in the novel, and pointed their finger at Dickens with the accusatory "Thou art the man." 
With this outline of the rise and nature of Victorian sensational narrative in mind, we may proceed to a more extended account of the form it took two generations ago and of its heyday in the English novel.

\section{Victorian Sensation Novels}

Consideration of the sensational trend in Dickens's work necessarily restricts to that which is least admirable in his art. The best recent criticism, such as Gissing's, Chesterton's, and Professor Hugh Walker's, has especially insisted on an idea which Bagehot expressed in 1858. It has become a truism that when Dickens is chiefly concerned with plot, his favorite description of himself as "the inimitable" is highly ambiguous. Here it is precisely with the narrative art that we have to do - with plot, the handling of incident, and the narrative rhetoric. Not Pickwick, the inexhaustible humor, or the vivid knowledge of London; but the death of Little Nell, the finding of Steerforth's body, the spontaneous combustion of Krook, the murder of Nance, the execution of Carton, are the material - this is the sensation stuff that could be and was widely imitated by lesser men.

For general illustration of the Dickensian sensationalism, that preface by Collins previously referred to, which insists upon the parallelism of novel and play, the portrayal of strong emotions, and selection of incident not bounded by everyday probabilities, furnishes a helpful guide. This quality, as has been intimated, especially dominates early novels like Oliver Twist; the hue which the common creed of the Dickens school imparted to their fiction is nowhere more clearly marked. Oliver, the parish boy, is really the illegitimate son of a gentleman of some wealth by a woman whose disgrace drove her to the almshouse where the lad was born. There he spends some childhood years, the 
wretchedness of his life aggravated by the parsimony and brutality of the management. Apprenticed to the undertaker, Oliver finds his lot unimproved, and decides that any change must be for the better. He sets off for London. On the road he falls in with The Artful Dodger, one of a band of London thieves, who befriends him. Finding that Oliver has no destination in the city, the Dodger offers him a lodging with the gang whom Fagin directs. Owing to the precariousness of their trade, the thieves are always on the lookout for recruits; and a recruit, all unwittingly, Oliver becomes. As soon as he has been coached a little at pocket-picking, he is sent out upon the streets, where his inexpertness and ignorance cause him to be taken in his first offense. Rescued by Mr. Brownlow (who is really his grandfather), Oliver is shortly found by one of the band, and tricked into returning to Fagin. Next he is sent with Bill Sikes, the housebreaker, to crack a country crib, Oliver's part being to effect an entrance through a small window in order to admit his confederates. In the attempt Oliver is wounded by a gunshot. A second time the boy is rescued from the band. The first expedition in which he engaged resulted in his meeting his grandfather; the second brings him to an aunt. Meanwhile, however, Oliver's half-brother, who is withholding from him considerable property, discovers the lad's whereabouts, and contracts with Fagin to have him made into an unpardonable criminal. Once more the thieves kindap him. But one of them, Nancy, the mistress of Sikes, takes pity on him and communicates with Mr. Brownlow, whom she knows to be interested in the boy. But Nancy, having fallen under suspicion of the chief, is followed and her plan discovered. Fagin intrusts the vengeance of the band to Sikes, who swiftly and brutally kills the girl. Then retribution falls fast and heavily upon the gang. Sikes, in a last effort to escape, involuntarily 
hangs himself in an effort to descend from a roof; Fagin is apprehended and goes insane in prison.

This is fearful enough certainly, but conveys little notion of the particularity of horrors in the dramatic, sensational novel. Bill Sikes, for instance, is at considerable pains to make us aware what a terrible fellow he is. When Fagin is preparing him for the announcement of Nancy's perfidy, the master thief puts the case hypothetically, inquiring what Sikes would do if The Dodger had "split." "I'd grind his skull under the iron heel of my boot into as many grains as there are hairs upon his head," Bill retorts. "Suppose I did," Fagin inquires. "If I was tried with you," says the ever-ready housebreaker, "I'd fall upon you with them (the manacles) in the open court, and beat your brains out afore the people." Sikes having made clear that his vengeance would be without respect of persons, Fagin acquaints him with the culprit's name, brandishing the while one hand in the air and wiping the foam from his mouth with the other. "Hell's fire," roars Sikes, "let me go," and off he rushes to his wretched mistress, whose face he pounds to a jelly with the butt of a revolver. This being insufficient, he finishes off the job by a blow with "a heavy club."

A chapter or two further on we have the murderer at bay. Unable to keep out of London, he is betrayed in his usual haunts by the presence of his dog. The mob closes about the house where he hoped for concealment; Sikes, knowing the place to be well locked, throws up the window and dramatically defies his pursuers thus - "Do your worst! I'll cheat you yet." Whereupon "of all the terrific yells that ever fell on mortal ears, none could exceed the cry of the infuriated throng." Sikes had planned to escape by letting himself down from the roof into a ditch which ran behind the house; but when he succeeds in getting upon the housetop he discovers that the tide has ebbed, leaving 
the ditch a sea of mud. Perceiving the intention and the impossibility of its fulfillment, the crowd "raised a cry of triumphant execration to which all their previous shouting had been whispers." Still trusting to the chance of escaping by way of the ditch, Sikes fastens his rope to the chimney and intends to adjust the noose at the other end under his armpits. "At that very moment the murderer, looking behind him on the roof, threw his arms over his head and uttered a yell of terror.

"'The eyes again!' he cried in an unearthly screech. Staggering as if struck by lightning, he lost his balance and tumbled over the parapet. The noose was at his neck, it ran up with his weight, tight as a bow string, and swift as an arrow it spread. He fell for five and thirty feet. There was a sudden jerk, a terrific convulsion of the limbs, and there he hung with the open knife clenched in his stiffening hand. . . . A dog which had lain contented till now ran backwards and forwards on the parapet, with a dismal howl, and collecting himself for a spring, jumped for the dead man's shoulders. Missing his aim, he fell into the ditch, turning completely over as he went, and striking his head against a stone, dashed out his brains."

"This garishness is not the excrescence of immaturity, but a constant quality of Dickensian fiction. Quilp, in almost the next novel, would convince us that he too is a terrible fellow by eating eggs and shells together and by drinking boiling rum. Sikes's threat to beat out Fagin's brains with manacles Dickens makes good twice over in Great Expectations. Bleak House, which offhand perhaps does not recur to the memory as particularly sensational, illustrates nine varieties of grotesque and violent death. Among them are the spontaneous combustion of Mr. Krook, the self-poisoning of Lady Dedlock's former lover, insanity and malnutrition for one of the Chancery suitors, exposure and want for 
poor Jo, exposure and disgrace for Lady Dedlock, shooting for Mr. Tulkinghorn, and hanging presumably for the French maid who murdered him. Again, in Great Expectations, Dickens had a theme which was novel and sensational enough, one would think, without the elaboration of crude violence. The idea of a lad who befriends a convict, and who later is befriended in return by the convict's setting him up as a gentleman, certainly seems fertile and novel enough of itself. But Dickens was not of that opinion. He introduces a demented woman who had been deserted on her wedding day and had worn her bridal finery ever since. As a bit of gratuitous charnel-house horror the poor woman makes an end by burning to death in her faded wedding costume. Another character, Old Orlick, exists mainly to break a woman's skull with a chain, and narrowly to miss the opportunity of beating in Pip's with a hammer. But this is not all - the story of the first convict involves that of another whom the first has ample reason to hate. This hatred gives rise to more beating of heads with prisoner's manacles, and a final conflict which results for one rascal in drowning, for the other in fatal injuries. There are adventures of this precious pair which are kept largely in the background, such as the betrayal of a woman, child murder, and a death-grapple in which one woman strangles another. This constant emphasis from Oliver Twist to Edwin Drood upon the most brutal stimulants of fear suggests that to a considerable extent Dickens valued narrative material as it provided opportunities for such effects as those described. Indeed all these horrors are consonant with avowed narrative principles.

In addition to Dickens, the most distinguished adherents to these principles in Victorian times were Charles Reade and Wilkie Collins. Together they form a "school" of literature in a sense unusual among the English. Reade, 
the elder of these disciples, was an Oxford man, having taken his Bachelor's degree at Magdalen College, where he also won a fellowship in 1835 at the early age of 21 . The youngest of eleven children, Reade came of a substantial country family. His father was a squire of some property; his mother a remarkable woman from whom the novelist inherited, apparently, much of the eccentricity which marked his life. He had thought of medicine for a profession, but, finding a weak stomach quite unequal to the dissecting room, had turned to the law. Finally he had taken a law degree, though the stage commanded his enthusiasm. It is significant that Reade approached fiction through the drama. His aspiration to win renown as a playwright was so persistent that he caused the word "dramatist" to precede "novelist" upon his tombstone. Finally becoming acquainted with Tom Taylor, who through the fifties had an enviable reputation among theatrical folk, Reade collaborated with him in the successful comedy Masks and Faces, 1852. The plot of this play Reade utilized for his first novel Peg Woffington. Rather oddly Reade seems to have been unskillful and diffuse in stage construction, for he became master of one of the most direct and swift narrative styles in English prose fiction. At all events Taylor early suggested that his literary capabilities were better fitted for novel- than for play-writing. When this advice was repeated by the actress Laura Seymour, to whom Reade offered his play Christie Johnstone, he took it seriously; and in the fifties, already more than thirty-five years old, he began the series of novels by which he is chiefly remembered. Until her death in 1879 Mrs. Seymour remained his chief critic and adviser. His first stories, Peg Woffington and Christie Johnstone - though now, after The Cloister and the Hearth, probably the best known of his work - made no especial stir upon publication. It was not until 1856, with the appearance of $I t$ is 
Never too Late to Mend, a story dealing with the Australian gold fields and reform in the prison system, that Reade caught the public. From that time to his death in 1884 he was one of the most popular men of letters. After the death of Thackeray and of Dickens, he divided with George Eliot the reputation of being the greatest living novelist. After It is Never too Late to Mend came White Lies, 1857; Love me little, Love me long, 1859; The Cloister and the Hearth, 1861; Hard Cash, 1863; Griffith Gaunt, 1866; Foul Play, 1868; Put Yourself in his Place, 1870; A Terrible Temptation, 1871; The Wandering Heir, 1872; A Simpleton, 1872; A Woman Hater, 1877; A Perilous Secret, 1883.

William Wilkie Collins, who was named for two painters, - his father and Sir David Wilkie, - was ten years younger than Reade. While articled in the tea trade, the young man composed Antonina, a historical story, which so pleased his father that the elder Collins decided to put his son to the study of law. Wilkie's first published book was the biography of his father, who died in 1847 . He seems at this time to have been undecided whether painting or fiction was his vocation. Antonina, published in 1850 as an experiment, was tolerably well received. A year later he met Dickens, with whom he formed a life-long friendship. Dickens's favorable opinion of Basil in 1852 was probably a turning point in the younger man's life. Dickens, as the editor of a popular miscellany, found Collins clever and worth cultivating. Collins turned definitively to letters, and became an aide in Household Words, which afforded him his chief outlet until 1860. The Woman in While, brought out in All the Year Round, to which Household Words had given way in the year 'fifty-nine, won him a reputation as the foremost plot constructor of the time. Thereafter his reputation was not confined to England. His stories were regularly translated into other languages, and Collins himself 
sometimes felt that his foreign audience was more appreciative than the native. There is no doubt that he suffered more than Dickens and Reade from the reaction in favor of domestic stories. Always a serious, conscientious workman, he had no great knack of character drawing. At the same time his sensationalism at its best is not facile, like Reade's, nor sentimental like Dickens's; but massive and intellectual. After Basil in 1852 his main novels were Hide and Seek, 1854; The Dead Secret, 1857; The Woman in White, 1860; No Name, 1862; Armadale, 1866; The Moonstone, 1868; Man and Wife, 1870; Poor Miss Finch, 1872; The New Magdalen, 1873; The Law of the Lady, 1875; The Two Destinies, 1876; The Haunted Hotel, 1878; Jezebel's Daughter, 1880; The Black Robe, 1881; Heart and Science, 1883; I say No, 1884. Another story, Blind Love, which was running serially when Collins became fatally ill in 1889, was completed by Sir Walter Besant.

Hardly had Reade and Collins finally elected novelwriting as a profession, when a new variety of novel, with ideals sharply opposed to theirs, caught the fancy of the more serious part of the public. Down almost to mid-century romance had held popular preference in fiction. Just before 1850, however, there comes a sturdy revolt against this novel of horrors and violent death in favor of representations of life as it is. The quieter realistic story had not wanted the suffrage of critics from the time of Maria Edgeworth, nor, though it had been overshadowed by Scott and by Byron, had it wanted an audience. The critical bias in favor of realism appears in the contemporary reviews of Jane Austen and of Maturin. The Quarterly noticed Persuasion and Northanger Abbey, and Melmoth the Wanderer in the same number. Miss Austen's tales had justice, but poor Maturin was damned out of hand for attempting to palm off stale romantic excitements. He is accused of 
ignorance, rant, and blasphemy by The Quarterly. The Edinburgh, with that assumption of finality which characterized the early journalistic reviewers, announced that it was high time for criticism to step forward and abate this nuisance of diabolical fiction. So much for a book that had the admiration of Scott, Balzac, Baudelaire, and Rossetti. It may be said that the opposition taste and practice began to take precedence with Thackeray's Vanity Fair. Bulwer, always susceptible to changes in the market, and Lever, who began in Harry Lorrequer and Charles O'Malley as the Scott of the Napoleonic wars, soon followed. More substantial and partisan adherents than Bulwer and Lever took up the new cause in the persons of Anthony Trollope and George Eliot.

The opposition of these groups was sharp, sometimes even to the point of bitterness. Thackeray said of Dickens's work; "He knows that my books are a protest against his - that if one set are true, the other must be false." $\mathrm{He}$ complained in Catherine, of Oliver Twist, that Fagin's band are "a most agreeable set of rascals indeed, who have their virtues too, but not good company for any man. We had better pass them by in decent silence; for as no writer can or dare tell the whole truth about them, there is no need to give ex parte statement of their virtue." In Chapter 5 of Amos Barton, George Eliot foresees objections to her prosy clergyman - "a man whose virtues were not heroic, and who had no undetected crimes within his breast; who had not the slightest mystery hanging about him, but was palpably and unmistakably commonplace." Mrs. Farthingale, "to whom tragedy means ermine tippets, adultery, and murder," will not like him. That being the fact, says the .author, as conclusion of the whole matter, "you will easily find reading more to your taste, since I learn from the newspapers that many remarkable novels full of striking 
situations, thrilling incidents and eloquent writing, have appeared only within the last season." Trollope, writing of fellow workmen in Chapter 13 of his autobiography, expresses as his opinion of Dickens: "It has been the peculiarity and the marvel of this man's power that he invested his puppets with a charm that enabled him to dispense with human nature. There is a drollery about them, in my estimation, very much below the humour of Thackeray, but which has reached the intellect of all; while Thackeray's humour has escaped the intellect of many. Nor is the pathos of Dickens human. It is stagey and melodramatic. But it is so expressed that it touches every heart a little." A few pages later in the same chapter Trollope commends Wilkie Collins for excelling "all contemporaries in a certain most difficult branch of his art," construction; but adds, "such work," in which he is always conscious of the artifice, "gives me no pleasure." It is clear, then, that the realism which became ascendant with Vanity Fair was in a sense "high-brow" fiction. Having therefore the suffrage of the best reviews and of solid, conservative folk, it appears in contemporary records to be more popular than it really was. For example, Thackeray to a certain class seemed to beat Dickens "out of the world." Another representative lady, Charles Reade's mother, thought Dickens vulgar, though she was very fond of the heroines of G. P. R. James. Yet Thackeray himself supposed Dickens's instalment pamphlets of novels to have about four or five times as great a sale as his own.

Clearly the millions read Great Expectations, The Woman in White, Lady Audley's Secret, and Foul Play. The sensational, melodramatic story from the very condition of the public represented necessarily the popular tendency during the third quarter of the century; and one has only casually to turn the pages of The Athenaeum during the sixties to 
learn that its vogue was tremendous and, to the critics, disquieting. So general had such stories become that the reviewers invented a new name for them - sensation novels. This term was felt almost as a compound. Not the least disturbing characteristic about them, according to contemporary opinion, was that many were perpetrated by women. M. E. Braddon, Mrs. Wood, Ouida, Mrs. Norton, and others now almost entirely forgotten made themselves only less obnoxious than Wilkie Collins. A few titles culled almost at random from the book reviews of The Athenaeum will suggest something as to the turn that popular novels had taken. Here we find notices of Forbidden Fruit, The Trail of the Serpent, Nobly False, Lady Audley's Secret (also the secret of Margaret, Flavia, and others), The Last Days of. a Bachelor, The Law of Divorce, No Name, Such Things are, Held in Bondage, Clinton Maynard, A Tale of the World, The Flesh, and the Devil, Honor and Dishonor, The Interrupted Marriage, A Page from the Peerage, The Heiress and Her Lovers, Skating on Thin Ice. Punch, in May, 1862, published announcement of a Sensation Times, which was to devote itself "to Harrowing the Mind, making the Flesh Creep, causing the Hair to stand on End, giving Shocks to the Nervous System, destroying the Conventional Moralities, and generally unfitting the Public for the Prosaic Avocations of Life." "A novelist confined at Botany Bay, who expects shortly to obtain a ticket of leave, is to be editor." Reade and Boucicault's Foul Play, 1868, evoked a burlesque in Punch by Burnand entitled Chikken Hazard. The parody was prefaced by notice of engagement of a new novel company - "The Sensational Novel Company" (Limited) for Punch, the chief writers of which are the authors of - 
(A) 1. Never too Late for the Colleen Pogue (Reade and Dion Boucicault).

2. Dora's Vampire (allusion to Reade's play on Tennyson's poem).

3. Who's Griffith's (Gaunt)? (Reade's novel).

4. Hard Streets of London Assurance (Reade's Hard Cash and Boucicault's play London Assurance).

5. Peg Woffington's Long Strike (Reade's novel Peg Woffington).

6. The Double Carriage (Reade's play and novel, The Double Marriage, taken from the French).

7. Hunted Up (Dickens's Hunted Down).

(B) 1. The Woman with No Name (Collins's No Name and The Woman in White).

2. The Thoroughfare without a Heart (Dickens's and Collins's No Thoroughfare).

3. The 'idden 'and (Wilkie Collins's story, The Hidden Hand).

(C) 1. Lady Disorderly's Secret (Mrs. Maxwell's Lady Audley's Secret).

Punch further explains that "The editor's object has been to obtain the most startling, most thrilling, most exciting plot constructed by the most original romancers - whether from their own or foreign brains matters not - now in the country. The readers' time will not be wasted on pages of analysis of character, descriptive touches about sunsets, sunrises, trees, and the appearance of nature, which only impede the clear course of the story and tire the patience of the purchaser." Sensation writing drew attention from higher dignitaries than Mr. Punch, however; upon it the great reviews, like The Quarterly and The Contemporary, trained their heavy artillery. The Quarterly traced it to cheap magazines, railway bookstalls, and circulating 
libraries; The Contemporary, to a widespread corruption in society.

The sensation novel had no accepted definition or model. Nevertheless, some current attempts at explanation will facilitate a better understanding of the phenomenon. A writer in The Christian Remembrancer declares that "The one indispensable point in a sensational novel is that it should contain something abnormal and unnatural; something that induces in the simple idea a sort of thrill." Proceeding, then, to the heroines of Mrs. Maxwell and Mrs. Wood, he finds the objection to their stories in "the utter unrestraint" in which these women are permitted "to expatiate and develop their stormy, impulsive, passionate characters." "The heroines are charming because they are undisciplined." "This drop from the empire of reason" means "a consistent appeal to the animal part of our nature, and avows a preference for its manifestations, as though power and intensity came through it." The Quarterly in 1863 printed a review of twenty-four sensation novels, including among others of less note Lady Audley's Secret, Wilkie Collins's No Name, and Mrs. Wood's Danebury House. Asensation novel, as The Quarterly reviewer understands it, "as a matter of course abounds in incident. Indeed as a general rule it consists of nothing else - action! action! action! is the flrst thing needed, the second and the third. The human actors of the piece are, for the most part, but so many lay figures on which to exhibit a drapery of incident. Allowing for the necessary division of all characters of a tale into male and female, old and young, virtuous and vicious, there is hardly anything said or done by any one specimen of a class which might not with equal fitness be said or done by any other specimen of the same class. Every game is played with the same pieces, differing only in the moves." The critic distinguishes three charac- 
teristics in his specimens - proximity, personality, predilection to stories of crime. They are invariably stories of the day, he observes, because proximity makes the sensation more intense. "It is necessary to be near a mine in order to be blown up by the explosion." Moreover, "if a scandal of more than usual piquancy occurs in high life, or a crime of extraordinary horror figures among our causes célèbres, the sensationalist is immediately at hand to weave the incident into a thrilling tale with names and circumstances slightly disguised, so as at once to exercise the ingenuity of the reader in guessing the riddle." Finally, bigamy, which is a motive in eight of the twenty-four stories under consideration, adultery, and murder are favorite themes.

The causes for this epidemic as seen by contemporaries were many. In The Quarterly article just cited the periodicals, circulating libraries, and railway bookstalls are held chiefly accountable. Sensation fiction is a commercial product fitted to a commercial demand; it supplies the demand by appealing to the nerves instead of the imagination. But such explanation does not enable us to get on. Why did circulating libraries and bookstalls flourish? In the November Contemporary for 1873, Vincent Murray concluded a notice of Ouida's Held in Bondage, Tricotrin, Strathmore, and Chandos in much more lugubrious vein. "Precisely as certain diseased conditions of the body give rise to a craving for unnatural food, so do certain morbid conditions of mind produce an appetite for literary food which a sound mental organization would reject. Individual instances of such morbid affections are fit subjects of study for the physician only, and the fact that a silly and ignorant woman should write novels which are at once vulgar, nasty, and immoral in tendency could not in itself be a matter of interest to readers of The Contemporary Review. But that such books have a very large and increasing circulation should be a matter 
of painful interest to every decent man and woman in England. These books are issued by one of the first houses in the trade; they are written for and read by society." All of which high seriousness seems curiously misinformed.

We may come nearer a satisfactory understanding of sensationalism by other means. It was generally understood that Wilkie Collins's Woman in White, which ran through seven editions in six months, gave a new impetus to tales of mystery. By acute critics Collins was understood to be the counterpart of Mrs. Radcliffe brought down to date. By virtue of his intellectual power, however, Collins was conceded to be something more than a mere sensationalist; as The Nation said, he required the same sort of effort that Froude or Motley demands. The vogue of sensation fiction was understood as beginning with Mrs. Maxwell's imitation of The Woman in White, the famous Lady Audley's Secret, which followed two years later. A significant fact which has apparently largely escaped attention is that Mrs. Maxwell's story was dedicated to Bulwer-Lytton, "in grateful acknowledgment of literary advice generously given." Moreover, Lord Lytton wrote Ouida an eight-page letter of congratulation upon one of her stories of high life. These circumstances, taken in connection with another, that the sensation novel almost invariably dealt with persons of station and wealth, suggest that if its mystery and melodrama derived something from Collins, it also harked back to the "fashionable novel" that Bulwer had begun in the twenties with Pelham. There can be little doubt that the mass of stories which occupied the book reviewers from early in the sixties for about a decade was little enough creditable to both its parents. Lady Audley's Secret, as a story still reprinted in cheap libraries, may serve as an example of the most durable, perhaps, of the lot. 
Lucy Graham is a beautiful light-haired, blue-eyed governess in the family of the village surgeon when first rich old Sir Michael Audley finds her. Rather unconvincingly, this excellent and wealthy man, who has never been in love, is passionately enamored of the pretty nobody and marries her. Lady Audley is not so innocent as she looks; previously she has wedded George Talboys, a dragoon, who, after spending his all upon her, has gone off to Australia to make a fortune. After three years of absence he is coming back with $£ 20,000$. At the time of Talboys's arrival in England, Lady Audley has been a bigamist only a few weeks. When George looks her up, she contrives by means of a trap to drop him into an old well and quite absurdly supposes him dead. He disappears mysteriously. Robert Audley, nephew to Sir Michael, and friend to George, sets about untangling the strange disappearance, and finally discovers Lady Audley's secret. That resolute lady desperately tries to burn him in an old inn where he is lodging. Next day, while Lady Audley is expecting tidings of his death, Robert confronts her with his proof before his uncle and discredits the doll-haired fiend. She is pronounced not quite sane and confined to a madhouse in Belgium, where she dies. The inferiority of this to The Woman in White and The Moonstone is especially apparent in two respects. Lady Audley is a crude amateur in crime, who attempts two very desperate murders with the incompetence of a school girl. She drops her first husband into the well and stays not to see if her business is done. She equally trusts to blind chance in the attempt on Robert Audley. In The Moonstone and in Jezebel's Daughter these things are looked after in a much more workmanlike way. Again, Mrs. Maxwell had little of the knack of melodramatic climax which makes the tense moments of The Moonstone or of Man and Wife memorable. No other test exhibits so plainly the 
unique genius of Collins as comparison with the best contemporaries who followed his path.

The themes of Lady Audley's Secret - bigamy, attempted murder, arson, and insanity - are stock themes, as The Quarterly reviewer indicated. There is, however, another trait of the book hardly less significant. This is a certain luxuriousness and lusciousness in description. Lady Audley's yellow hair, the richness of her dress, and the fittings of her boudoir are reiterated into distinctness. Relatively at least Mrs. Maxwell did not make these sketches offensive. But many of those who followed her did. Indeed this voluptuousness of description - partly a matter of prurience, partly desire to picture wealth and luxury to those who could know it only through the medium of fiction - is a characteristic of sensation novels second only to the predilection to crime. It finds one of its most egregious exemplifications in Ouida.

Louise Ramé, daughter of a French teacher, showed her bent of mind early by enlarging her name to De la Ramée. Ouida, the signature to some forty novels between 1863 and her death, was a childish mispronunciation of Louise. She began her literary career as a contributor to The New Monthly Magazine under Harrison Ainsworth, who seems to have been fittingly a kind of godfather in letters to her. Held in Bondage, her first novel, appeared in 1863 . Her manner of writing, it is said, never altered greatly, so that she outlived her popularity completely. For whatever the faults of public and of "commercial" novelists nowadays, the pretentious commonplace, the shoddy cynicism, and tinsel vulgarity on which Ouida built cannot any longer be mixed quite in her fashion. Strathmore, one of her earlier novels, is a typical sensation story illustrating the customary portrayal of "high life" by those who never saw it for those who never came into it except by the back stairs. 
Strathmore, a descendant of the Normans, with a family motto "Slay and Spare not," is impervious to love and desirous only of attaining fame as statesman and diplomat. $\mathrm{He}$ is obviously close kin to Bulwer's Devereux and Maltravers. Strathmore falls in with "the Vavasour," as Ouida likes to call her, - a reigning beauty whose origin is not known despite her being supposedly the wife of the Marquis of Vavasour and Vaux. Out of pure coquetry she makes a conquest of Strathmore, and they become lovers. This man, whose face reveals "power strangely blended with passion, repose with recklessness," and whose appearance within three pages is likened to that of Velasquez's political conspirators, Van Dyke's cavaliers, Charles Stuart, Catiline, and Strafford, becomes her slave. She persuades him to challenge his staunch friend Erroll, whom she has unsuccessfully wooed. Strathmore shoots Erroll dead; then, learning immediately of his mistress's perfidy, he casts her off, vowing revenge. He discovers the secret which the supposed Marquise has concealed - that she is not the wife but the mistress. He effects her ostracism from society. As reparation to Erroll he adopts his friend's daughter, Lucille, with whom as a middle-aged man he falls in love. Despite the protests of those who know how her father died, Strathmore weds the girl. "The Vavasour," who has been brought low, follows them to gain vengeance in her turn; but finally, having made Strathmore "suffer," she foregoes her revenge, realizing that it must fall mainly upon innocent Lucille. And so Strathmore lives happily ever after in the affection of the young wife whose father he murdered for a harlot.

So bald a summary indicates the background of society, the basis of the tale in adultery, the purely story-book characters of the persons involved, and the paltry penalty for murder; it does not indicate the ineffable silliness, ostentation, and vulgarity of the manner. A description of the 
heroine returned from a ball follows. "No toilette was so becoming as the azure negligé of softest Indian texture, with its profusion of gossamer lace about the arms and bosom, that she wore; no chaussure more bewitching than the slipper fantastically broidered with gold and pearls into which the foot she held out to the fire to warm was slipped; no sanctuary for that belle des belles fitter and more enticing than the dressing room, with its rose tendre hangings, its silver swinging lamps, its toilette-table shrouded in lace, its mirrors framed in Dresden, its jasper tazze filled with jewels, its gemmed vases full of flowers, its crystal carafes of perfumes and bouquets, its thousand things of luxury and grace. Here, perhaps, Marion, Lady Vavasour, looked her loveliest of all; and here she sat now, thinking, while the firelight shone on the dazzling whiteness of her skin, in the luminous depths of her eyes, and the shining unbound tresses of her hair, and on the diamond-studded circlet on her fair left hand that was the badge of her allegiance to one lord, and the signet of her title to reign, a Queen of Society, and a Marchioness of Vavasour and Vaux."

Ouida's men fit this atmosphere perfectly. Erroll is represented as wrapping about him "his seed-pearl embroidered and sable-lined dressing gown, dainty and lovely enough for Lady Millicent to wear." Strathmore reflects thus, "while perfuming his beard," about some of his women guests: "Pretty precisians, naughty as Messalina, who go to church like Marguerite to meditate on Faust." He and his companions are Don Juans one and all, who are bored by endless perfumed notes on tinted paper from ladies. It is the glory apparently of the Strathmores that they "had never loved the women who had slept innocently. on their hearts or laid out their pure lives within their keeping. The only passion that had ever roused them had been some fierce forbidden desire." The hero's friends agree that 
"everything virtuous is dull," and so amuse themselves largely by talking the nastiest scandal about the women they know in euphemistic vein. Strathmore upon hearing of Lady Vavasour's infidelities to her husband intimates that dishonor is a nobleman's general reward for bestowing his name and wealth upon a beautiful woman. "Dishonor? Fie, Strathmore," cried the Earl of Lechmere, a goodnatured fellow in the Coldstreams, "nobody uses those coarse, ugly dictionary words nowadays, except when he wants to get up a duel." Yet underneath this profusion of perfumes, jewels, "manillas" and cheap cynicism, we are supposed to believe that they are terrible fellows. Strathmore, as befits his "race," a favorite word with Ouida, "has something dangerous in his face." When he halts Lady Vavasour's runaway pair, he displays the dangerous passion that is in him by beating the horses he has stopped with the spirit and muscle of a horse-trainer. And he makes quite an exhibition of doing so, too, by first ostentatiously borrowing the whip from the helpless driver, and then, after he has thrashed the animals soundly, by carelessly and indifferently, as if he were bowing to an acquaintance on the Ride, lifting his hat to the woman he has rescued. She in turn stretches out to him "two delicate, ungloved, jeweled hands." $\mathrm{He}$ is deadly with a gun, also, and can hit the ruby in a lady's ring at a hundred yards. One character most solemnly assures another that he saw Strathmore perform the feat at St. Petersburg.

The essential explanation of all this is simple. James de la Pluche, often in petticoats, has found the market for "fashionable fax." Mudie's, Cawthorn \& Hutts', or The Library Company furnished for a guinea a year more of Ouida and her like than one could read. London, about the time she began, was the home of about two hundred and twenty periodicals - some of them, like Dickens's, to be 
had for twopence. Already cheap editions of the novelists at from one to six shillings the volume were customary. Historically sensationalism clearly represents a popular development in fiction in which the novel of mystery is crossed with that of fashionable life. The appeal to fear and the delineation of society in a peculiarly ignorant and vulgar fashion were inherent in conditions, because the appeal to fear is even a more nearly universal appeal than that of love between the sexes, and because none are so curious about Lady Audley and her boudoir or Strathmore and his perfumed beard as the bourgeois. The public of the sixties cared little for the castle in the Apennines. The adapting of its melodramatic terrors to local conditions and scenes, however, involved difficulties. The summary vengeance dealt out with the sword by a Byronic hero becomes stealthy murder, and the violence to her person always threatening Mrs. Radcliffe's heroine becomes adultery. The themes are the same; but the portrayal in a community where police decently enforce the civil law made difficult the task of the sensationalist.

There is something ludicrous in the seriousness with which current criticism viewed the orgy of sensation writing. This seriousness is comprehensible only when one bears in mind the smugness and sanctimoniousness of the Victorian middle-class public. To argue, as The Contemporary did, that Ouida, for instance, indicated any unusual corruption of society was to fly in the face of fact. Literary disease, sensation fiction, as it was written by Ouida and her like, certainly was - but it was a disease as inevitable as croup and measles are to children. It exhibits a replica of the conditions in the theater after Macready's retirement. Roughly, what Reade's melodrama and Burnand's burlesques were to Robertson and Gilbert, these sensation novels were to Walter Besant's, Blackmore's, and William Black's. 
They were not superseded by George Eliot's stories, nor Meredith's, nor Hardy's. Descendants of Mrs. Maxwell and Ouida, like Laura Jean Libby, may still be found at the corner of the railway bookstall, but they are certainly not read by the class corresponding to the readers of Strathmore or of The Interrupted Marriage. A couple of decades later than the appearance of Strathmore, Blackmore, Buchanan, Besant, and William Black had taught the public better.

In the early efforts of these writers, indeed, the waning sensational tendency is apparent. William Black, for instance, began as a novelist with Love or Marriage, ${ }^{1}$ a book he was accustomed later to speak of as "happily out of print." Blackmore's Clara Vaughan was regarded as an unequal sensation story, lighted up by attractive descriptions of scenery. Lorna Doone in 1869 and A Daughter of Heth in 1871 were extraordinarily popular, as were Besant and Rice's Ready Money Mortiboy and The Golden Butterfly in the early seventies. In such narratives as these the rigors and violence of the old sensationalism are giving way to sentiment. With the coming of these novelists sensation fiction in the Victorian sense seems to have slid down the scale to find a resting place in yellow backs, Penny Jupiters, and "family story papers" of blessed memory. The demand it answered is a perennial demand in modern society; a hundred years ago Byron and his followers were its exponents; half a century ago Dickens, Reade, and Collins devoted undoubted genius to it; to-day moving pictures are feeding the same demand on a scale and with an energy of which only the twentieth century is capable. It is obviously erroneous, however, to imply that it no longer gets printed. Until education and literary sophistication are far different from those democracy has hitherto produced, the phenomenal

1 Richard Garnett's notice of Black in N. D. of B. 
sellers will in most cases be of the sensational type. James Payn's Lost Sir Massingberd, which in 1864 is said to have increased the circulation of Chambers' Journal by 20,000 copies, Conan Doyle's Sherlock Holmes stories, Hornung's Raffles, Katherine Thurston's The Masquerader, exhibit the appeal as still undiminished in letters.

At the top of the sensation scale two generations ago stood the Dickensians, the men of genius whom the lesser folk imitated. With them the sensational, as has been said, was a definite creed of art. Understanding of this creed depends chiefly upon a knowledge of the market and the literary conditions under which they worked; their professed opinions of and preferences in narrative art; and the history of the method which grew up in prose fiction about the socalled Byronic hero. 


\section{CHAPTER II}

\section{Foreword}

\section{THE BACKGROUND OF SENSATIONALISM}

THE narrative methods of Dickens and his followers were determined to an unusual extent by matters involved in the extraordinary extension of the reading public that preceded and accompanied their generation. They were all professedly popular in aim, speaking for and to the class which the reform of 1832 had made a power in society. Dickens pointedly avowed such an object in the foreword to his first periodical. Reade, in revulsion from the labors of The Cloister and the Hearth, exclaimed: "I write for the public," and the public cares less for a dead lion than for a living ass." Doubtless this explains why he never again attempted historical romance upon the scale of his great medieval novel. Collins protests that a story of his will never obtain fair hearing until it comes to the popular edition - that is, until it is no longer listed exclusively as a three-volume novel at a guinea and a half. Their sensationalism was in part a result of the conditions under which they worked, as well as a cause for the extension of sensational fiction. Something like general recognition of these facts before 1870 is clearly indicated by Punch's parody titles for works of "The Sensational Novel Company." In the second quarter of the century trade in printed matter was revolutionized; cheap miscellanies and books became realities; a new race of publishers unlike the Murrays and Constables was springing up; popular writers were struggling with them for a fair share of greater profits than literature had ever before yielded. 
Some of these changes especially significant in the history of Victorian sensation novels were the rise of cheap books, the struggle especially of the novelists for a fair remuneration, the influence of miscellany and serial publication upon narrative form, and the attitude toward each other of novelist and public.

\section{The Rise of Cheap Books}

Behind the epoch of sensationalism which the school of Dickens dominated lies a long and complex chapter of trade revolution in bookmaking, in which Dickens's shilling pamphlet novels and cheap miscellanies played a leading part. Victorian sensationalism, which may briefly be defined as romance for the populace, could not really enjoy its innings until the machinery for disseminating cheap books had been rather highly developed. This cheapening of the product and multiplication of the agencies were the main trade phenomena from 1825 onward for about forty years. Specifically trade conditions reveal an almost unnoticed but compelling reason for the great length of the Victorian novel, especially that of the domestic type, and enable an understanding of the pronounced antipathy to. that kind of story expressed by Reade and Collins. The main influences for lower prices during these forty years were three: the shilling pamphlet novel, which reduced the current price of a full-length novel by one third; the circulating libraries, which, handling high-priced first editions by the hundreds, demanded discounts for buying in quantities; and the miscellanies, which, substantially relieved by a lighter paper tax, made novels by Dickens, Bulwer, Lever, and others of equal note available for six or seven shillings before the story was printed in book form.

It is not generally known that, as the demand for Waverley and its companion tales grew, Scott and his business associates imposed high and higher prices for his novels until 
the appearance of Kenilworth in 1821. The ponderous volumes which Constable issued, with their meadows of margin, had little in common with pocket editions and handbooks which enterprising publishers print in the twentieth century. Constable's and Murray's books were expensive products for the leisured and wealthy. Before Scott novels were hardly deemed worthy the costly permanent dress which such printers provided. Sir Walter was no less a gracefully negligent delineator of gallant heroes and heroines in distress than a shrewd man of business; and when Waverley proved capital both as romance and as business, he was diligent enough in attending to the business. Waverley, in 1814, sold for a guinea, a price attached to no other story of that year except Lady Morgan's O'Donnell. The Antiquary, two years later, was marked up to twenty-four shillings; Ivanhoe, in 1820, to thirty; Kenilworth in 1821, to thirty-one shillings sixpence. This final figure is important, inasmuch as for nearly half a century it remained the standard price for a first edition of almost any novelist who could achieve three volumes not too bad to print, and was finally crowded out of the market by cheaper forms only after about seventy years. Thus, an anomaly of printing, the three-decker at a guinea and a half, remained through the period of cheapening, a rather malign influence upon the structure of the Victorian novel, especially upon that mid-century favorite, the domestic story.

But in the same decade that this outrageous price was foisted upon book buyers, the demand for inexpensive reading matter of the superior sort was finding concrete expressions in such projects as Constable's Miscellany, and at the beginning of the next, in the various sheet publications of The Society for the Diffusion of Useful Knowledge. 1825 saw the beginning of both these activities. In that year Brougham's pamphlet, Observations on the Education of the 
People, ran through twenty editions. In the following year was effected the organization of The Society, with Brougham as president. At the same time Constable in Edinburgh was contemplating pamphlet publication of standard books which were to be brought out in weekly parts, three parts at a shilling each to constitute an entire work. "Printing and bookselling," he remarked in prophetic words, "as instruments for enlightening and entertaining humanity, and of course for making money, are as yet in their mere infancy." His pamphlets, he believed, would sell a million copies the issue. "Twelve volumes in a year, a half penny profit upon every copy which will make me richer than the possession of all the copyrights of all the quartos that ever were or will be hot pressed; twelve volumes so good that millions must wish to have them, and so cheap that every butcher's callant may have them if he pleases to let me tax him a sixpence a week." Despite the Edinburgh circle's evident amusement at Constable's sanguine ardor, the bookseller enlisted the support of Scott, Lockhart, and Maria Edgeworth, and received approbation of Sydney Smith. Knowing the number trade to be carried on extensively about London, he had communicated with his southern agents, not only explaining the plan, but requesting such information as they could furnish about the new branch of bookselling which he planned entering upon. The first number appeared January 6, 1827. On the 20th of the month he wrote to Scott that the miscellany "had met with a very considerable success." Indeed praise of the plan hád been so general and so generous as to warrant greater hopes than the depressed state of trade led him to expect. Already he had rivals. But Constable had been so long delayed in realizing his pet scheme that he was never to ascertain how much of the glory and profit which he expected it really offered. The common ruin that in- 
volved him and Sir Walter Scott was upon them. In July, 1827, the bookseller died, his end having been hastened by the trade calamity of that year. The Miscellany is less significant perhaps than Constable's prophetic vision of its possibilities.

Meanwhile, Brougham's society had been actively prosecuting its campaign. Colburn, Murray, and Knight had considered publishing for it; the organizers had restricted its objects, not without protest, strictly to that which its title implies. Conservative opinion generally deprecated the popular training which did not make religious instruction a prime consideration; but the leaders of the society itself resolved that neither religious nor political teaching came within their scope. The Penny Magazine, begun in 1832 , had a circulation of 200,000 copies before the year was out. So great was its success that the society planned a more ambitious Penny Encyclopedia, the articles for which were to be original contributions by the best experts in the realm. Ultimately eight volumes were to have been issued in penny numbers. When the sales rose to 75,000 copies, the society seemed likely to duplicate the success of the magazine; but poor planning, which made necessary the doubling of the price and of issues twice within three years, cut down the subscriptions to 20,000. Finally the encyclopedia was abandoned.

By the reform year, or a little later, there was not only an extensive trade in cheap periodical publications, but it was also forcing its way up the scale toward eminent respectability. How keenly Constable, as well as Brougham and his associates, had foreseen new conditions may be inferred from the computation of Knight, the society's publisher. In 1846 he declares: "Fourteen penny and half penny magazines, twelve economic and social journals, and thirty-seven weekly sheets forming separate books were to 
be found in the shops of many regular booksellers and on the counters of all small dealers in periodicals that had sprung up through the country. The cheapness was accomplished in some by pilfering every copyright work that came in their way. There were very few of these publications whose writers were paid for original articles upon a scale as liberal as that of the best reviews and magazines." The figures amply indicate the popularity of the society's methods; and the connection of eminent scholars such as contributed to the Penny Encyclopedia gave to cheap pamphlets designed for the populace a new standing in general esteem; so that the number trade, which Constable in 1825 found in the hands of inferior dealers, had lost nothing in cheapness, but had gained in extent and in caste.

The immediate ancestors of Pickwick and the pamphlet novel, however, were not Constable's Miscellany or the Encyclopedia and Biographical Dictionary of The Society for the Diffusion of Useful Knowledge. Constable, who was known to his familiars in the trade as the Czar of Muscovy, had a high and mighty way of speaking. Some of the dealers in number books whom he condescendingly dismisses as inferior traders were not inconsiderable men; there were notably Thomas Kelly, who was made Lord Mayor of London just before the accession of Victoria, after a highly successful career as a dealer in such works as Kelly's Family Bible, The Pilgrim's Progress, and Foxe's Book of Martyrs; and George Virtue, well known from about 1820 as a purveyor of religious publications. Virtue was one of those interested in Pierce Egan's famous Life in London or The Adventures of Tom and Jerry, which was illustrated by the two Cruikshanks. Tom and Jerry; appearing in shilling pamphlets in 1821, took the town by storm. In a stage version it was played simultaneously in ten theaters. The author himself declared that sixty-five different publications 
had been derived from his sketches. The occasional popularity of this sort of thing in the twenties is not less worth noting than another fact. Thackeray, writing of George Cruikshank after the illustrator's death, makes some remarks, based upon recollection it is true, of Egan's text: "As to the literary contents of the book they have passed sheer away. It was, most likely, not refined; nay, the chances are that it was absolutely vulgar. But it must have had some merit of its own, that is clear, for all London read it and went to see it in dramatic shape." Little flattering as Thackeray's recollection is, it reflects perhaps the esteem in which the man of letters was wont to regard an ephemeral "number book." Egan's pamphlet form of Tom and Jerry was the direct predecessor of Pickwick. Pickwick, and the tales of Dickens generally, represent the apotheosis of the number trade.

The story of the publication of this first great book of Dickens is well known; but some aspects of the price and publication in reference to commerce in fiction have received little or no attention. In 1836 Chapman \& Hall, then a young firm, desiring letter-press to accompany a series of sporting prints by Cruikshank, were casting about for a facile, clever writer to supply it. Not Dickens, but another, then a popular and highly regarded young author, was their first choice. Charles Whitehead, whose Autobiography of Jack Ketch in 1834 had been extremely popular, was first offered the work. Whitehead, however, doubted his ability to turn off creditable copy by contract, and recommended his friend Dickens as having the requisite facility. Dickens was then a reporter, about twenty-five years of age, earning five guineas a week, and as yet known only as the author of a volume of clever sketches. Inasmuch as he was planning to be married, the $£ 15$ offered for each monthly instalment was too tempting to be refused. The suicide of the 
illustrator before the second monthly part appeared left Dickens clearly master of the situation. The Posthumous Papers of the Pickwick Club created no immediate sensation, but by the time the fifteenth number appeared were selling to the extent of 40,000 copies. By that time it was apparent that there had been no such sensation in letters since the early Scotch novels. Chapman \& Hall, as the form of publication indicates, had aimed distinctly at the popular trade, and had luckily stumbled upon the writer who could appeal most powerfully to the entire reading public - the writer who was to be teacher, spokesman, and entertainer of the new democratic audience.

It has not been generally remarked that the shilling pamphlet novel was an important step in bringing down the price of novels to the consumer. In 1840 cheap reissues of popular stories were still twelve or fifteen years in the future; Scott's price was still in its heyday. A tale by Dickens or Thackeray would be issued in from eight to twenty monthly parts, at a total cost of not more than twenty shillings, or only two thirds as much as that of the standard threevolume story. The influence of the pamphlet novel upon prices did not pass unnoticed at the time. The reviewer of Pendennis in Fraser's in January, 1851, wrote: "Along with other things equally hallowed by prescriptive usage, the three-volume novel is clearly going out with the tide, being superseded by the periodical novel, a cheaper article. Pickwick is twice the length of Pelham and costs only two thirds as much. Long before free trade was dreamed of John Bull's constant impulse was to buy in the cheapest market. Even in case of that most superfluous of luxuries, fiction, he likes to get as much as he can for his money. Besides, it is so convenient to pay one's cash as it comes - in driblets." Clearly, then, the periodical pamphlet form of Dickens's stories and of Thackeray's tend automatically to prevent 
their entering the $31 \mathrm{~s} .6 \mathrm{~d}$. class on the very simple principle that goods offered for twenty shillings cannot well subsequently be made to bring $31 \mathrm{~s} .6 d .^{1}$ Of Dickens's books only one, an edition of Great Expectations, which was originally a serial in All the Year Round, is so listed in the Sampson Low Catalogue of 1864. The Sketches by Boz, Pickwick, Martin Chuzzlewit, Bleak House, Dombey \& Son, and David Copperfield in volume form are listed at twenty-one shillings. Vanity Fair brought the same amount. Pendennis and The Virginians, each in two volumes, brought twenty-six shillings. Twenty-one shillings or twenty-six, as the case may be, represents the original pamphlet price plus a charge for binding; but it is worth noting that the lower cost of the book is achieved without lowering the standard trade price of ten shillings sixpence for a volume of popular fiction.

The pamphlet novel served only a temporary need, and consequently ran only a brief, though brilliant, course. Dickens's public demanded that he follow the method of publication adopted in his first great book, and made it highly profitable for him to do so. All his novels, with the exception of those utilized for serials ${ }^{2}$ in miscellanies, appeared first in that form. Thackeray, when he felt that the time had come for an effort to lift himself out of hack periodical work, followed the precedent of Boz by bringing out all his five great novels except Esmond in shilling pamphlets; but, appealing to a narrower audience than his rival,

${ }^{1}$ It should be noted that the tendency was by no means uniform. A good many, perhaps the majority of, novels published in cheap miscellanies through the sixties were subsequently issued in three volumes at the guinea and a half rate. See end of the present chapter.

2 Oliver Twist appeared in Bentley's Miscellany; The Old Curiosity Shop and Barnaby Rudge in Master Humphrey's Clock; Hard Times in Household Words; and Great Expectations in All the Year Round; A Tale of Two Cities. The last tale was also printed separately in eight monthly parts. 
sold probably hardly one copy to Dickens's four. With the other great Victorians the cheap pamphlet novel is only sporadic, by reason mainly of the growing opportunity for fiction in the literary miscellanies. Others indeed did copy the pamphlet plan or some variation of it. Several novels of Trollope appeared so, as did Middlemarch in four instalments in 1872. The enterprising Smith's experiment with Trollope's Last Chronicle of Barsetshire in 1866 and 1867 practically represents the vanishing point of this most picturesque fashion of novel publication. In his autobiography, the author of The Last Chronicle records that "the shilling magazines had interfered greatly with the success of novels published in numbers without other accompanying matter. The public, finding that so much might he had for a shilling, in which a portion of one or more novels was always included, were unwilling to spend their money on the novel alone. Feeling that this had certainly become the case in reference to novels published in shilling parts, $\mathrm{Mr}$. Smith and I determined to make the experiment with sixpenny parts. If I remember right, the enterprise was not altogether successful."

Constable had foreseen that literature in cheap instalments was one of the great future possibilities of the publishing trade, and Pierce Egan had proved it even before Constable's plan matured, forty-five years before The Last Chronicle was ready for printing. Those forty odd years mark pretty definitely the vogue of the fashion. Earlier conditions hardly warranted belief in sales of the necessary magnitude for distinctly popular literature; later, so rapidly progressed the means of disseminating the kind of reading matter the public wanted, it was antiquated and no longer offered the best bargain for a shilling. But it served in its way the predominant purpose in current bookmaking, lower prices for popular reading matter. 
One feature of The Miscellany, as Constable originally planned it, was to have been Scott's novels in parts. As he had already greatly overstocked the market with highpriced editions, however, his London agents would not consent to cheap reissue. The popular edition which he projected was finally achieved by Cadell, who after the failure acquired the copyright of Scott's work for $£ 8500$. Constable's overproduction gave his successor no immediate course except a cheap reissue. Consequently, Cadell reprinted the Waverley novels in forty monthly volumes at five shillings each; and thus Scott became accessible for about one third the original price. The publishers also took a lesson from "the sixpenny science" publications and from Pickwick, by reissuing in 1842 in three forms - an expensive edition at twenty-eight shillings the volume; a second in twenty-five monthly volumes at four shillings each; and a third in weekly parts, ninepence the part, the complete novels at two shillings each. Curwen, whose figures are derived from James Mylne, one of the executors of Cadell's estate, gives the circulation of Scott's work from the time that publisher acquired the copyright to his death in 1849 as follows: of the novels 78,270 sets; of the verse 41,340 ; of the prose works 8260 ; of the weekly instalments of the novels he issued $7,115,197 ; 674,955$ of the verse; and 269,406 of the prose. ${ }^{1}$ These republications of Scott were among the earliest attempts systematically to cheapen the price of fiction. Mr. Morton, ${ }^{2}$ in searching for such efforts, found previously only one by Smith, Elder \& Company in 1833 which they abandoned in less than a year.

The extensive reprinting of popular favorites in cheap form was delayed for ten or fifteen years after Cadell's

1 Curwen, History of the Booksellers, p. 138.

2 Nation (N. Y.), April 3, 1913. 
experiment with Scott's work in weekly sheets. Colburn, who owned the copyrights of Lady Morgan, Godwin, Theodore Hook, and Bulwer-Lytton, took a hand as innovator in cheaper books when, in 1835, he began reissuing his Library of Standard Novelists - stories by those favorites at a reduced rate. There was a cheap edition of Dickens beginning in 1847, in three series, published by Chapman \& Hall and Bradbury \& Evans in three halfpenny weekly numbers. Bulwer and Disraeli, whose early novels had remained among the exclusives in some cases for twentyfive or thirty years, suffered startling reductions. In 1863 Bulwer was procurable in volumes selling for three shillings sixpence and also in two and six volumes; Disraeli could be had either at two and six the volume, or in cheaper shilling books. By that date, in fact, almost all novels written before 1855 which had enjoyed any considerable popularity could be bought for not more than three shillings sixpence. The high price imposed by Scott and his associates still persisted for first editions through the period of cheapening; but with three forms of issue thus evolved serial publication in a miscellany, three volumes at a guinea and a half, and finally single volumes at three and six - the tendency was to shorten the interval between the threevolume and the cheap issue until it was generally about a year.

The circulating library was also a powerful influence for cheaper novels. During the fifties and sixties the periodicals abound in advertisements of this institution, with Mudie's at the head of the list. Others that based a title to respectability upon wide advertising were Smith \& Sons, The English and Foreign, Cawthorn \& Hutts, The Library Company, Booth's United Libraries, Coome's, and Mitchell's Royal. Mudie charged one guinea a year for class A subscription, and half as much for class B. From his adver- 
tising, it seems to have been customary for several families to purchase one subscription jointly. $\mathrm{He}$ also regularly sold out used copies of expensive books at bargain prices. The standard trade charge was still from ten to twelve shillings; Mudie's bargain sales reduced them to four or six. It is generally intimated of the circulating libraries that the three-volume novel at 31 and 6 produced their great profits, and that they reciprocated by driving the three-decker out of the market.

Something of the power that they exercised upon the trade may be gathered from the scale on which they worked. Mudie had as many as 25,000 subscribers scattered through the kingdom, and bought of popular and high-priced books on a scale to correspond with his subscription list. In 1860, when he was attacked for the censorship he exercised in selecting books for the library in an article entitled Literature at Nurse, he replied in The Athenaeum with a short letter, at the end of which he enumerated his purchases since January, 1858. In less than three years he had added to Mudie's 87,210 volumes of history and biography, 50,572 of travel and adventure, 165,445 of fiction, 87,856 of science, religion, and miscellaneous reviews. The total is 391,083 . He had 2400 copies of the third and fourth volumes of Macaulay's England, 2000 of Livingston's Travels, and traded in what his advertisements called "the higher grade of fiction" on a like wholesale plan. Of the three-volume edition of Adam Bede, he took 1500 copies; of the later two-volume edition at twelve shillings he took 250 upon publication, 250 more within a week, and 400 additional within two months. He could do much for a book by advertising that his library had on hand a hundred or a thousand copies, the more so with the Victorian public because he was a devout man, who wrote hymns, and aspired to exercise a censorship of letters. He was quite within the truth in the 
letter just mentioned when he cites the gigantic lists of his buyings as evidence of the popular confidence in his standards of inclusion. Mrs. Oliphant's remark that at the beginning of her career recognition by Mudie of a book of hers seemed like recognition from Heaven becomes intelligible enough.

- Mudie naturally waged war with conservative and highpriced publishers in two ways; he sought reductions for buying wholesale, and he fought for earlier reissues of popular novels in cheap form. The Blackwoods, for instance, were stoutly resisting his demands for discounts during the fifties. In $1858 \mathrm{John}$ Blackwood was prepared to give Mudie 10 per cent off on purchases of five hundred copies, but thought his customer ought to be so favored only when the purchase involved a risk. Mudie found a leverage within the trade itself, however; for before the middle of the century new conditions of the literary market had raised a new tribe of publishers of a different stamp from the Murrays and Constables. In the newer trade, which specialized in fiction, Colburn and Bentley were leaders. We get an interesting glimpse of conditions in the London market just before mid-century from an evidently well-informed writer for Fraser's in March, 1847. "All poems," he declares, "all works on morals or metaphysics are, with scarcely any exception, without price. Novels, when by popular authors, are paid for at a price varying from $£ 100$ to $£ 500$, and in one or two instances to $£ 1500$; when by authors unknown as novelists but tolerably known in other departments, they are at the publisher's risk and half profits; when by clergymen, gentlemen of a literary turn, titled ladies, or aspiring clerks, the publisher either consents to print them at his own risk and profits, or else demands a sum of money varying from $£ 50$ to $£ 200$. A first novel is never paid for. One 
publisher ${ }^{1}$ is known to publish gratuitously any novel not too wretched, with the understanding that if it succeeds (what a latitude!) the author shall be paid something (another!) for his second novel. In this way he is enabled to keep up a running fire of novels, scarcely one of which is ever paid for."

Trollope's The Way We Live Now, a satire the nature of which the title indicates, presents in Lady Carbury one of these aspiring literary ladies, and shows amusingly enough what became of her three-volume novel The Wheel of Fortune, with which she followed up her historical study Criminal Queens. The novel must, of course, be in three volumes, and each volume must contain three hundred pages. "Don't let it end unhappily," Mr. Loiter, her publisher, exhorts her, "because though people like it in a play, they hate it in a book, and whatever you do, Lady Carbury, don't be historical. Your historical novel, Lady Carbury, isn't worth a - straw," says Trollope, applying to his fictitious aspirant the words which one of the advisers of Smith, the energetic proprietor of The Cornhill, had used to him when he submitted a historical romance. Having ground out her nine hundred pages in accordance with Mr. Loiter's advice, Lady Carbury turned over to him the manuscript of The Wheel of Fortune. He shocked her by carelessly tossing it into a great sack beneath the counter - a sack as he calmly explained which was waiting to be filled with other hopeful three-deckers like her own before being sent to the company's reader as common freight. So few manuscripts, Mr. Loiter observes, would ever repay the expense of postage!

Lady Carbury's experience is probably not exaggerated; it is indeed singularly like her creator's before he had mas-

1 Probably Henry Colburn whom Fraser's hated as proprietor of The New Monthly, as the publisher of fashionable novels, and as a "progressive" man of business. Colburn was an adept in advertising his books. 
tered the trick of baking his tarts to the public taste. Trollope came of a stock prolific in novel-making; for his mother was one of the favorites of the generation that preceded his; his brother and sister both produced fiction good enough for publication. His own early attempts both Anthony and his folk thought to be "an unfortunate aggravation of the family disease." His mother induced the publisher Newby to take his first story, The Macdermots, and to give him half profits. There were no profits - a circumstance which Trollope declares occasioned him no surprise; there were not more than fifty sales, he supposes. The Kellys and O'Kellys, published a year later, in 1848, by Colburn under the same half-profit agrement, was finally described by The Times as resembling a leg of mutton - "substantial fare, - good, but a little coarse." "Even that," says Trollope, "did not sell the book." Colburn printed 375 copies and sold 140 - so few that the book failed to pay for the cost of publication by $£ 63,10$ shillings, $1 \frac{1}{2}$ pence. "The sale has been, I regret to say, so small that the loss upon the publication is very considerable," - so Colburn wrote to Trollope, - "and it appears clear to me that although in consequence of the great number of novels that are published, the sale of each, with some few exceptions, must be small, yet it is evident that readers do not like novels on Irish subjects as well as on others. Thus you will perceive it is impossible for me to give any encouragement to you in novel-writing." In slightly less than ten years, four novels and a play The Macdermots, The Kellys and O'Kellys, La Vendée, The Warden, and the drama, The Noble Jilt, the plot of which Trollope later utilized in Can You Forgive Her? brought the writer all told $£ 40$, a wage, as the novelist remarks, that he might easily have bettered at stone-breaking. But the chronicler of Barsetshire was stout of heart and did not pine even when "half profits" represented only a deficit. 
Many, like Trollope, had the itch for print, but few had his perseverance. Their indulgence of the malady seems to have provided the leverage mentioned previously.

At all events the Newbys and Colburns, whose fiction often cost them little save for printing and advertising, were glad on many counts to sell great batches of novels to Mudie's at greatly reduced rates; for thus they made sales of a sort of doubtfully marketable goods and at the same time gained for them the valuable stamp of Mudie's approval - Mudie's recognition of a book by putting it on his list might well seem to any struggling novelist less determined than Anthony Trollope almost like "recognition from Heaven." Mudie, too, asserts, in his reply to George Moore's Literature at Nurse, that he took pride in anticipating the demand for fiction. If, as Mrs. Oliphant surmises, he sometimes secured great batches from Tinsley, Colburn, and Newby at half price, his zest for right guessing is comprehensible on various grounds. Conservative publishers, therefore, like the Blackwoods, had the alternative of compromising with the library leviathans or sacrificing the sale of whole editions. Yet, while Mudie's personal influence was certainly one of the strongest influences in bringing the price of fiction down, it is clear that the tendency toward cheaper reading matter was far too extensive to be greatly retarded or accelerated by a single influence, no matter how powerful. The circulating library was a power certainly, but there were others equally important.

The novel at a guinea and a half was an unconscionable time dying, however; for although its fate was apparent at the time Pendennis was appearing, it did not entirely disappear until the nineties. The means of disseminating cheap literature by 1860 , however, were keeping its sales down. The Tinsley Brothers, publishers of the unusually successful Lady Audley's Secret, considered the sale of three editions 
of 500 copies each within eight or ten days a very considerable piece of business. If The Sixpenny Magazine, in which Mrs. Maxwell's story had previously appeared serially, could compare in circulation with such contemporaries as The Cornhill and All the Year Round, there were about sixty purchasers of the periodical form for one who bought the three volumes. This reactionary bookseller's device, more than the fabled leisurely lives of our grandparents, accounts for the long-drawn-out novel of 900 or 1000 pages. Lady Carbury, as we have seen, understood that a certain bulk was necessary for The Wheel of Fortune. Nor was this mere satire on Trollope's part. Clearly a public that paid. a guinea and a half had justification for feeling defrauded by a thin book. Besant says the 100,000-word novel was esteemed "short measure." The profession indeed understood achievement of the three-volume novel to be a condition of first-rate success. ${ }^{1}$ Hence in large part the dilution and divagation of the ordinary Victorian novel - the endless political disquisition of Disraeli, the pompous inanity of young Bulwer's reflections on things in general, the curiously elaborate descriptive effects of the Dickens of the forties, and the pedestrianism of Trollope, who flatly declares his principle of stretching his story to the size of his canvas. All more or less directly are connected with the famous price of thirty-one and six. Practically this price did more than can be accurately estimated to retard and distort in English fiction formal narrative art as such. To borrow Mr. Saintsbury's picturesque figure, it too often made the three-decker a sandwich with a sawdust filling. The burden

"Trollope again is authority for the statement that "short novels" had not generally been successful. Dickens gives wholesome advice to an aspirant to his columns, implying that the three-volume story is a test of a writer's ability that one should not attempt at first. One should begin more modestly, as he says he had done in his time. 
of length which it imposed, however, was more agreeable to the favorite domestic style of novel than to the novel of incident. The writer who accepted the canons of domestic fiction - that is, character and humor as more to be desired than plot - did not find the three volumes of three hundred pages each altogether unmanageable. The story of adventure, however, fared comparatively ill. How the fashion affected dramatic fiction is indicated subsequently. All this, however, gives definite meaning to the oft-repeated complaints of Wilkie Collins about novels which "blunder continually in telling a story" and Reade's fiery invective against Trollope and George Eliot for using, "after their kind," many words.

Cheap miscellanies were no less powerful than the shilling pamphlet or the circulating library in making fiction cheaper. The first group of literary miscellanies, Blackwood's, Fraser's, and Colburn's New Monthly, affected the reduction very slightly if at all. 'From 1840 to 1850 , when they began printing serial novels systematically, the number of instalments varied from four to ten or twelve. A four-instalment story could hardly be printed otherwise than in a single volume; a twelve-instalment story would make two volumes or three. Inasmuch as these periodicals sold at half crown the copy, there was no notable variation of the general trade price of 10 and 6 the volume. The bargain here was comprised in the additional matter, which was often delightful and notable; for it might include Wilson's essays, Maginn's poems, or Thackeray's burlesques. The magazines lower in the scale, however, achieved very notable reductions. In the two hundred and twenty periodicals which, according to Knight, were printed in London during the sixties, there must have been many modeled on and only less excellent than Dickens's twopenny weeklies. From the figures cited elsewhere the extent of their circulation may be guessed. 
In the instance of Dickens's weeklies, the fiction thus put before the multitude was often the work of the best novelists. Household Words and All the Year Round introduced to the public in the first printed form North and South, Hard Times, The Dead Secret, A Tale of Two Cities, The Woman in White, A Strange Story, and Hard Cash. No miscellany could boast a group of narrative contributors superior to Mrs. Gaskell, Wilkie Collins, Dickens, Bulwer-Lytton, and Charles Reade. At the end of the review of the twentyfour sensation stories in The Quarterly article previously mentioned, the writer subjoins a table to make clear how readily accessible cheap periodicals were making sensational tales in the early sixties. According to this computation, while The Woman in White, No Name, Great Expectations, Mrs. Wood's Verner's Pride, and Mrs. Maxwell's Lady Audley's Secret bring $31 s$. 6d. in three-volume form, the first four, all of which appeared first in Dickens's All the Year Round, cost respectively in periodical form $4 s .4 d$., 6s. 8d., 6s. 8d., and 4s. 4d. Mrs. Wood's story in Once a Week cost 8s., and Mrs. Maxwell's in The Sixpenny Magazine 6s. Thus the instalment plan of publishing and of paying reduced the cost of novels to a mere fraction of the price set by Constable and Scott.

In something less than forty years from the time of Constable's Miscellany, the book trade was revolutionized to meet new conditions under which practically every one was a reader of one sort of printed matter or another. Shilling pamphlet novel, circulating library, and long-delayed cheap miscellany united to end the régime of the picturesque old monarchs of the trade like Murray and Constable, and to establish in their place a new tribe of Newbys and Tinsleys. By the sixties the connection between cheap miscellanies and sensational fiction was a literary commonplace. By that time the millions seeking romantic diversion from the 
humdrum life of the industrial epoch existed; and the twopenny weekly had brought it within the reach of all.

\section{The Novelist as Wage Earner}

By 1840 it appears from the generally increased dependence of the magazines upon serial fiction, as well as from Dickens's experience with Master Humphrey's Clock, that the vogue of the serial novel is firmly established. It may be something of a parvenu yet, but those engaged either in writing it or in selling it begin to see visions of the profits it offers. From the writer's point of view there are at this juncture two problems to be solved - the first is to get a story which promises to be popular before as much of the reading public as possible, for the three-decker at 31 shillings will reach only the wealthy or well-to-do subscribers to the circulating libraries; the second is to gain a remuneration commensurate with the sales. The famous publishers in the early part of the century - men like Constable, Murray, and Blackwood - were not only men of business but of ideals, who knew that their trade was more than mere commerce. They felt - and rather ostentatiously vaunted - their dignity and responsibility to public and to authors. They were patrons of the arts, and not less notable persons than the writers for whom they held the purse-strings. "You will be gradually from this time rising into the higher duties of cultivating young men of genius of the day," John Murray wrote to the elder Blackwood just before Maga began. Lockhart, then a youngster in Edinburgh, relates his wonder at the "gentleman-like appearance" and manner of Constable. His unsophistication greatly amused Scott, whom he asked to identify the imposing personage. "Oh!" he reports Sir Walter as saying, "are you so green as not to know that Constable long since dubbed himself The Czar of Muscovy, John Murray The Emperor of the West, and 
Longman and his string of partners The Divan?" "By God!" the Czar of Muscovy used to say in his most regal moments - "I am all but the author of the Waverley novels."

Leaving for the present the old monarchs of the trade, one cannot but perceive that when stories begin to sell as the Waverley novels or Pickwick sold, there must shortly be a readjustment of the novelist's remuneration. The conflict between writer and publisher is not to be thought of as the result of niggardliness among publishers. Those closest to the trade had little definite notion of what was coming. Lockhart's story of Constable's projected miscellany shows clearly enough that the Edinburgh circle thought it partly - perhaps largely - a bookseller's vagary. Literary conditions, from the opening of the century, were undergoing extraordinary changes, and the publisher's power arbitrarily to regulate and apportion the supply of books or the rewards for writers was passing. Chapman \& Hall were probably quite as surprised as the young writer whom they paid $£ 15$ an instalment when the fifteenth pamphlet of Pickwick reached a sale of 40,000 copies. At most they expected to find another Pierce'Egan. With the old regal attitude of Murray and Constable a thing of yesterday, publishers could hardly at once recognize the sweeping modifications that mere novels and novelists - not very highly esteemed in the old scheme of book-trading - were about to effect. The times when $£ 1000$ represented a fair price for a novel by a competent and tolerably popular workman were gone. ${ }^{1}$

The career of Dickens exhibits the working out of these

${ }^{1}$ Scott, of course, is an exception for many reasons. One of the popular men of letters long before he wrote novels, he also was practical proprietor of a printing house. $£ 1000$ represented a high figure for fiction before Dickens; see scale of prices below. 
problems. Indeed, the significance of his fight for profits was hardly less great to the business of fiction-writing than was his success as a story-teller in perpetuating the vogue of fiction. His contribution in making the novelist the great literary wage earner has probably never been sufficiently emphasized.

The needy newspaper man who was overjoyed at the prospect of $£ 15$ for each number of Pickwick found himself suddenly famous; but the means of securing a fair share of the earnings was anything but easy. The agreement with Chapman \& Hall stipulated twenty numbers of Pickwick at the rate mentioned, with a further understanding that, in case of success, Dickens was to receive further payment in proportion to the sales. The publishers, who ultimately made over to him from $£ 2500^{1}$ to $£ 3000$, acknowledged that they had cleared something like $£ 14,000$. The figures are only approximate; but the writer received only from 17 to 20 per cent of the profits on one of the most popular books of the century. Worse yet, enterprising publishers had discovered before he knew it himself that Pickwick promised a popularity for its writer greater than that of any living man of letters. Bentley, then planning a literary miscellany on a more popular plan than the Magas and Reginas, saw in Dickens the right man to be his editor and leading contributor; and just before the appearance of the sixth number of Pickwick bound him to a contract to edit the new periodical. He was to supply a serial to begin with the first number, and to furnish Bentley also with two more novels, one of which was to appear within a given time. When the new Bentley's Miscellany began with Oliver Twist for a leading attraction, Dickens found himself facing the impossible task of carrying on three stories at once. Pickwick Papers were still being issued by Chapman \& Hall,

${ }^{1}$ Forster's Life of Dickens, Chapman and Hall, 1872, vol. 1, p. 124. 
and the third novel, Barnaby Rudge, ${ }_{2}$ according to contract, had to be in active preparation. More than this, he now realized that his bargain was financially bad also, though how bad he was not quite aware, so loose had his business methods been. Bentley had been right in his choice of editor, for Oliver Twist struck public fancy only less favorably than Pickwick - a circumstance which added to the writer's desperation. How hopeless the situation appeared to him, his letter to John Forster testified." "The immense profits which Oliver has realized to its publisher and is still realizing; the paltry, wretched, miserable sum it brought me (not equal to what is every day paid for a novel that sells fifteen hundred copies at most); the recollection of this, and the consciousness that I have still the slavery and drudgery of another work on the same journeyman terms; the consciousness that my books are enriching everybody connected with them but myself - and that I with such a popularity as I have acquired, am struggling in old toils, and wasting my energies in the very height and freshness of my fame, and the best part of my life, to fill the pockets of others, while for those who are nearest and dearest to me I can realize little more than a genteel subsistence! all this puts me out of heart and spirits." Whatever the merits of the case, breaking with Bentley was inevitable. When Oliver Twist was completed in The Miscellany, Dickens retired from the editorship; and was absolved from his contract as to Barnaby Rudge upon payment of $£ 2250$ for the copyright and remainders of Oliver. $^{3}$ The readjustment

1 Apparently he was to receive about $£ 500$ for Barnaby. Forster, p. 114.

2 Forster, pp. 139-140 (vol. 1).

3 Dickens had a similar lesson in the high-handed methods of publishers in dealing with copyrights from Macrone, a small publisher who acquired the rights to the Sketches of Boz for $£ 150$. Upon the 
of the difficulty concerning Pickwick looked forward to a common form of agreement subsequently between novelist and publisher by which publisher gained only a temporary control of the copyright. The new arrangement with Chapman \& Hall guaranteed to Dickens one third interest in the copyright of that book after five years, upon condition of his producing another novel (Nicholas Nickleby) of the same length.

His hard experience had taught him to make the most of his opportunity; and to it, in part at least, is due his journalistic work after 1840 . There were three of these popular journals which built their hopes upon. his personal popularity - Master Humphrey's Clock, begun in 1840 and discontinued just before the first visit to America; Household Words, which ran from March 1850 to May 1859; and All the Year Round, which first appeared in April 1859, and which he edited to the time of his death. The first of these was intended to relieve the drain consequent upon novel-writing by affording the opportunity for less consecutive and sustained composition, and not less to guarantee to the writer the profits of his popularity. But finding immediately that his public did not greatly care for the desultory description of journal he had projected in Master Humphrey's Clock, he was obliged to give them fiction in the form of The Old Curiosity Shop to maintain his venture. He tried to keep his journals peculiarly his own; he wished them to provide a profitable market for other composition than three-volume novels. The most profitable - All the Year Round - which by July of the year it was established had paid all debts incurred and earned $£ 500^{1}$ - depended largely upon three-

success of Pickwick, Macrone designed reissuing the book without consulting the author, and extracted about $£ 2000$ from Dickens and Chapman \& Hall for copyright. - Forster, pp. 100-102.

1 Forster, vol. 3, p. 216. 
volume novels. The new journal, opening with $A$ Tale of Two Cities, later also brought out in the first form Great Expectations. Wilkie Collins contributed The Woman in White, No Name, and The Moonstone. Charles Reade contributed Hard Cash; Bulwer-Lytton, A Strange Story; Mrs. Gaskell, North and South.

How industriously $\mathrm{Boz}$ was employing all the resources of the new market for popular literature which existed in the middle of the century will appear in the handling of $A$ Tale of Two Cities. His old public steadily demanding his novels in the original pamphlet form, A Tale of Two Cities, which gave All the Year Round a propitious start, appeared in two serial forms as well as in the volume form. ${ }^{1}$

Even though he had forced what seemed a fair remuneration and had found periodical work profitable, Dickens decided in 1844 to make another change in his printing. As a result of a disagreement with Chapman \& Hall about A Christmas Carol, he made over to Bradbury \& Evans for $£ 2800$ a fourth interest in whatever he might write during the ensuing eight years; there was also a stipulation as to a possible periodical of which Dickens "might be only partially editor and author," ${ }^{2}$ in which case his proprietorship of copyrights and profits was to be two thirds instead of three fourths. This agreement, after one renewal, terminated in 1859, when Dickens returned to his original publishers, Chapman \& Hall; the agreement with them invariably calling for the reversion of copyright after a term of yearrs. These arrangements seem to have set precedents which

1 Other stories, like The Old Curiosity Shop, Barnaby Rudge, Hard Times, and Great Expectations, which were originally magazine serials, were printed in only two forms - as serials and as volumes; aside from these the first form of his major novels was that of the monthly shilling pamphlet.

2 Forster, vol. 2, ch. 3, p. 66. Chapman \& Hall Edition, 1873. 
the favorites among Victorian novelists could follow; and one tolerably sure of a large audience would sell copyrights on Dickens's plan. George Eliot, as noted elsewhere, preferred to sell Romola for $£ 7000$ with a reversion of copyright rather than accept $£ 10,000$ for outright sale. And thus the popular story-teller had become powerful enough to sell at a far higher price than any other man of letters, and yet preserve a profitable interest in the product. Shortly after the middle of the century, therefore, the novelist had three distinct forms of publication - the shilling pamphlet, which gave way to the magazine serial, the high-priced three-volume edition for libraries and the wealthy, traditional reading class, and finally the popular priced reprint at three shillings sixpence or less, which was issued after the three-volume edition began to flag. Dickens by 1850 had explored the resources of the new market; the lucky venture, Pickwick, had launched the number trade on a wave of unparalleled prosperity; hard bargains with the publishers had influenced him toward journalism, and various experiments in method of publishing led him to adopt that of reversionary copyrights.

The novelist's remuneration went up with a bound. From early in the century England had been paying better for periodical work than any other country in Europe; ${ }^{1}$ the quarterlies were giving from sixteen to twenty guineas a sheet $^{2}$ to ordinary contributors. The Revue des Deux Mondes, when Nisard, De Vigny, Alfred de Musset, and Sainte-Beuve were among its contributors, paid its record price of 250 francs a sheet to George Sand. An industrious man of letters in England could earn from $£ 250$ to $£ 1000$ a year by periodical work or novel-writing. According to Murray's scheme, when

${ }^{1}$ Fraser's, March, 1847, p. 286 ff., "The Conditions of Authors in England, Germany, and France."

${ }^{2}$ The Edinburgh earlier in the century gave ten. 
a partner in Blackwood's Magazine, Wilson and Lockhart were to divide $£ 500$ for the editorship, in addition to which they were to be paid for whatever they wrote. De Quincey when in Edinburgh was earning about $£ 300$ by contributions to the same miscellany. Thackeray, after a year's work for the magazines, and so while still obscure, was probably doing a little better. Bulwer-Lytton, just before his marriage, when he was already considered a rising novelist, told his mother that by unremitting literary labor he could turn about $£ 1000$ a year.

Before 1830 the novelist's remuneration is considerably higher than that of other men of letters; but the figures become paltry beside those for fiction from the forties onward. Earlier than 1840 it was an exceptional novel that brought $£ 1000 .^{1}$ Constable refused Scott that sum for Waverley, a story by a practiced and favorite man of letters. More significant of the general scale are the prices paid Jane Austen and Susan Ferrier. Blackwood ga ve Miss Ferrier $£ 150$ for Marriage, a first novel; and $£ 1000$ for Inheritance, rather than lose it when the writer refused his offer of $£ 500$. Cadell's $£ 1700$ for the same novelist's Destiny was an unusual price. In 1829, Galt, who had some reputation as a contributor to Blackwood's, could get only £300 from Colburn for a novel. Lockhart was glad to get the same amount for Adam Blair, with conditional promise of $£ 200$ additional should the book go into a second edition; for Reginald Dalton he received $£ 1000$. The four novels of Jane Austen published before her death brought her about $£ 700$.

If these figures are large relatively in comparison with those for periodical writers, they are small in comparison with those for the popular novelist from the time of Pickwick onward. Bulwer-Lytton received $£ 500$ for Pelham, $£ 800$ for Disowned, $£ 1500$ for Devereux, $£ 3000$ each for the

1 Tom Jones brought $\mathfrak{1 6 0 0}$; The Italian $£ 800$. 
Caxton series from the Blackwoods with reversion of copyright. Dickens, after several years of authorship, found that $£ 200$ for a monthly instalment, or $£ 4000$ for a twentypart story, did not bring all the profit he might reasonably expect from his popularity. Thackeray was promised £350 by the owners of The Cornhill Magazine for each number of a serial story, the profits of the cheap edition to be divided, those on the serial and first book form going to the purchasers, Smith, Elder \& Co. The same novelist estimated that his greater stories brought him from $£ 2000$ to $£ 6000$ each. The receipts from Esmond and Vanity Fair he estimated at the lower figure; those from The Newcomes at $£ 4000$, and from The Virginians at $£ 6000$. Anthony Trollope, after a hard apprenticeship and a very unprofitable one, averaged about $£ 1700$ each for ten novels published from 1859 to 1864 . Dickens received somewhere from $£ 2500$ to $£ 3000$ for Pickwick, $£ 3000$ each for Barnaby Rudge and Nicholas Nickleby for limited sale of copyright; $£ 200$ for each monthly number of Martin Chuzzlewit; and then on account of a disagreement over sales made the contract with Bradbury \& Evans which he hoped would gain him a larger share of the profits. George Eliot, whose price had mounted to $£ 1000$ by the time of Felix Holt, seems to have won the record price for Romola, for which the owners of The Cornhill Magazine offered $£ 10,000$. The author preferred to sell for $£ 7000$ with reversion of copyright.

By mid-century the transformation was practically complete. Democracy was triumphant in letters as in society; and in consequence magazines and novels were the favorite literary forms. The novelist had become the great literary wage earner; the publisher is no longer the despot or the patron of letters, with power arbitrarily to apportion the supply of books or the remuneration of popular writers. Imagine Chapman \& Hall or Smith ejaculating that they 
are all but authors of Pickwick or Romola. Not less conscientious perhaps than his predecessor, the publisher becomes primarily a man of business. In the new scale of winnings the distribution was not only partial to light literature, but also was often undiscriminating among the novelists themselves. Over against the soundness of the change as indicated by Dickens's earnings, or Thackeray's, or George Eliot's must be placed the very dissimilar experiences of say Meredith and Gissing. Undoubtedly, too, though the freer play of demand and supply was mainly wholesome, the changes increased the itch for print, and, abetted by the half-profits system, rendered attainment easy. This aspect of the new market is strikingly illustrated in one of the escapades of the notorious Maginn. For Fraser's Maginn reviewed Berkeley Castle, a worthless threevolume "fashionable" novel issued by Bentley in 1836. The book was written by Grantley Berkeley, who, taking advantage of the fashionable craze, narrated a not very distinguished or creditable family story. Inspired by whisky, Maginn dashed off a review of the novelist's effrontery, the personalities of which were quite as outrageous as the tone of the wretched story. The enraged author sought the publisher and administered a beating from which Fraser never recovered. Upon Maginn's acknowledging the article as his, a duel followed between author and reviewer.

The novelist is likely to be a trifle deprecatory of his craft or even a little lacking in self-respect at the same time that he is exhilarated by the sense of new opportunity. Reade used to be fond of saying Nummus aliit litteras. In a new preface to Pelham, which reveals vivid recollection of the attacks by the Fraserian apaches, Bulwer wrote: "The Public is the only critic that has no motive or no interest in underestimating an author." In characteristic 
magniloquence he proceeds: The writer's "world is a mighty circle of which envy and enmity can penetrate but a petty segment." The novelist, therefore, went about his business with the sobriety and industry of a professional man bent on getting on; but he is wont to be surprised a little at himself and at the public which takes him so seriously. His position as a man of letters, he is aware, has in it much that is anomalous. The traditional odium attaching to professional writing and to novel-writing in particular explains Thackeray's occasional grimace, or Reade's occasional and inconsistent protestation of capability for better things than the spinning of profitable lies. In soliciting contributions to The Cornhill, Thackeray wrote to Trollope: "I often say I am like the pastry-cook and don't care for the tarts, but prefer bread and cheese; but the public love the tarts (luckily for us) and we must bake and sell them." Reade was accustomed to eulogize the Waverley romances with the fervor of a reviewer of the twenties, and to envy "Sir Walter his first innings in this land of leal." Trollope, a frank journeyman, confesses "that my first object in tąking to literature as a profession was that which is common to the barrister when he goes to the bar, and the baker when he sets up his oven: I wished to make an income on which I and those belonging to me might live in comfort." A main difference between the Victorian novelist and the novelist of an earlier time is that the former has become a laborer worthy of his hire, and is a little surprised at the circumstance. He feels that he ought to take himself seriously; and yet, mindful of the nature and reputation of novels, cannot in his heart always quite do so. "He knows the formula "open sesame," but half suspects the magic to be illusory. Consequently he alternately describes himself as the fabricator of "profitable lies," or proclaims himself reformer and prophet. One thing only perhaps is steadily clear. Be he 
sensationalist or the soberest delineator of family life, the public is the first and final judge of him and his wares; and from the decision of that judge he asks no appeal.

Yet upon serious minds the magnitude of the opportunity had a sobering effect; if Thackeray grimaces occasionally, he resolutely practiced the doctrine of his introduction to Pendennis - that the truth, even though unpleasant, is best from novelist as from philosopher; and if Reade patronizes his craft, he also wrote that it was his duty to make readers aware of the evils so vividly revealed in Hard Cash and It is Never too Late to Mend. Probably never were writers more thoroughly persuaded than the great Victorian novelists of the duties of authorship. As George Eliot said, the person "who publishes writings inevitably assumes the office of teacher or influencer of the public mind. Let him protest as he will that he only seeks to amuse and has no pretension to do more than while away an hour of leisure or weariness - 'the idle singer of an empty day' - he can no more escape influencing the moral taste, and with it the action of the intelligence, than a setter of fashions in furniture or dress can fill the shops with his designs and leave the garniture of persons and houses unaffected by his industry." The divergence in practice between, let us say, Charles Reade and the framer of these words could hardly be greater; but even these extremists would have been at one in the ideal of authorship which stresses the immediate connection of letters and conduct. And so sensationalist seasoned his melodrama with preachment, perhaps of doubtful relevancy or congruity; realist added a dash of the sensational that the populace devoured with most avidity.

\section{Miscellany and Serial Fiction}

At first sight the fact that popular miscellanies and novels, the two characteristic vehicles of present-day popular 
literature, developed their vogue in the nineteenth century practically independently of each other seems odd. Yet nothing about the great magazines which made literary history, such as Blackwood's, Fraser's, and Colburn's New Monthly, is clearer than that they rested no systematic or general appeal upon instalment fiction prior to 1840 or thereabout. Previously there had been a few - a very few - sporadic examples of serial novels, notably Michael Scott's Tom Cringle's Log in Blackwood's, and one of Theodore Hook's Gilbert Gurney tales in Colburn's periodical; but these were certainly not deliberate experiments or conscious editorial departures. Blackwood or Colburn having Scott or Hook upon his hands found a serial story a practicable enough space-filler - nothing more. Now the serial idea was by no means a product of the new journalism; it is present, and near the form of serial fiction, in The Spectator, a full century earlier than the first copy of Maga. It was well enough known to the obscure magazine-makers during the last third of the eighteenth century. Smollett, indeed, had published a novel serially. Why the specific connection between the miscellany and the long story in parts, which is now a journalistic commonplace, should have waited almost a quarter of a century after Blackwood's first startled Edinburgh is not readily apparent.

The explanation even in outline is complex, but the main causes are not difficult to trace. When Blackwood's and Fraser's are spoken of as popular, it is essential to recall that "popular" is a relative term. Popular in comparison with the less frequently published quarterlies, which according to Jeffrey professed to discuss first principles of the topics they handled, these new monthly magazines with their less formal and more varied contents certainly were; in any twentieth-century sense, according to which popular means, among other things, from forty to a hundred pages of reading 
matter for a shilling or a dime, designed for the million and often reaching them, popular they were not. In any current terms Blackwood's and Fraser's at 2s. $6 d$. were costly. Nor was their circulation extensive as such matters are reckoned nowadays. Soon after the earlier magazine began its notorious career under Lockhart and Wilson, we learn from one of the Scorpion's letters to an old schoolfellow that Blackwood was printing 5000 copies, and "hoping soon to sell as many." The Edinburgh Review, which had enjoyed first innings in the new periodical market, had shortly run its circulation up to twice that figure - a phenomenal sale indeed as times went. The Review, Lockhart says, set Constable on his feet. Its prosperity grew with time, despite the Tory Quarterly 1809. Something of the tremendous expansion of magazine trade through Victorian times may be inferred from some figures of Charles Reade relative to his Wandering Heir, which was published as a holiday number of the London Graphic in 1872. Reade was then at the height of his popularity. The magazine which brought out his romance was one of the shilling group begun by The Cornhill and Macmillan's about 1860. 200,000 copies, Reade avers, were sold in Europe in that form; 150,000 more were disposed of in the United States by the Harpers, who published the story in instalments in their Weekly.

Moreover, the new ventures had no settled literary policy. The easy irresponsibility with which Blackwood and his lieutenants evaded and shifted from each to each the blame for the libels and vituperation in which they recklessly indulged is typical also of their literary program. The facility of men like Wilson, Lockhart, and Maginn in their palmy days, although the stories, like heroic tales generally, have perhaps taken on accretions, was indubitably extraordinary. Lockhart could readily produce between dark and daylight a useful article a sheet in length. In the exuberant 
and frolicsome early days of Maga, Wilson was of the opinion that a good journalist ought to turn off single-handed most of the copy needed for one issue in two days. Kenealy declares that Maginn, while a leading contributor and one of the main dependences of Fraser's, invariably wrote his entire assignment in the three or four days that preceded publication. In this facility and in the inspiration of the moment they mainly put their trust. Hence the miscellanies characteristically lived from hand to mouth; articles were projected - even announced - and never printed. Owner or editor hardly planned what was to come next.

Such policy as most of them had was provided by party politics, which were also a prime incentive in bringing them into being. When Sir Walter Scott once reproved Jeffrey for a needlessly partisan article in The Edinburgh, the editor retorted that although literature was one leg of the journal, politics was the right leg. Its inclinations being Whiggish, Murray brought out The Quarterly that Tories might have their own distinctive organ. Blackwood's was originally intended to counteract locally the Whig influence of The Edinburgh, controlled by Constable, the great publisher of the North, whose rival Blackwood aspired to be. Maginn, according to Kenealy and Shelton Mackenzie, had the same object in all the periodicals he was influential enough to dominate - whatever else he did or suffered to be done, a condition of his ascendancy was unwavering support of high Tory opinion. All this appears clearly in his foreword to the first volume of Fraser's in 1830, in which the distribution of emphasis between light literature and party politics is highly significant. "We suppose it may be taken for granted that all readers in this reading age and country so well understand what a magazine ought to contain that it would be a waste of time to say that we are to be a literary miscellany, etc." So much for mere literature; its politics 
are not so readily to be taken for granted, it appears, for Maginn requires five pages to set forth that subject. Ten years later, when Regina had completed a highly successful decade, the same writer summed up its progress in a review wherein he boasted that the miscellany had more than repaid all abusive enemies in their own coin.

The dead and gone rancors of party politics might gladly be left in their grave had they not been so violent as long to defer settled literary policy, and to deform criticism. Hazlitt upon Coleridge, Blackwood's upon Keats, Fraser's upon Bulwer are little enough edifying in all conscience; but the fact is that supporting one's opinions was understood to involve personal abuse of one's opponent without especial reference to the book he had written. Such criteria made Hazlitt call Christabel drivel and allude to Coleridge's use of drugs; they caused Blackwood's to assault Keats because he was the friend of Leigh Hunt. To the Tories at Edinburgh a distinction among odious Cockneys could matter very little. So Fraser's abused Bulwer less because he was a fop who perpetrated ambiguous Newgate romances than for the reason that he was a conspicuous liberal. Some mitigation for this there is - though not much - in the high feeling engendered by reform agitation. Virtually such writing was not anonymous, at least in the first stages of magazine-making. Maginn, brought to bay for a vicious review in 1836 , protests that at no time during the preceding twenty years to the best of his recollection had there been more than fifty regular contributors to the miscellanies. But there is little extenuation for the shuffling with fact on the part of the magazine-makers' biographers by which Wilson is held less guilty than Lockhart or Lockhart than Wilson. There is no whitewashing really possible; for too obviously one and all, whether Blackwood's staff or Fraser's, found the brutal war of personal abuse, the deliberate per- 
version of criticism, and dexterity in hairbreadth avoidance of libel most exhilarating journalistic exercise.

Traditionally, moreover, the novel was merely a book, and so it remained primarily down to 1840 . Between 1830 and 1840 the reduction of the paper tax, which had been prohibitive to cheap miscellanies, gave opportunities for ventures such as Bentley's Miscellany, of which Dickens was first editor and for which he wrote Oliver Twist, and Master Humphrey's Clock, Boz's first private periodical attempt. Master Humphrey's Clock marks pretty definitely the point at which periodicals and the novel in instalments join fortunes. It has been explained previously that The Clock was intended in part as an outlet for Dickens's stray production - occasional essays and such stories as did not fulfil conventional requirements of the novel. It was intended indeed as a kind of modern Spectator. But the audience on which cheaper periodicals depended was not the same as Blackwood's or Fraser's audience. The public, understanding Dickens's title to promise another novel, bought about 70,000 copies of his first issue; when they discovered their mistake their interest diminished. Subscriptions fell off so markedly that the proprietor had to substitute for his original intention The Old Curiosity Shop in serial form. At the same time Thackeray's Shabby Genteel Story was running in Fraser's and Samuel Warren's once famous Ten Thousand a Year in Blackwood's. From this point onward the dependence of the popular miscellany upon serial fiction was practically continuous. It is safe to say that the bulk of instalment fiction in Blackwood's, Fraser's, or The New Monthly from 1840 to 1860 singly is greater than the gross amount that they collectively had published previously.

Moreover, as indicated elsewhere, fiction was at a low ebb when the new journalism began; it was not among the approved types with which a critic who aimed at getting 
down to "first principles" - the phrase is Jeffrey's - needed to concern himself. The novel awaited Sir Walter's "big bow wow." The sensational success of Waverley, the speculations as to authorship, or the panegyrics with which the critics greeted its successors, are well known. Hazlitt, in a sentiment not so outrageous as it seems when taken in the light of current opinion, declared that John Scott, the unfortunate editor of The London Magazine, went to his death bed "with some degree of satisfaction, inasmuch as he had written the most elaborate panegyric on the Scotch novels that had yet appeared." Jeffrey could find no parallel to express his wonder save Shakespeare. "Since the time when Shakespeare wrote his thirty-eight plays in the brief space of his early manhood - besides acting in them and drinking and living idly with the other actors - and then went carelessly to the country, and lived out his days a little more idly, and apparently unconscious of having done anything extraordinary at all - there has been no such prodigy of fertility as the anonymous author before us. In the period of little more than five years he has founded a new school of invention; and established and endowed it with nearly thirty volumes of the most animated and original compositions that have enriched English literature for a century volumes that have cast sensibly into the shade all contemporary prose and even all recent poetry (except perhaps that inspired by the Genius - or the Demon - of Byron), and, by . . . variety, vivacity, magieal facility and living presentment of character, have rendered conceivable to the later age the miracles of the mighty Dramatist." 1 Scott himself wondered at the extent of the imitation his novels called out, and congratulated himself upon possession of some advantages over all competitors. Scott and Dickens were of all English novelists indeed most nearly universal; when

${ }^{1}$ Edinburgh Review, January, 1820. 
critics like Jeffrey and Hazlitt talk thus, and shilling pamphlets of a novel sell to the extent of 40,000 copies, a new era opens for prose fiction.

Directly then the three-volume story owed little before 1840 to the periodicals. Blackwood's and Colburn's New Monthly, both owned by prosperous publishers who were constantly printing books of fiction, sufficiently illustrate. The Edinburgh miscellany very early commanded the services of five writers with claims to consideration as novelists in Michael Scott, James Hogg, John Galt, Wilson, and Lockhart. Galt's Ayrshire Legatee was printed in four instalments during 1820; and Michael Scott's Tom Cringle's Log ran intermittently for several seasons about a decade later. In 1818, the second year of the magazine, Blackwood published Susan Ferrier's Marriage. Naturally too the publisher brought out the novels of his editors - The Trials of Margaret Lyndsay, Valerius, and Adam Blair. These, like Marriage, were reviewed in Maga; but Noctes Ambrosianae, however their attractiveness has faded, were better periodical material in the twenties than Galt's novels or Lockhart's.

Colburn's magazine is much more significant of the delay, inasmuch as that publisher early achieved notoriety as a rather indiscriminate trader in fiction. In 1830, after the poet Campbell had conducted The New Monthly for some years as an unpartisan journal, he was succeeded by BulwerLytton. Bulwer at that date was a flamboyant young lion in letters and a rising liberal. As a novelist he had already popularized the fashionable story in Pelham several years earlier. His selection to the post was a picturesque bid for popularity more than anything else, like Bentley's choice of Dickens; for to the public Lockhart, Wilson, and Maginn, the chiefs of the great monthlies, were hardly picturesque figures at all. Colburn already stood in the relation of pub- 
lisher of his novels to his editor, as Blackwood did to Wilson and Lockhart; but Paul Clifford and Eugene Aram came out exclusively as three-volume novels. The New Monthly had its serial articles, like its rival. During Campbell's régime it contained his Lectures on Poetry; in 1830 and 1831 it contained a series devoted to Living Literary Characters, comprising sketches of Walter Scott and Colburn's own favorites, like John Poole and Bulwer; in 1831, Sketches of the English Bar, which opened with a study of Brougham; and in 1832 and 1833, Lady Blessington's Journal of Conversations with Lord Byron. Serial fiction began in this miscellany not under Bulwer-Lytton's editorship, but under that of his successor, Theodore Hook. The volumes devoted by that notorious man of letters to Gilbert Gurney, beginning in 1835, continued more or less regularly as instalments during Hook's incumbency.

The principal use which Colburn made of his magazine in the interest of his rapidly growing novel-traffic was quite other. It was a very serviceable means of advertising the batches of novels that came from his press. One can hardly believe that the Bulwer who is reviewed so flatteringly here is the same writer whom Fraser's and The Quarterly so savagely abuse. "Perhaps never were characters more subtly analyzed," says The New Monthly reviewer of Disowned. A blanket notice of Colburn novels begins - "We are bound in duty to devote a few pages this month to the subject which heads our article; first because five of our most popular writers have selected this gloomy December as a fit and proper time to gladden and enlighten the public; and next because all the said five happen to have been among the most regular and best approved contributors to The New Monthly Magazine - Mr. Bulwer, Mr. Hook, Mr. James, Mrs. Hall, and Mr. Grattan." Colburn's log-rolling had in fact become notorious in the trade by 1830 . In $A$ 
Letter to Edward Bulwer-Lytton by Thackeray in Fraser's for December, 1831, Colburn and Bentley are especially reprehended for their novels and for their unscrupulous methods of advertising them. How much must be allowed in Regina's onslaughts for trade rivalry between competing miscellanies, for envy of Bulwer's success and genuine distrust of his early romantic vein, and for political differences, it is quite impossible to determine.

The charge against the publisher existed, however, quite independently of his connection with Bulwer-Lytton. In August, 1831, Fraser's reviewed ten or twelve "novels of the season," including apparently two egregious specimens of Pelhamism from Colburn's shop. Underneath the usual dirty rubbish of vituperation and abuse, two distinct charges to which Regina returns again and again are preferred against Colburn and Bentley; that of systematically employing the periodicals in which they are interested to puff novels printed by the firm; and secondly that of trading upon Colburn's reputation as an eligible publisher in the interests of mediocre and nasty novels. The periodicals referred to are The New Monthly, of which Colburn was proprietor, The Court Journal, which he and Bentley jointly controlled, and The Literary Gazette, in which Colburn had a third share. Now the last mentioned of these was favorably known as one of the earliest organs of disinterested criticism; but the citations from The Court Journal, in which for example a novel by Horace Smith is extolled as the equal of Quentin Durward, gives color to the charge. The gist of the whole matter is as follows: "That Mr. Colburn has in his time published some good books we do not deny. He commenced his career respectably, and gave the world sundry publications of a reputable nature, which established his name as an eligible publisher. Mr. Colburn, in connection with his 
partner, ${ }^{1} \mathrm{Mr}$. Bentley, is still in possession of notoriety; and we affirm, boldly and seriously, that, relying on his former fame, which had been unduly spread through paid puffs and juggling quackery, he now publishes ... . works which are not only immeasurably below the standard of even correct writing, - we mean correct literally, in point of language and style, - but that he is a culpable disseminator of novels abounding in heartless profligacy, grossness, and obscenity."

The essential fact, obviously, is that Colburn is the publisher of the new régime. Generous to his writers and personally genial, he was engaged in selling the kind of thing "the public want." How energetically he went about the business appears in one of John Blackwood's stories. Colburn, so his rival publisher says, caused a certain writer named Davidson to hale the sensational publisher into court concerning the return of one of Davidson's manuscripts. Within three days Colburn published the book. Again, hearing that Sydney Smith, who had recently suffered losses, must be in want of money, Colburn visited him to propose his writing a three-volume story. Smith, according to Blackwood again, proposed to take an "Archdeacon for a hero, and make him intrigue with the pew-opener. "Under the hassock,' he went on, 'would be a good place for depositing the love letters.' 'Oh,' says Colburn, 'we will leave all that to your well-known taste and judgment."'

It is significant that although by 1830 a publisher like the proprietor of The New Monthly had signalized himself as a vendor of fiction, he had not discovered the suitability of his favorite wares for periodical purposes earlier than his rivals. ' By 1840 he had gathered about him some serviceable

${ }^{1}$ Bentley was originally Colburn's chief printer. For two years, 1850-1852, they were partners. Annals of a Publishing House, II, $356-357$. 
and popular minor novelists, including those who fed the appetite for "fashionable novels"; such contributions as Mrs. Trollope's The Barnabys in America, Charles Chesterfield, The Youth of Genius, and The Robertses on their Travels; shorter tales by Mrs. Gore; others by John Poole and by Lady Blessington indicate the taste and the literary level of the modernized New Monthly.

The union of miscellany and novel is generally held to have exercised a considerable and a regrettable influence upon narrative style. John Timbs, in his book A Century of Anecdote from 1760 to 1860 , has stated the conventional view briefly in reference to Tom Cringle's Log, one of Blackwood's earliest serials. "That story," says Mr. Timbs, "is perhaps the earliest specimen of that vicious plan of narrativewriting which renders it indispensable that each number have its sensation incidents, so that when the work is completed it generally tires you with its thick-set catastrophes." Such was the general opinion of reviewers and journalistic critics of the last generation. Sir Walter Besant, a prolific serial writer himself, understands the matter differently. In his Autobiography he writes: "I saw in The Spectator the other day a notice of a certain recently deceased writer who, the reviewer pointed out, had most unfortunately brought out his novels in serial form, so that he was compelled to end each instalment with a sensational incident, a circumstance which spoiled his work. One would really think that a person allowed to write for The Spectator would have known better than to talk such rubbish; he or she would at least, one would think, have sufficient knowledge of the history of fiction to know that Dickens, Thackeray, Trollope, George Eliot, Charles Reade, Wilkie Collins, George Meredith, William Black, Blackmore, Hardy everybody of note among modern novelists - brought out their novels in serial form. Yet this fact has not spoiled 
their work. I have, if that affects the question, brought out nearly all my novels in serial form first, and I may safely aver that I never felt, recognized, or understood that there was the least necessity for ending an instalment with an incident. There is, however, no end to the rubbish - mostly ignorant and partly malevolent - that is written and published about novels." 1

With the issue between Sir Walter and Mr. Timbs as it affects serial fiction in miscellanies generally, we need not concern ourselves. What the special methods of serial writing were in the estimation of the Dickens group, what it consisted in, how far the conventional opinion of reviewers as represented by Mr. Timbs describes an essential characteristic of it, and what its relation was to their theory of the melodramatic novel - are questions of more immediate importance. If we are to progress, we must begin by distinguishing classes of periodicals and their manifest preferences in the type of story selected for serial use.

It has been noted earlier that the older miscellanies which sold for half a crown were not in the modern sense popular. The society to which they appealed is clearly enough indicated by their Tory politics. Late in the forties, also, when cheaper periodicals like Dickens's were flourishing, fiction was taking the domestic turn marked by Vanity Fair. The domestic being the newest and also Victorian high-brow sort of thing, the more pretentious magazines show a clear preference for that variety. Fraser's through that decade had some of Thackeray's minor tales and Kingsley's Alton Locke, which, though sensational, was sensational in a radically different sense from Lady Audley's Secret. Blackwood's at the end of those ten years was bringing out Lord Lytton's Caxton series. The Cornhill began with Trollope's Framley Parsonage; its rival Macmillan's with a story. by 1 Pp. 191-192. 
Hughes of Tom Brown fame. But the shilling magazines by no means contemned sensational tales of the better sort. In The Cornhill, for instance, may be found Armadale and Put Yourself in his Place. Other serials were Philip, The Claverings, Romola, and The Adventures of Harry Richmond. That Thackeray, Trollope, George Eliot, or Meredith in any sense felt bound by such rules for serial writing as were suggested by Timbs or The Spectator reviewer is absurd. They would reiterate Besant's position exactly.

Earlier, however, it has appeared that the cheaper magazines were the especial haunts of serials of the more stirring sort. The Quarterly in 1863 pointed out that four of the most notable sensation novels were printed first in Dickens's All the Year Round. Only one story of our trio, Dickens, Reade, and Collins, ever appeared in the magazines that originally sold for half a crown; Reade, late in life, contributed The Woman Hater to Blackwood's anonymously, apparently like Trollope and Lord Lytton, in a few instances, to ascertain the reception of an unsigned story of his. All except three of Dickens's novels were brought out first as shilling pamphlets. Four long stories of his own composition he published serially in his own journals. Of our trio of sensationalists Reade was least regular as magazine contributor. For about eight years at the beginning of his career he published no story in parts. During that period, from 1852 to 1860, he wrote Peg Woffington, Christie Johnstone, It is Never too Late to Mend, ${ }^{1}$ White Lies, and Love me little, Love me long. It is significant that all these except Love me little were first plays. His first tale in instalments was $A$ Good Fight, the first sketch for The Cloister and the Hearth. $A$ Good Fight appeared serially in Bradbury \& Evans's cheap miscellany Once a Week. Hard Cash was written for

1 Reade's drama Gold is worked over in that part of It is Never too Late to Mend which deals with Australia. 
All the Year Round for 1863; Griffith Gaunt for The Argosy, in which it ran serially in 1866; Foul Play for the proprietors of The Cornhill, who published it in weekly parts; Put Yourself in his Place for The Cornhill in 1870; A Terrible Temptation for Cassell's Magazine in 1871; The Wandering Heir for the Christmas number of The Graphic in 1872; A Woman Hater for Blackwood's in 1877. Collins's serial writing down to Dickens's death was mainly contributed to his friend's miscellanies. Household Words contained Sister Rose, After Dark, The Dead Secret; All the Year Round contained The Queen of Hearts, The Woman in White, No Name, and The Moonstone. Of Collins's other stories which were written before 1870, Armadale came out serially in The Cornhill; The New Magdalen in The Temple Bar.

- Dickens and his group are therefore pioneers in serial writing because they began early and practiced constantly for popular magazines. The term popular magazine, it must be remembered, has a definite meaning; it signifies a miscellany, perhaps a weekly, which sold for not more than a shilling. More costly magazines were not designed for the taste of the rank and file. But the influence of serial publication upon the Dickensians' narrative style is not simple because of their devotion to the stage and the methods of acted melodrama. Theoretically these influences are separate - practically they call for much the same set of expedients in narrative method. Yet, that there was in the estimation of Dickens and his group a peculiar procedure for serial story-writing is incontestable. "There must be a special design to overcome that specially trying mode of publication," he writes to Mrs. Brookfield, February 26, 1866, in explanation of refusal for All the Year Round of a tale of hers that he found mainly excellont, "and I cannot better express the difficulty and labor of it than by asking you to turn over any two weekly numbers of $A$ Tale of Two Cities, 
or Great Expectations, or Bulwer's story, or Wilkie Collins's or Reade's . . . and notice how patiently and expressly the thing has to be planned for presentation in these fragments." In a letter to Miss Watson in November, 1854, he complains of the difficulty of writing Hard Times as follows: "The compression and close condensation necessary for that disjointed form of publication gave me perpetual trouble." Subsequently he spoke of A Tale of Two Cities, the opening serial of All the Year Round, in very similar terms.

What Dickens meant by "compression and close condensation" may be learned from his experience with Mrs. Gaskell's North and South and A Dark Night's Work, which were originally published in instalments in his miscellany. In the preface to the volume form of the former story, Mrs. Gaskell has recorded that "On its first appearance in Household Words, this tale was obliged to conform to the conditions imposed by the requirements of a weekly publication, and likewise to confine itself within certain advertised limits that faith might be kept with the public. Although these conditions were made as light as they well could be, the author found it impossible to develop the story in the manner originally intended, and, more especially, was compelled to hurry on events with an improbable rapidity toward the close. In some degree to remedy this obvious defect various short passages have been inserted, and several new chapters added." The editor's side of the story is fortunately preserved in his correspondence with Wills in such a way as to make Dickens's doctrine of serial writing tolerably plain. "I am alarmed," he tells his sub-editor on August 19, 1854, "at the quantity of North and South. It is not objectionable for a beginning, but would become so in the progress of a not compactly and artfully devised story." From several of his letters at this time it appears that the printers have very faultily underestimated the bulk 
of North and South; whereupon Dickens sets Mrs. Gaskell to cutting down and threatens to change printers should the error occur again. This insistence upon brevity, "close condensation," is not all, however, nor yet perhaps the main consideration.

"When I read the beginning of this story," he writes Wills a few days later, "I felt that its means of being of service or disservice to us mainly lay in its capacity of being divided at such points of interest as it possesses" Another story by Mrs. Gaskell, A Dark Night's Work, reveals Dickens's concern with the same problem of division. "The third portion," he tells Wills, "consists of chapters 7 and 8 . . . The 4th portion begins with the printed slip numbered 27 . Turn over the slips until you come to the one numbered 32 . At the end of the first paragraph after the words, 'happened at a sadder time,' insert chapter X - which will then begin - 'Before the June roses were in full bloom.' Turn on again until you come to the slip numbered 34 , and stop that portion at the end of the first paragraph after it, after the words, 'except Dixon, could have gone straight to her grave.'

"The 5th portion will begin chapter 11, 'In a few days Miss Munroe married.' The story must be altogether in 6 portions, and I will send you the dividing of the last two to-morrow."

Neither here nor elsewhere did Dickens speak specifically of the incident as affected by the serial form. The implication of his phrase "a compactly and artfully devised story" is plain enough. He clearly demanded of the instalment fiction brevity and the capability of being divided so as to maintain interest $=$ both of which qualities were not readily met with in Victorian novels. These requirements by no means necessitate the melodramatic climax or even incident. The care about divisions fundamentally means nothing 
more than that the instalment, instead of being divided mechanicalty upon the basis of number of words, should have a certain unity of tone or of action - a congruity of its own. Whither this demand led will appear later. It is sufficient to note here that the doctrine of the first great serialist quite corresponds with Besant's declaration. Dickens's demand for compression and swiftness found illustration in A Tale of Two Cities and Great Expectations, the only novels which he contributed to All the Year Round. The form of publication partly explains why they are only from one half to two thirds the length of Our Mutual Friend and David Copperfield. As they appear serially in All the Year Round, moreover, they are notably free from "climax and curtain" endings for instalments.

Still this insistence upon close condensation and division at points of interest clearly tends to a relatively bald narrative and repeated thrilling climax - to the form of narrative which Reade exemplified, and for which Burnand and Punch caricatured him. The truth seems to be that the abuse of the startling incident as a means of closing the instalment was peculiarly a writer's device elaborated as the easiest and readiest way to meet such requirements of form as Dickens, in common with other writers of serial fiction, generally demanded. As a constant writer of instalment novels from the time of Oliver Twist's appearance in Bentley's Miscellany, he is clearly one of the chief contributors to the method; but his own theories and his practice by no means accord with the reviewer's generalization. The habit of leaving hero or heroine for a week or a month in a situation of the utmost peril was developed during the sixties by less notable serialists than Dickens.

When we turn to the serials of Reade and Collins the matter seems somewhat altered. Roughly speaking, instalment fiction for miscellanies during the fifties and sixties 
had to be adapted in tone and value of material as well as in length of unit of publication to the magazine for which it was designed. The unit for publication of a twenty-part pamphlet novel differed from that for Blackwood's or The Cornhill in length. The unit for All the Year Round differed from both. The shilling pamphlet novel required about two sheets for an instalment; The Cornhill required one or a little more; All the Year Round from 4000 to 6000 words, or rather less than half a sheet. In the longer units of The Cornhill the stories of Reade and Collins were studiously arranged in "climax and curtain" portions. Take, for example, Put Yourself in his Place in The Cornhill. Number one sets forth the position of Henry Little as an independent workman in the shops, and stresses the enmity between him and the trades unions. It comes to an end with the illiterate threat against his life signed sliper Jack. The second instalment, which carries on the same thread, concludes with the explosion of Little's forge and his sensational escape from death. The third and fourth parts vary the procedure; the story turns to the hero's love affairs. The third ends with a big typed exhortation to Little from Mr. Carden to have his life insured. The fifth concludes with the heroine's falling against the door of Little's secret forge in the old Cairnhope church, quite exhausted by exposure in a snowstorm. At the end of the sixth number, Coventry, Henry's rival and the villain of the piece, who was also lost in the snow, finally succeeds in reaching the church, where he discovers Henry and the girl in a very lover-like attitude. The eighth concludes with the union enemies of Little standing without the door of his secret forge ready to enter and take their vengeance. Out of fifteen instances where such

[ a conclusion is conceivably possible, Reade employs it ten times. In eight of the ten he manages to bring into jeopardy the life of hero or heroine; murder, gunpowder, and ex- 
posure are among the agents employed for this purpose in the first five numbers; attempted murder twice more, and a flood which washes away whole villages are among the remaining agencies.

Collins and Reade, especially the latter, had carried this scheme so far as to rely very generally upon what is known in the drama as "curtain lines." Of the early instalments - of Armadale in The Cornhill, which are devised in this climax curtain manner, the second concludes - "Read that, and for Christ's sake pity me when you know who I am!" The following one: "'The boat; the boat,' he cried in a scream of horror. The boat was adrift." In No Name as printed in All the Year Round four successive numbers conclude as follows: (1) At a low ebb of her fortunes the heroine is in her own room. In her hands she holds two phials. The second of these "held a dark liquid, and it was labeled Poison." (2) The heroine, being unable to resolve upon suicide, leaves her fate to chance. She sits by a casement which marks a line upon the ocean in the foreground. She decides to give herself half an hour. If during that time an odd number of vessels pass the line of her vision she drinks the poison; if an even number, she lives. Chance decides that she is to live, and the number ends when she falls asleep. (3) "What I have now to say to you must be heard by no living creature." (4) "He went to the table to rouse him. Was he deep in thought? He was dead!" Reade's narrative in Hard Cash, a story especially written for periodical consumption, abounds unusually in the same devices. The Agra, commanded by Captain Dodd, is bringing home $£ 14,000$, the hard cash for which the story is named, to his wife and children. He has just fought off two pirate ships when he meets a mischance. (1) "The captain of the triumphant ship fell down on his hands and knees, his head sunk over the gangway, and his blood ran fast and pattered 
in the midst of them on the deck he had so bravely defended." (2) At the end of the next number comes the attempt of an oriental servant to murder the sick captain. "The surgeon was not there; the two blacks, one with a knife and one with his bare claws were fighting and struggling, trampling all over the cabin at once, and the dying man sitting upon his cot, pale and glaring at them." (3) At the end of the next number Captain Dodd discovers that he. has lost the pocket-book containing the hard cash. (4) The Agra encounters a fearful tropical storm; "A voice in the dark cried - 'Oh God! we are dead men!'”

On the evidence of the serials in All the Year Round this constant arrangement of climax and curtain at short intervals is really representative of Reade's method only. It is one of his obsessions. Great Expectations, A Tale of Two Cities, The Woman in White, and No Name reveal no tendency unduly to rely upon this stage trick, though all lend themselves readily enough to such arrangement. It seems a pretty certain conclusion that, as contrasted with Reade, Collins and Dickens were fond of longer periods of suspense, and of more varied expedients to retain interest. They slowly built up and elaborated their climaxes with a copiousness of detail and of rhetorical dalliance that Reade rejected altogether. Dickens, for instance, at the beginning of $A$ Tale of Two Cities, projects the reader forward by repetition of blindly mysterious phrases - buried alive and recalled to life. From one of Dickens's letters it appears that Collins did not approve this procedure. He usually preferred a mystery which is an intellectual puzzle, not a pure mystification. In Dickens's story he urged that some significant clues be thrown out; but the master, on the contrary, went on through half a dozen numbers, rolling back bit by bit the terrible story of Dr. Manette without intimating at all clearly its significance or even its nature. But two or three 
examples of Reade's favorite climax and quick curtain scene appear from first to last. Dickens and Collins both might have subscribed to Besant's dictum; they did not understand an incident an obligatory close for the instalment even of a sensation story. In fact, they seem to have been of the opinion that melodramatic incidents were most effective when not crowded very closely together. The real secret of instalment writing was suspense; in this the incident is only one means - and one of the crudest - of achieving the end. The emphasis of Collins's famous formula for popular fiction is significant - "Make 'em laugh; make 'em cry; make 'em wait."

Indeed that the stories of this trio would have differed essentially in their treatment of incident - that startling climaxes would have been much less abundant - had they not been serialists at all is by no means certain. The indications of this may best be seen in Reade, whose Peg Woffington and Never too Late to Mend were not used for periodicals. The portion of the latter story dealing with the gold fields of Australia, which Reade had utilized in one of his earliest successful plays, reveals the dependence upon the same narrative expedient noted in Hard Cash or Put Yourself in his Place. No sooner have Fielding and Robinson been successful in their digging than their profits beget dangerous conspiracies among the less fortunate. The first plot against them comes to a head thus: the thief is stealing upon their tent in the darkness, pistol in hand, a knife between his teeth. "His hand is inside the tent - he finds the opening, and winds like a serpent into the tent." In the next chapter the thief is apprehended and dealt with according to camp law. Another conspiracy is set afoot by their especial enemy, Crawley, who is too much a coward to venture himself into danger. His henchmen have a wholesome fear of the rough and ready Judge Lynch also. In urging them on, Crawley 
insists that they have suffered nothing terrible heretofore. One ruffian especially, so Crawley urges, has had no mark set upon him by their enemies. "'Haven't they?' yelled the man, with a tremendous oath. 'Look here!' A glance was enough. Crawley turned wan and shuddered from head to foot." In the next Robinson and George Fielding set out from the mining camp in search of their mysterious enemy. When they learn that they are being followed, Robinson decides to turn the tables. Doubling on the trail, he gets his revolver ready and enforces silence upon his com-

- panion. At George's query what all this means, "I am hunting the hunted," hissed Robinson - with concentrated fury. And he glided down the trodden path, "his revolver cocked, his ears pricked, his eye on fire, and his teeth clenched." Omitting a chapter or two we come to the fight between the robbers and the miners. One chapter here ends with Crawley's dramatic discovery that he has a tail. Jacky the native has speared him in the fight; and the terror produced by this almost brings on the tremens. In the next the Australian scenes close with Crawley's dramatic discovery that his prey has escaped. Fielding and his gold are aboard a ship which Crawley discovers in the offing. "The steamer cast off and came wheeling back; the ship spread her white plumage, and went proudly off to sea, the blue waves breaking white under her bow. Crawley sat staring at all this in a state of mental collapse."

Now it may be granted that in Reade the accentuation of the melodramatic ending is slightly more shrill if possible and slightly more frequent in Hard Cash, Foul Play, and Put Yourself, which were written according to the novelist himself for serial production. That this accident in publishing accented their sensational devices somewhat is indubitable; but that magazine writing and periodical publication produced the devices can by no means be granted. Serial 
publication was only an accident in the sensationalism of Dickens and his ablest followers. It is significant that the portion of Never too Late which just served as an illustration of Reade's consistently sensational handling of his incident throughout his career was first utilized in his drama Gold. These sensationalists certainly studied all means to stimulate interest in their stories as serials; but their sensationalism had far deeper causes than any produced by an accidental form of publication. Behind it lay their literary creed - the unanimous belief in the three that as the play is spoken drama, so the novel should be written drama. Both the form of publishing and their literary dogma tended in the same sensational direction. Any attempt to distinguish sharply between the effects of these two can hardly fail to produce much that is mistaken and misleading.

\section{Novelist and Public}

Novels and novelists entered the nineteenth century with no very enviable reputation. Literary society in general was inclined to look askance at prose fiction, and plain folk of no pretensions to cultivation in letters regarded it as little short of diabolical. The elder Blackwood, as the story goes, once took home to his aged mother a story by Galt. The old lady found the book diverting enough until her son inadvertently mentioned that it was a novel. Thereafter nothing could persuade her to read another page. Mrs. Oliphant relates that in her early girlhood she asked at the circulating library for a copy of Bulwer's Eugene Maltravers. The librarian, an elderly and severe spinster, was astounded at the perversity of her taste and stubbornly insisted upon

- substituting an "improving book." Scott, who more than any other except Dickens was responsible for the vogue of the novel, said flatly in the preface to The Abbot that he did not consider the novelist as "standing high in the ranks of 
imaginative literature." A similar opinion accounts for the nominal anonymity of Man of Feeling Mackenzie, and has more to do than perhaps has been recognized with Scott's mystification as to the authorship of Waverley. To one of the two friends to whom he voluntarily confided the secret, he expressed doubts whether or not a man in his position could decorously acknowledge himself a writer of fiction. The reviewers of the new journalism which came into being with the Edinburgh and Quarterly Reviews reveal the same prejudice. Contemporary notices of Lady Morgan's novels and of Maturin's indicate that the reviewers expected fiction to be more or less trivial or absurd, and made blunderingly sturdy efforts to find it so regardless. Indeed they often apologized with a very annoying condescension for noticing such books at all.

For this disrepute the novelists themselves were partly responsible. Fielding, Smollett, and Sterne had left a tradition of grossness which new times and new manners made obnoxious. The new romance for which Mrs. Radcliffe won approbation hardly recovered from the opprobrium which Lewis's Monk brought upon it. Not even the propriety of Mrs. Radcliffe, which made feeling for bold scenery a criterion of character, or the solid basis of thought in St. Leon could quite redeem it. Despite Scott, romance succeeded very tolerably by one vagary and another in retaining the flavor of disrepute. Byron's influence led directly to the Newgate novel of the thirties, in which the Gothic monster is but scotched. The realism of Maria Edgeworth and Jane Austen, though well received by the few, was quite destitute of the big bow wow. Thus romance was handicapped by popular prejudice, by the pedantry of reviewers, and by the vagaries of its producers themselves. This was by no means all. The increase in the reading public combined with a reform in national manners led to almost in- 
credible smugness and prudery. Respectability in the odious sense of Victorian times became rampant. So far as fiction is concerned respectability meant that if certain topics could be kept out of consideration all would be well with its health; vice and misery were vulgar; telling the plain truth, drawing a man as he is, Thackeray said, drove subscribers away.

For all this in the criticism of the thirties and forties there is some excuse. Behind it are the fear of a rowdy and unclean press and serious concern for English institutions and society. The novelist's struggle for freedom of utterance and of theme, for acceptance as a serious commentator upon life as he saw it, was a bitter one. As Dr. Downward, in Wilkie Collins's Armadale, has it, the novelist was expected only to amuse his readers, and occasionally to make them laugh. If he chose to picture the misery of London, he was vulgar; if he delineated to his utmost a man, the tongues of good ladies in their homes and in the reviewers' offices became shrill. If he chose, like Bulwer in Paul Clifford, to expound the workings of a brutal criminal law, he had to shirk vital details of his demonstration; and if he touched upon illicit love, as Oliver Twist did, he had to drape his Nancy in a speech as foreign to her as Mrs. Malaprop's is to sense. Nothing can be more enlightening, as to the temper of Victorian criticism and public, than Ruskin's "exception with honor" of Oliver Twist "from the loathsome mass to which it belongs." "This loathsome mass" includes among others specifically Bleak House, Barnaby Rudge, The Hunchback of Notre Dame, and Wilkie Collins's Poor Miss Finch. ${ }^{1}$ No novelist, not even Scott, escaped the prudery which would have limited Victorian novels to subject matter appropriate to the best regulated Sunday school library. Modern letters

1 "Fiction Fair and Foul." The Nineteenth Century, vol. 7, pp. 948-949. 
afford few spectacles more grotesquely humorous than that of critical nonentities of now defunct journals reprehending Walter Scott and Thackeray on grounds of public morality. This prudery was by no means restricted to the well-meaning hacks who criticized novels according to the standards of religious cults or of acidulous maiden ladies. It extended up the scale to Edinburgh and Quarterly. Representatively enough, Jeffrey, in collecting his essays on literature at the end of his career, insists upon his efforts to preserve morality as his prime claim to remembrance.

The vagaries perpetrated in the interests of this morality by those who should have known better are often all but incredible. In St. Ronan's Well, according to Lockhart, good James Ballantyne objected to the mischance which explains Clara's shattered mind. Jeffrey is responsible for obscuration of the intrigue in Dombey and Son between Mrs. Dombey and Mr. Carker. Dickens intended that Edith should be the mistress; but the objection of the critic, heeded with no happy result, imposed upon the story a situation which is neither convincing nor even quite intelligible. Dr. Arnold preached a sermon against the monthly numbers of Nicholas Nickleby. Trollope relates that a certain McLeod, the editor of Good Words, was much perturbed because Rachel Ray, which the novelist was contributing as a serial to that journal, dealt approvingly with dancing.

There is nothing odd really then in the fact that Thackeray, who had done fiction excellent service as a contributor to Fraser's in driving the Newgate romance out of fashion, should have been long spitefully attacked for want of religion and morality. Among women at least it was only the exceptional reader, like Charlotte Brontë or Mrs. Cárlyle, who openly and unequivocally admired Vanity Fair and Pendennis. Harriet Martineau thought that "the first 
drawback in his books, as in his manners, is the impression that he never can have known a good and a sensible woman." Mrs. Jameson delivers a diatribe on Lady Castlewood thus: "The virtuous woman par excellence who never sins and never forgives; who never resents, nor relents, nor repents; the mother who is the rival of her daughter; the mother who is the confidante of a man's delirious passion for her own child, and then consoles him by marrying him herself." How Thackeray chafed under such prudery and rule of thumb morality the preface to Pendennis testifies; and no matter how familiar it may be, no truer indictment of the halfcultivated bourgeois audience that paid for and restrained fiction two generations ago was ever written. "Since the author of Tom Jones was buried no writer of fiction among us has been permitted to depict to his utmost power a man. We must drape him and give him a conventional simper. Society will not tolerate the natural in our art. Many ladies have remonstrated and subscribers left me because in the course of the story, I described a young man resisting and affected by temptation. My object was to say he had passions to feel and the manliness and generosity to overcome them. You will not hear - it is best not to know it - what moves in the real world; what passes in society; in the clubs, colleges, mess-rooms--what is the life and talk of your sons. A little more frankness than is customary has been attempted in this story, with no bad desire on the writer's part, and with no ill consequence to the reader. If the truth is not always pleasant, at any rate the truth is best from whatever chair - from those whence grave writers and thinkers argue, as from those at which the story-teller sits as he concludes his labors and bids his kind readers farewell."

Thackeray knew well enough the recipe for success, if his regard for truth had permitted him to use it. "You 
would have the heroine of your novel so beautiful that she would charm the hero with her appearance; surprise and confound the bishop with her learning; outride the squire and get the brush; and when he fell, whip out a lancet and bleed him; rescue from fever and death the poor cottagers the physician had given up; make twenty-one at the butts when the poor captain scored only eighteen; give him twenty at fifty in billiards and beat him; and draw tears from the professional Italian people by her exquisite performance (of voice or violincello) in the evening - I say that if the novelist would be popular with the ladies - the great novel readers of the world - this is the sort of heroine who would carry him through half a dozen editions." Hampered thus by a public which shrank from frank presentation of the truth, yet found keen delight in Rookwood and Eugene Aram during the thirties, or in Lady Audley and Strathmore during the sixties, it is not strange that Thackeray waited long to be heard, or that there is much bitterness in Codlingsby or George de Barnwell.

Yet essentially underneath this superficial manifestation of taste which results from the enfranchisement of the many, it was a period of growing liberalism. The decade preceding Oliver Twist had been marked by Catholic emancipation, the first Reform Bill, and the achievement of good cheap reading matter by the Society for the Diffusion of Useful Knowledge. When the Reform Bill of 1832 gave redress to the middle classes, however, it still left the plight of the laborers desperate. Poor laws that encouraged pauperdom, protection of agriculture which artificially maintained the high price of corn, intolerably long working hours in mines and factories, and squalid, overcrowded living quarters in the manufacturing cities called for immediate and drastic action. With reformatory zeal which characterized men of heart, a group of young novelists seized 
upon fiction as a means of influencing reform; and from 1844 or 1845 onward for ten years produced a body of fiction which seems to have contributed to a bolder and more downright method of narrative. Bulwer had set the precedent with Paul Clifford in 1830. Disraeli in Coningsby, Sybil, and Tancred set forth his conception of Young England; Kingsley in Yeast and Alton Locke hastily flung into story form first-hand studies of conditions in agriculture and in the London sweat shops. Mrs. Gaskell in Mary Barton and North and South and Dickens in Hard Times contributed realistic reformatory tales of the manufacturing cities.

The peculiar contribution of the utilitarian romance was in method. As has been illustrated in Ruskin's comment upon Dickens, a professed moral purpose went far in these days; in these reformatory stories, for instance, it justified calling a spade by its right name. At the same time that Thackeray was urging of Becky, Jos. and Lord Steyne "such people there are, dear reader - let us have them with might and main," Disraeli in Sybil and Kingsley in Yeast and Alton Locke were employing a deliberately naked and gruesome truth of incident, detail, and character to shock the public into active interest for the workers. The passages of Alton Locke that remain longest in the memory are the excursion of Sandy, the old Scotch bookseller, with the hero through the garrets of London in search for vital subjects for Alton's muse, and the death of Jeemie Downs, the wretched tailor. But the startling literalness of these scenes did not exist for its own sake, nor were the novelists even so quite at ease as to its reception. Kingsley is openly apologetic for it, pleading his purpose as excuse; and Disraeli in Sybil declares that he did not make the terrible sketch of the weaver Warner's family as terrible as the reality. It was, therefore, only a question of time when novelists should enforce their right to employ this literal truth-speaking 
at discretion. No Victorians were more insistent for a liberal construction of their art than the Dickens group. As Dickens and Collins once put it, they were "serious minds with serious objects," esteeming themselves not only entertainers but leaders and makers of popular opinion. Their sensationalism was seriously applied to questions of widespread interest in contemporary life - to cheap schools in Nicholas Nickleby, to laws relating to marriage in No Name, to labor unions in Put Yourself in his Place. Their belief in "publicity" was unbounded, and they accordingly not only made an avowedly popular appeal, but prided themselves upon doing so.

This attitude is apparent in all that they did. Dickens entered upon periodical-making to gain profits that under the older system found their way to the publisher's pockets, but remained to conduct two model cheap papers. When he printed the words "Conducted by Charles Dickens" at the top of his sheet, he understood himself to be pledging a personal reputation upon the quality of Household Words or All the Year Round. How badly merit such as he could command was needed in the cheap press that had sprung up before mid-century, and how middle-class society felt about that press may be gathered from a study of Thackeray's in Fraser's for March, 1838. This article, bearing the title Half a Crown's Worth of Cheap Knowledge, is a description of fifteen current cheap journals, and a criticjsm by implication at least of The Society for the Diffusion of Useful Knowledge. Thackeray brought The Poor Man's Friend, Liversay's Moral Reformer, The Wars of Europe, The Penny Storyteller, The Sporting Gazette, The Sporting World, Oliver Twiss by Boz, The Weekly Magazine, The Fly, The Penny Age, The Penny Satirist, Cleave's Penny Gazette, The London Satirist, The Star of Venus or The Show-up Chronicle, and The Town. His comment upon this nondescript assemblage 
is not more lugubrious than that of most other conservatives. "The school master is abroad and the prejudices of the people disappear. Where we had one scoundrel we may count them now by the hundred of thousands. We have our penny libraries for debauchery as for other useful knowledge, and colleges, like palaces, for study - gin palaces where each starving Sardanapalus may revel until he die." These were not mere empty expressions that Dickens wrote in foreword to Household Words: "There are some already in the field before us, panders to the basest passions of the lowest natures, whose existence is a national reproach, and these we should consider it our highest service to displace." The same seriousness appears in a letter ${ }^{1}$ by Reade to one of the correspondents stirred up by $I t$ is Never too Late to Mend, the novel in which Reade applied the sensational method to prison regimen. "Those black facts (inhuman governors and fatally brutal methods of discipline) have been before the public before I ever handled them; they have been told, and tolerably well told, by many chroniclers. But it is my business, my art, and my duty to make you ladies and gentlemen REALIzE things which the chronicler presents to you in his dim, stolid, and shadowy way; and so they pass over your mind like idle wind." Or again he retorted with characteristic vehemence to a critic of his handling of trade unions in Put Yourself in his Place that he was, in his small way, a public benefactor. Whoever calls the author of that story a criminal "is a liar and a scoundrel."

The Dickens group were not, therefore, altogether in sympathy with the current methods of "improving the masses." Mutual improvèment societies, lectures, informational reading matter which quite ignored appeals to fancy seemed to them very unlikely to achieve the purpose. The masses themselves never resented more hotly the solemn

1 Memoir of Charles Reade, p. 244. 
seriousness and the patronage in most of these attempts. Dickens defines his notions of serviceability in light literature in the first number of Household Words. "To show all, that in all familiar things, even in those which are repellent on the surface, there is Romance enough, if we will but find it out - to teach the hardest workers at this whirling wheel of toil that their lot is not necessarily a moody, brutal fact excluded from the sympathies and graces of imagination; to bring the greater and lesser, in a degree, together upon that wide field and mutually dispose them to a better acquaintance and a kindlier understanding - is one main object of our Household Words." 1 Again, Dickens, reproached by Charles Knight for throwing his powerful influence upon the side of fiction rather than that of useful knowledge, retorted: "The English are, so far as I know, the hardest worked people on whom the sun shines. Be content if in their wretched intervals of leisure they read for amusement and do no worse. They are born at the oar, they live and die at it, Good God, what would we have of them!" 2

In similar vein Reade declared novels to be "the only cheap yet ravishing delight the world affords." Collins also deprecated the solemnity and heaviness of current methods of enlightening the public. In Chapter 6 of $A$ Rogue's Life he breaks out characteristically: "My unhappy countrymen! (and thrice unhappy they of the poorer sort) - any man can preach to them, lecture them, and form them into classes; but where is the man who can get them to amuse themselves? Anybody may cram their poor heads; but who will lighten their grave faces? Don't read story books, don't go to plays, don't dance! Finish your long day's work and then intoxicate your minds with solid history,

1 Foreword to first issue, March 30, 1850.

${ }^{2}$ Passages of a Working Life. Knight's reissue, vol. 3, pp. 16, 17. 
revel in the too attractive luxury of the lecture room, sink under the soft temptation of classes for mutual instruction. How many potent, grave, and reverend tongues discourse to the popular ear in these siren times, and how resignedly this same popular ear listens. What if a bold man spring up one day crying aloud in this wilderness: Play, for Heaven's sake, or you will work yourself into a nation of automatons. Shake a loose leg to a lively fiddle. Women of England! drag the lecturer off the rostrum, the male mutual instructor out of his class, and ease their poor addled heads of evenings by making them dance and sing with you. Accept no offer from any man who cannot be proved for a year past to have lost his dignity at least three times a week after office hours. You, daughters of Eve, who have that wholesome love of pleasure which is one of the greatest adornments of the female character, set up a society for the promotion of universal amusement, and save the British nation from the lamentable social consequences of our own gravity. Imagine a voice crying lustily after this fashion. What sort of echoes would he find? Groans."

Obviously men who talk thus about romance and amusement consider themselves something more than idle singers of an empty day. Romance is a serious business; inevitably their sensationalism thus seriously applied brought them into frequent conflict with critics and conservative public. Thackeray listed Oliver Twist among the Newgate novels of Bulwer and Ainsworth; Ruskin cited Barnaby Rudge, Bleak House, and Nicholas Nickleby as foul fiction. Trollope, quite representatively of a large part of the public, thought that Reade's reformatory novels exaggerated and falsified the objects of attack. Two continents bawled carrion at Griffith Gaunt and A Terrible Temptation; The Quarterly slated No Name, the first onslaught by Collins on marriage laws, as belonging to the same category with The 
Last Days of a Bachelor and Pages from the Life of a Fast Young Lady; The Athenaeum in 1866 noticed Armadale and Ouida's Chandos in a blanket review without finding essential difference between them in purpose or merit. That the novelists retorted upon such criticism acrimoniously is only human nature. The replies themselves will serve to define more clearly the general attitude of the Dickensians toward the art and purpose of fiction-making and toward the public.

The first of these onslaughts was a joint essay by Dickens and Collins entitled Dr. Dulcamara M.P. which was printed as a leading article in Household Words, December 18, 1858. The Right' Honorable Sidney Herbert on the Hustings had ventured into criticism of fiction with a eulogy of domestic novels which he extolled at the expense of the dramatic and tragic varieties. He had quoted Guizot in comparing English and French novels as follows: "In science we match you; in poetry we match you . . .; in history we match you; but we have not got anything in our literature like The Heir of Redclyffe and your domestic novels. All books of that class are peculiarly English. They are books describing a virtuous domestic life - books describing a simple domestic life. They do not go to the tragic or dramatic for interest, but they draw it from the simple springs of natural life. This we have not got in the literature of France." This implied derogation of the sensational and the tragic stirred a contemptuous wrath in the office of Household Words. Protesting that their "previous want of acquaintance with this Pusey-novel arose from no barbarous indifference to the important literary events of our age and country," but from fear of reading so affecting a story as they have observed Miss Yonge's to be, Dickens and Collins proceed to ridicule The Heir of Redclyffe on the grounds that its characters "have no types in nature; 
never did have types in nature; and never will have types in nature." They poke very heavy-handed fun at the hero's flaring up at a light remark about King Charles I, which "rouses the lion in him" and sets "his hazel eye gleaming like an eagle's." They revolt from the subjection of the art of narrative to the ideals of a particular religious cult. No, they conclude, "France will have no such book as this until she has the two classes which such a book addresses. The first class, a large and wealthy section of the so-called religious world, which looks to the obtrusively professed intention of a book solely, and knows and cares nothing about the execution; the second class represented by a body of romantic young ladies whose ideal man (name and all) is exactly represented by such a character as Sir Guy Morville." Let the Sidney Herberts and the Guizots go about addressing athenaeums, and "let the Athenaeums take their physic, if they like it and feel better for it; but let them be held at a distance by earnest men with definite objects before earnest minds, and those objects tending not to the retrogression of their country into the dark ages, but to its advancement in the plain road that opened eighteen hundred and fifty-eight years ago."

The limitations which "respectable" folk would impose upon the art of fiction is treated with a defter touch in A Petition to Novel Readers by Collins alone. ${ }^{1}$ The satire is based on the Spectator expedient of a letter to the editor purporting to be written by a romantic gentleman who resides in the country where he reads fiction inveterately. The romantic gentleman has just disrupted the provincial literary society to which he had belonged by the introduction of a novel in place of the customary books of travel and of improving knowledge. The novel had almost produced a riot; one member objected that the author was a pantheist;

${ }^{1}$ Reprinted in My Miscellanies. 
and though nobody seemed to know what a pantheist is, the members cried hear! hear! "which did just as well for the purpose." Another gentleman said the book was painful because there was a death bed scene in it. The knell of fiction, however, was rung by the mother of "a large family, whose oldest was a girl of eighteen and whose youngest a boy of eight months, who objected that in the course of the three volumes, the heroine had two accouchements. . . . "'How can I suffer my daughter to read such a book as that?' cried our prolific subscriber indignantly. A tumult of applause followed. A chorus of speeches succeeded, full of fierce reference to our national morality, and the purity of our hearths and homes." Finally a resolution was passed that novels be excluded from the club. The romantic gentleman, for his part, has decided to take an unlimited subscription to a London circulating library and have down a box of novels every month. But he and his family have quite lost caste in their community. "If the dull people of our district were told to-morrow that my wife and daughters had all eloped in different directions, leaving just one point of the compass open as an outlet for me and the cook, I feel firmly persuaded that not one of them would be inclined to discredit the report. 'This is what comes of novel-reading,' they would say, and would return, with renewed zest, to their voyages and travels, their accouchements in real life, their canting national morality, and their blustering purity of our hearths and homes."

Reade's Griffith Gaunt in 1866, and A Terrible Temptation, six years later, involved him in a quarrel as to the novelist's scope with the public of two continents. The first of these stories was built upon the typical "sensation" motives, bigamy and murder; the second, upon a family feud and the desire of a reformed rake for a son and heir. In the early chapters of $A$ Terrible Temptation there is an amusing enough 
sketch of the wiles of Rhoda Somerset, then the kept mistress of one of the leading characters. The sketch was, scornful and masculinely humorous enough, one would think, to have escaped the strictures of Mrs. Grundy, but The Times, nevertheless, complained that the tale dealt with things the novelist had no business to present, and even hinted that wise mothers would do well to keep "the first volume from their unmarried daughters." Reade retorted that The Times itself had given him the idea for Rhoda. The Times representatives unwisely tried to escape this awkward rejoinder by the argument that theirs were public duties, whereas Mr. Reade's were private. "Why," roars Reade, "my English circulation is larger than that of The Times; and in the United States three publishers have sold 370,000 copies of this novel - which, I take it, is about thirty times the circulation of The Times in the United States, and nearly six times its English circulation." As the novelist sees it - "Journals must of necessity report in their small type some crimes and vices quite unfit to be mentioned in a novel; but that a journalist has any right to put in his leaded type and to amplify and discuss, and dwell upon any subject whatever, and that the poet and the novelist has not an equal right to deal with that subject in fiction this is monstrous and the mere delusion of rabid egotism."

"Since, therefore, I have taken anonyma from your hands and have presented her in no voluptuous scenes, and have made her a repulsive character until she repents, no mother need forbid my book to her daughter; at all events until she has forbidden her daughter to enter Hyde Park, and The Times to enter her drawing room, and has locked up every Bible on her premises."

As courageously as Thackeray they too believed that the truth is best; and for "the clap trap morality of the present," as Collins describes it in the preface to Armadale, they had 
the bitterest contempt. This contempt grows out of the seriousness with which they took themselves and their art. It is significant that in the letters exchanged between them are many references to "the art," "our art,". and that they describe themselves over and over as brothers in it. But their truth was not the humdrum truth of everyday experience. Based, as we shall see, upon attested fact, it deliberately chose for representation the unfamiliar and sensational manifestation. Whether this highly serious sensationalism in its characteristic application to local and temporary conditions - to divorce laws, prison reform, and the Court of Chancery - was beneficial to their fame subsequently may be doubted. Not to students and critics only, but to readers generally the burden of specific purpose appears to have spoiled the flavor of brilliant work. One and all are best remembered now for tales that had no thesis - Dickens for David Copperfield and Great Expectations, Reade for Peg Woffington, Christie Johnstone, and The Cloister and the Hearth, Collins for The Woman in White and The Moonstone. Such at least is the almost invariable testimony of the libraries of cheap reprints. Still the resolute fight for a liberal construction of their art in a prudish society, growing out of an earnest devotion to it and an effort to make it more than others made theirs a powerful and immediate influence upon the life of the time, contrasts favorably with the frank commercialism of Trollope or the frequent dubiety of Thackeray toward his chosen profession. Theirs is not the confidence of conceit, but that of men who see a work to be done and feel a certainty of their ability and election to perform it.

\section{Summary}

In about thirty-five years from the date of Constable's ll-fated Miscellany, the old order had ended and the new 
was established. Pamphlet novel, cheap miscellany, and circulating library had forced down the price of fiction, though the reactionary custom of publishing in three volumes operated to preserve an unconscionable length. When at last paper taxes were reduced, cheap journals became increasingly numerous. These cheap journals, upon which the taste of the time forced the serial novel, particularly affected the sensational serial, and gave it a new and distinctive narrative method. From this trade turmoil and change the novelist emerged the great literary wage earner. He found himself no longer a sort of pariah of letters, but the favorite entertainer and teacher. Under these circumstances he demands the right to become a serious critic of life. His newborn dignities, however, he bears a little uneasily; but knowing the public, not the bookseller, to be the arbiter of his fate, to the public directly he appeals.

Such is the background for the work of the Dickensians as exploiters of fiction. In a sense, of course, it is the background for the Victorian novel generally - for Thackeray, Trollope, and George Eliot as well as for Dickens, - Collins, and Reade; but not by any means in the same degree. The domestic was high-brow fiction; the sensational of the Dickensians avowedly popular. With one exception no serial written by one of them appeared in a magazine which sold for more than a shilling. There is not, moreover, one of these notable changes affecting novels - lower prices, promotion of cheap magazines, increased wage for novelist, the struggle of the story-teller for acceptance as a serious commentator upon life - in which Dickens did not engage; none in which he did not exert an influence as powerful as that of any man of letters of his time.

Not since the Puritans closed the theaters had public and men of letters been so intimate. Indeed the great epoch of the drama and the great epoch of the novel are 
roughly analogous. Under similar conditions of direct appeal of writer to audience there arise similar products; for just as direct appeal in the Elizabethan theater called out the tragedy of blood which Hamlet or The White Devil glorified, so here among the Victorians it gave vogue to the sensationalism which Great Expectations and The Moonstone rendered memorable. The heel of the buskin has been perceptibly lowered; but one can no more fail to recognize that sensationalism represents a halfway station between the tragedy of blood and the moving picture, than that both grow out of the direct communication of storyteller and story buyer. Above all, both are democratic art. Trade phenomena alone, of course, do not explain completely the sensationalism of the Dickens group. Beyond local and temporary conditions of trade and of public are further matters of temperament and of literary tradition - of innate love for the theatrical whether behind the footlights or between the covers of a novel. But trade conditions are clearly an essential reason why they are in one breath makers of incredible melodrama and officious moralists. It was their interest in and conformance to these new conditions, both as men of business and as men of letters, that constitute their especial title to recognition as the democrats of the Victorian novel. 


\section{CHAPTER III}

\section{THE SCHOOI, OF DICKENS}

7. The Literary Fraternalism of Dickens, Reade, and Collins

Although the personal and professional relations between Dickens, Reade, and Collins were by no means uniformly intimate, these novelists may nevertheless be said to have formed a school in much fuller sense than is usual among English writers. At the beginning of Collins's career as a professional writer in the early fifties, he and Dickens were already more than fellow workmen with common aims, and more they remained until the elder's death. From a little after 1860, also, Collins was numbered among Reade's small circle of intimates. Between Reade and Dickens, however, the bond was of necessity mainly a fraternalism in art arising from devotion to common ideals. To the expressed regret of both, personal association was rare, inasmuch as practical interests drew them apart. Yet there is sufficient evidence both for their substantial unanimity of creed as story-tellers and for their mutually affectionate admiration. Reade spoke of Dickens in terms of praise that he applied to no other contemporary; and Dickens, in turn, addressed Reade as a brother in the art at a time when hostile criticism was unusually busy with Griffith Gaunt. It is worth while noticing, too, that Reade was among those who were remembered after Boz's death with mementos from the great novelist's study.

Dickens indeed was probably highly influential in Collins's definitive choice of letters for a profession; for before jour- 
nalism associated them in Household Words and All the Year Round, Dickens had constituted himself a kind of mentor to the younger man. "I may assure you," he wrote to Collins, December 20, 1852, concerning Basil, "that I have read the book with very great interest, and with a very thorough conviction that you have a call to this same art of fiction." 1 To a young man anxiously awaiting the reception of almost a first venture in letters, this praise from the greatest popular favorite of the generation must have seemed encouraging indeed. At all events, Basil was a turning point in Wilkie's career; and by September, 1856, he had proved himself sufficiently valuable for the editor of Household Words to desire his retention upon the staff. In September of that year Dickens wrote to his sub-editor Wills: "I have been thinking a good deal about Collins, and it strikes me the best thing we can do just now for Household Words is to add him on to Morley, and offer him five guineas a week. He is very suggestive, and exceedingly quick to take my notions. Being industrious and reliable besides, I don't think we should be at an additional expense of $£ 20$ in the year by the transaction. . . . I think it (the connection) would do him, in the long run, a world of good, and I am certain that by meeting togetherdining three instead of two, and sometimes calling in Morley to boot - we should knock out much new fire." 2

At the time of this letter their acquaintance was already of several years' standing. They had met in 1851 apparently; prophetically enough their personal intimacy grew out of common interest in the theater and things theatrical. In September of the ensuing year Collins assisted in performances organized by Dickens for Tavistock House, the time from which personal friendship dates. In 1853 Wilkie wrote The Lighthouse to be performed in
${ }^{1}$ Letters, I, p. 294.
${ }^{2}$ Charles Dickens as Editor, p. 221. 
the same place, and the same year came his first serials for Household Words, Sister Rose, After Dark, and The Dead Secret. From that point onward Dickens was well enough assured of Collins's capabilities to admit him as a collaborator. Together in 1857 they wrote The Lazy Tour of Two Idle Apprentices, of which Dickens boasted that one could hardly tell where he left off and Collins began. In 1858 they wrote jointly the article entitled Dr. Dulcamara, M.P. for Household Words, a critical essay of considerable importance in revealing their prepossessions in the art of fiction.

Meanwhile, Collins was making good his claims to favorable opinions in other ways. His Queen of Hearts appeared in All the Year Round in 1859; The Woman in White, his first great hit, which brought him esteem comparable with that of the foremost novelists, appeared serially in the same periodical the following year. After 1860 he was no longer the able but obscure henchman of the chief, for in that tale he had found a manner of narrative which he knew how to make peculiarly his own. The Woman in White, indeed, fastened upon him a reputation for plot construction which later in life he vainly tried to extend and enlarge by means of such purpose-stories as Man and Wife, The Law and the Lady, and Heart and Science. The vogue of The Woman in White shortly opened the columns of The Cornhill, the new shilling venture edited by Thackeray, to Armadale. Collins still remained a trusty in All the Year Round, upon whose judgment the editor strongly relied. He still collaborated with Dickens in Christmas numbers of the journal, and during the chief's second visit to America, took over some of the editor's duties.

Between Reade and Dickens there never existed the same degree either of personal or of professional intimacy as between Dickens and Collins. Although the elder novelist was probably the one contemporary the assertion 
of whose superiority to himself would not have provoked a characteristic fulmination from Reade, the author of Hard Cash was little more professionally than a contributor whose one story for All the Year Round wrought unexpected havoc in the editorial sanctum and in the circulation. Reade, however, differed from Collins in that he had acquired a national reputation by It is Never too Late to Mend six or seven years before he published Hard Cash in Dickens's miscellany. From the first, however, he had felt the spell of Boz and had paid him the sincerest sort of flattery in Christie Johnstone. Singularly self-reliant and independent workman though Reade was, he went about London in disguise early in his apprenticeship to fiction, fancying that he could find incident and persons to capitalize as the master had done. This procedure, however, was not productive of more Swivelers, but of the realistic study of the Scotch fisher folk in Reade's second novel. Christie Johnstone, in this sense, is probably more consciously imitative than any other story of his.

Dickens and Reade first met through the kind offices of a fellow novelist whom they both greatly admired - BulwerLytton. In November, 1859, Reade, already interested in International Copyright, visited Dickens armed with a letter of introduction which ran thus: "My dear Dickens, - Herewith let me present to you Mr. Charles Reade, whose works and pen are too well known to you to need lengthened introduction. He would like to talk to you on a favorite subject of his for improving the interests of authors. Yours ever, E. B.-Lytton." Whatever influence the meeting may or may not have had upon International Copyright, it was nevertheless the beginning of a friendship and mutual interest that lasted until Dickens's death. The younger man's admiration for the dramatic quality of Dickens, as has been indicated, was outspoken, and far 
exceeded that which he yielded to any other contemporary. The nature of this homage, and one especial quality upon which it rested, appear in Reade's curious study The Eighth Commandment, 1860, in which his interest in copyright, particularly as it relates to stage pieces, bore fruit. "Mr. Dickens," Reade asserts in chapter eight, "is a great actor and a great dramatic novelist - i.e., a novelist out of whose early novels good plays have been cut by scribblers destitute of dramatic invention." 1 Again in the same book he wrote: "Mr. Dickens is the most extraordinary artist in one respect England ever produced. He is a first-rate writer of fiction, and a first-rate actor. England has had just five men of this sort in three hundred years - Shakespeare, Cibber, Macklin, Garrick and Dickens." That the admiration was mutual is apparent from the circumstances under which Dickens's comments on Reade were penned. There is good reason to suppose that Dickens wanted Reade upon the staff of All the Year Round as early as 1860; but the younger novelist, with three successful stories to his credit before that time, could hardly find such a relation profitable. In whatever capacity Reade's services may have been desired - whether as Mr. Lehmann ${ }^{2}$ supposes in some such connection as Collins's became, or merely as a contributor of projected sensational successors to It is Never too Late to Mend, we find Dickens writing to Wills, his subeditor, under the date of September 26, 1860: "I have both heard Reade and seen him. There is only one obstacle, and that is a treaty he has with Ticknor \& Fields. It is possible the obstacle may be overcome. We must have a talk about it. I have engaged him to dine here on Saturday in next week at six. . . . I write by this post to Wilkie in order that notice of the feast may reach him on

1 The Eighth Commandment, p. 154.

${ }^{2}$ Charles Dickens as Editor, N. Y. 1912, p. 281 (note). 
his coming to town." 1 It was somewhat over a year apparently before anything came of the scheme to secure Reade's coöperation.

In January, 1862, there is another letter between Dickens and Wills concerning contributions from Reade to the journal. "He seems to me the best man to be got for our purpose," ${ }^{2}$ the editor writes. "But I think his terms will be higher than yours. I think you might at once go up to five and twenty pounds a week. But he may not be used to such receipts as I suppose. I would certainly pursue the idea with the intention of getting him as the best man to be got. No doubt he would be glad to work with me. I believe he has a respect for me." There was a slight hitch over terms. His employers desired the American rights to the story, which Reade estimated at about $£ 300$. Reade felt confident that All the Year Round must come to his terms. . "Dickens,". he wrote to Mrs. Seymour, "is working on a shilling serial and Collins going to The Cornhill. So I shall stand firm about the American streets, and, please God, shall publish the new story hot (i.e. writing each number up to time, instead of completing the whole before commencement) for All the Year Round. A clause gives me the right to bring it out three weeks before the termination in the periodical, and when we shall have made $£ 5000$ by publication we will combine a little dramatic spec." Wills seems to have conducted negotiations to the satisfaction of all concerned, for on the eighth of the month Dickens adds, apparently in reply to Wills's communication of Reade's acceptance: "Reade, good. I would give him what he asks, holding him to a certain space within which the story shall be comprised." 4

${ }_{1}$ Charles Dickens as Editor, N. Y. 1912, p 281.

2 Ibid., pp. 303-304. $\quad{ }^{3}$ Memoir of Charles Reade, p. 306.

4 Charles Dickens as Editor, p. 305. 
The story by which All the Year Round was to be so benefited finally appeared as Hard Cash, a title to which Dickens suggested the alternative Safe as the Bank. But the serial from which both writer and publisher obviously expected great things, oddly proved a great disappointment in its periodical form; and the chief results of Reade's only publication under the auspices of his master were the reduction of the circulation of the magazine by three thousand copies and a very narrowly averted quarrel with its editor and proprietor. Though no novel combines in more even balance all the elements that made Reade popular - the vivid dramatic method, the unflagging variety of incident and scene, the sincere reformatory purpose, and characters, like the Dodd family and Dr. Sampson, yamong the best he ever drew - the seriat by no means pleased readers of All the Year Round. ${ }^{1}$ Moreover, ${ }_{\text {Dickens made no secret }}$ of his disapproval of views that Reade expressed in the story

. The trouble arose because the novelist with customary vigor fell upon The Lunacy Commission, of which John Forster was a member. Reade tried his best to exonerate Forster; but the editor took two occasions to remark in print that he did not share his contributor's opinions. The instalment of Hard Cash for November 14, 1863, has a few lines in description of an energetic commissioner that are meant to appease Forster and Dickens, to which the latter appended the following footnote: "The conductor of this journal desires to take this opportunity of expressing his personal belief that no public servants do their duty with greater ability, humanity, and independence than the Commissioners in Lunacy." Not satisfied with this, the editor attached another disavowal to Reade's concluding number, December 26, 1863. "The statements and opinions of this journal generally are, of course, to be received as the

${ }^{1}$ See Collins's The Unknown Public in My Miscellanies. 
statements and opinions of its conductor. But this is not so in the case of a work of fiction first published in these pages as a serial story with the name of an eminent writer attached to it. When one of my literary brothers does me the honor to undertake such a task, I hold that he executes it on his own personal responsibility, and for the sustainment of his own reputation; and I do not consider myself at liberty to exercise that control over his text which I claim as to other contributions."

Contrary to his usual custom Reade did not rejoin, probably from disinclination "to quarrel with the master of us all," " though he was ready enough for a tilt with Dr. Bushnan, who attempted to defend his profession from the abuses Reade alleged in Hard Cash. Subsequently, no doubt, Reade was unsafe for All the Year Round and too expensive. The proprietor could hardly care for serials which injured his sales and at the same time rendered him responsible for opinions which he did not hold. Furthermore, Reade by this time was able to dispose of his sensational wares to more profitable markets than Dickens could offer. Dickens paid $£ 300$ for the serial rights to Hard Cash. Reade's next two novels, Griffith Gaunt and Foul Play, represent his most highly paid work. For the first he had £1500; for Foul Play £2000 from Smith of The Cornhill. The fact is that Dickens, whose sensationalism depended very little upon illicit love, did not altogether approve the younger men's much-berated novels like Griffith or Armadale. ${ }^{2}$ In February, 1867, when Reade was planning legal proceedings as an answer to the critics' strictures on Griffith Gaunt, he apparently requested Dickens, through Collins, to testify in court in favor of the book. Thus solicited, Dickens expressed the opinion, by means of a letter to Collins for

1 E. H. House, The Atlantic Monthly, October, 1887, p. 526.

2 Chatto and Windus's Edition of Hard Cash, preface. 
Reade, that the novel is "the work of a highly accomplished writer and a good man." If he were pressed in cross examination, however, he admits that he should be obliged to confess that three scenes are "extremely coarse and disagreeable." 1 Again in the same collection of letters those to Collins, collected by Mr. Hutton - we find Dickens cautioning his protégé that certain scenes in Armadale are too coarse for acting. At the same time that Dickens objects to certain scenes in Reade's story, he desires Collins to say to him "everything that is brotherly in the art."

Just where or how the friendship between Collins and Reade began neither of the latter's biographers relates; but that it was more intimate than that which existed between Dickens and Reade is perfectly clear. That they met as early as 1860, then both professional novelists of some seven or eight years' standing, is indicated by Dickens's letter to Wills previously cited. Reade's great admiration for Collins was sufficiently explicit. Coleman quotes among Reade's "obiter dicta": "For literary ingenuity in building up a plot and investing it with mystery, give me dear old Wilkie Collins against the world." ${ }^{2}$ Reade's nephew, a rather less certain guide than Coleman in matters of opinion, remarks ${ }^{3}$ that "If it were not heresy, we should almos: be tempted to hint that he reverenced the plot weaver of intricate texture as profoundly as Dickens, the incomparable humourist. This would hardly be correct, yet it may not be impertinent to add that whereas he and Dickens were on terms of friendship, his friendship with Wilkie Collins had ripened into intimacy." "Go at once and see him," he wrote peremptorily to Mrs. Seymour, on hearing of his friend's illness, "in bed or out of bed."

${ }^{1}$ Letters from Charles Dickens to Wilkie Colins, pp. 132-133; 138-140.

2 John Coleman's Charles Reade as I Knew Him, p. 265.

3 Memoir of Charles Reade, p. 343. 
That this personal interest extended to friendly criticism and suggestion, at least occasionally, in the preparation for market of each other's stories, we know from letters and prefaces, which serve to show not only the quality of this personal and professional intimacy, but its technical nature. Collins twice makes reference to the author of Hard Cash in prefatory remarks. The Two Destinies has a dedication, dated 1876, to Charles Reade which runs as follows: "You read the story while it was in course of periodical publication, and you found in it a certain novelty of design and treatment which pleased and interested you. Now that my work is completed, let me ask you to accept the dedication of The Two Destinies. I can acknowledge in no fitter way the pleasure that I feel in having satisfied my old friend and brother in the Art." Again, almost at the end of his career, in $A$ Rogue's Life, Wilkie evidently referred to Reade for suggestions about life in the Australian bush, whither he finally conducts his ne'er-do-well hero. $A$ Rogue's Life is for Collins a singularly sketchy narrative. Reade, in Never too Late to Mend, had got up material on Australia with his usual care, and had presented it entirely to the satisfaction of his public. Collins clearly intended to rely upon his friend's special knowledge in reworking a story, the workmanship of which did not satisfy him. His statement of this is dated March, 1879. "Year after year, I delayed the publication, proposing, at the suggestion of my old friend, Charles Reade, to enlarge the present sketch of the hero's adventures in Australia. But the opportunity of carrying out this project has proved to be one of the lost opportunities of my life."

Friendly criticism and suggestion did not come from Reade only, however; there is extant among the manuscripts and letters of the latter a rather elaborate series of suggestions and criticisms of Put Yourself in his Place, 
supplied evidently at Reade's request while the novel was running serially in The Cornhill. For once we may judge with some accuracy as to the nature of these interchanges. The criticism is entitled Considerations for $R$, and has in the margin a note by Reade to the effect that he was so fortunate as to please him (Collins, of course,) at last." "I start," 1 Wilkie writes, "from the December number and I say the interest in the character is so strong, the collision of human passions is so admirably and so subtly struck out that the public will have no more of new trade's unions and their outrages. They will skip pages $3,4,5$ in the November number - they will resent the return to the subject in the December number. I don't suggest the alteration of these, I only say what I say as a warning for the future. Keep to the cutlers, and keep the cutlers mixed up with Henry, Coventry, Grace and Jael, and you are safe.

"Now as to the brickmakers. I have read the report. They are even worse than the cutlers. But as an artist and as a just man you don't take the worst case for illustration. You take the medium case which may apply generally to all trade unions.

"If I had the story to finish, I should make the capitalist's difficulty in setting up the buildings for working Henry's invention arise from his knowledge of what the brickmakers will certainly do. I should make him put this forcibly in dialogue with Henry - and I should make Henry feel, exactly what a reader will feel, unmeasurable disgust at this repetition of tyranny, outrage, and murder. 'What! am I to go through it all again with the brickmakers? More conspiracies, more explosions, mutilations and deaths? That's the prospect, Mr. Little! Am I to give up my inventions; and are you to give up your profits? No;

\section{Memoir of Charles Reade, p. 343.}


we are to look out for a ready-made article in the shape of an empty building which will suit us, - and give the brickmakers the go-by in that way.'

"The building as formed in your plot - and there are the brickmakers just touched and dismissed, and the story running on again, with the setting up of the saw grinding machinery and all the incidents which follow, with this additional advantage, that Henry does not do over again with the brickmakers what he has already done with the cutlers.

"As to other points. 1. Hurry the story (if possible) to Henry's proposal to Grace to marry him, and go away with him, and to Grace's refusal. You want that strong point and that definite result after keeping the suspended interest so long vibrating backwards and forwards between Grace's two lovers.

"2. I doubt a second blowing up with gun powder. Can the necessary results be arrived at in no other way? Can it not be done by a prearranged escape of gas, for instance? Or by some other explosive or destructive agent?

"The scenes in the ruined church are so admirable and original that I want the church to play an important part in the story. Would it be possible to make Mr. Raby repair and reconsecrate it for public worship? Then to make the marriage of Grace and Coventry take place in it? And then to have the marriage invalidated by some informality in the consecration, or in the registration for marriages, of the newly restored church?

"I don't know whether such an event as this could be possible; or whether, if it could be possible, you could harmonize my idea with your notion of the uncertified clergyman?

"But it seems to me a good point to make the old church in which Henry has worked and suffered for Grace the 
retributive agent in defeating Coventry, and uniting Henry to the woman he loves.

"The first marriage celebrated in the church might be the marriage of Coventry and Grace, and so all the difficulty about the marriages of other couples might be avoided.

"Or perhaps you already mean to end the story with the marriage of Henry and Grace in the restored old church. Anyhow, I, as a reader, certify the church to be an interesting character."

This snarl of business, technical mentorship, and mutual admiration suggests the most essential bond between Dickens and his most notable followers. The chance association of Dickens and Collins through the theater, and Reade's insistence upon the drama in Boz's art are highly significant. Yet they were not imitators of each other; each had his own distinct province of this dramatic cult, his own characteristic variation of the essentially melodramatic pattern. In their own time indeed their several originalities concealed the substantial unanimity of their scheme of narrative art The similarity of Reade and Dickens, for instance, was often opined to be a moral rather than literary similarity. Such an opinion is roughly based upon the fact that both made themselves often somewhat recklessly champions of reform. But a professed moral purpose - even a reformatory thesis - is no safe distinction among the Victorian novelists. Early or late, most tale-tellers of note preached definite reform, literary, social, or religious, in the then favorite novel-shape. Trollope in Ralph the Heir and again in Chapter 12 of his Autobiography speaks of the preachment as the novelist's "snake in the grass"; Besant, in his Art of Fiction, lays down a distinct purpose as almost a canon of novel-writing; Thackeray, in the preface to Pendennis previously cited, pointedly compares the grave professor and the novelist as fellow workers. The truth is 
that the Victorians would not have been allowed, had they wished to do so, to raise the slogan of art for art's sake. Nor did they wish to do so.

As for the Dickens group, moral similarities and differences require some discrimination. However friendly in personal relations, however zealously each in his own way followed the popular fashion and made his stories explicit indictments of cheap schools, Scotch marriages, or trades unions, the dissimilarity of their views and interests upon questions apart from fiction-writing is quite as striking as the likeness. Neither Collins nor Reade had any especial interest in the poorer classes as such. Mr. Chesterton, it is true, speaks of Dickens and his followers as "hilarious democrats"; but the description wants considerable qualification. Collins personally was not a little the cynic and a great deal the man of the world. The classes whom Dickens championed with fervor are not the classes that afforded Wilkie his materials; almost invariably it is middle-class folk with whom he concerns himself; and there is little evidence that he greatly perturbed himself about the social or political future of the masses. $\mathrm{He}$ is more remote from these interests than either Dickens or Reade; and even his specifically "purposed" novels ${ }^{1}$ deal with reform in another realm - with athletics in the universities, with Scotch marriage laws, and with the dubious verdict "not proven." In a different way Collins is not less distinctly middle class in his interests and appeal than Anthony Trollope himself.

Nor is Reade less essentially different from the master than Collins, despite the excitable sympathy that in specific cases he extended to the needy and oppressed, and the emotional fervor with which his novels or letters preached the reforms in which he engaged. In this fervor and abandon

1 They generally involve questions of law, the profession for which Collins was trained. 
there was indeed a moral similarity and at the same time a difference - the similarity of absolute, absorbing sincerity for the time being, and of determination to make the world know the truth. But LReade never wrote of the lower orders of society as if he were of them, nor indeed was he. He stood consciously aloof from the persons of unlucky workmen or unfortunates wrongfully confined to asylums whose causes he championed with fervor. $\mathrm{He}$ is a jurist, a humanitarian gentleman who condescends to succor a sick cab driver with brandy. As a matter of fact he hated both cab drivers and brandy. ${ }^{1}$ And next day when the cabman calls to acknowledge the kindness the novelist is "not at home." Cab drivers, once the gentleman had performed a needed service, he remembered to be anathema; and the British workman, he thought, especially after some members of that fraternity inconvenienced him at Albert Gate, a beast. For the Sheffield workmen he had little liking; to him they were dirty and they were dull.2 His sympathies with their class are not at all the same as those in Hard Times. Specific instances apart , Reade as distinctly as George Meredith was a worshiper of "brain-stuff." It was not in their philosophy of society or of life that one must look for the essential bond between the Dickensian group. Indeed they hardly possessed any such thing. The bond is rather in the artistic aims and ideals, in their conception of narrative art, and in their belief that it affords a means of inculcating serious truth as legitimate and perhaps as efficacious as any other means available to the publicist. The common. basis of this narrative art is indisputably to be found among their random critical utterances; what it was in the words of the novelists themselves it now becomes the task to set forth.

1 E. H. House, Atlantic Monthly, October, 1887, p. 526.

2 "Builders' Blunders," article in Readiana. 


\section{Their Creed of Fiction}

I

The exigencies of the three-volume fashion were largely responsible for the circumstance that sooner or later most of the Victorians in the course of their narratives fell to gossiping upon the art of fiction. "The novelist," Bulwer remarked when he had forsaken the Cliffords and the Arams for the Caxtons, "should be a comfortable, garrulous, communicative fortune teller; not a grim, laconical, oracular sybil." This sentiment, which is notably applicable to the "low-heeled buskin" of Victorian fiction, as Trollope has it, fortunately renders it possible to discover generally in the novelists' own words the rough principles upon which they worked. Byron's famous remark about Dryden's prefaces holds true of Thackeray's incidental commentary upon his narrative, or of Trollope's, George Eliot's, or Charles Reade's. Dickens's followers especially recorded their ideals and opinions extensively, not indeed to pad the volume, but to justify their methods to the public and critics who aspersed them. Dickens himself insisted that a book ought of all things to stand by itself - that is, without explanation or argumentative justification from its author; but his less reticent juniors stood ready to take up cudgels at a moment's notice with a hostile critic, if indeed they had not already anticipated him in a preface. Consequently the ideal constitution of their romance - their favorite materials, the relation to fact, their restless experimentation, their attitude toward those of a different practice from their own - is a matter not so much of inference as of record.

The common basis of this romance is indicated in two brief statements of design by Dickens. "I always had it in my mind," he says of Little Nell, "to surround the lovely 
figure of the child with grotesque and wild but not impossible companions, and to gather about her innocent face and pure intentions, associates as strange and uncongenial as the grim objects that are about her bed when her history is first foreshadowed." 1 The concluding sentence of the preface to Bleak House insists upon the same principle in words which serve as a rough formula: "In Bleak House I have purposely dwelt upon the romantic side of familiar things." This quest of the romantic in the commonplace is the first distinction of the Dickens group. "There are places which at first sight appear inaccessible to romance; and such a place was Mr. Wardlaw's dining room in Russell Square." - So begins Foul Play, the extraordinary story of a ticket-of-leave man, a scuttled ship, and a pair of castaways in mid-Pacific which Reade and Dion Boucicault appropriated without leave from a French melodrama. The Moonstone has the same burden. Old Gabriel Betterten reflects upon the mystery in which his young mistress's jewel has involved the family: "Here was our quiet English house suddenly invaded by a devilish Indian diamond- bringing after it a conspiracy of living rogues set loose on us by the vengeance of a dead man Who ever heard the like of it in the nineteenth century mind; in an age of progress and a country which rejoices in the blessing of the British constitution?" "Wild yet domestic," was Dickens's description of The Moonstone to his sub-editor Wills in a phrase suggestive equally of his own work and that of his juniors. Dickens ransacks the slums of London, Collins searches beneath the apparently prosy exterior of middleclass life, Reade exploits the iniquities of penitentiary and madhouse - it is all one; they are all striving, as Collins remarks of some coincidences in Hearts and Science, to force realization that "not one man in ten thousand living in the

1 Preface to The Old Curiosity Shop. 
midst of reality has diseovered that he is also living in the midst of romance." There is an old cartoon of Reade which graphically conveyed this notion to periodical readers half a century ago. The novelist, in conventional costume, bestrides a pen for his Pegasus, and carries over one shoulder a pennant inscribed "imagination." $\mathrm{He}$ is mounting skyward from the dull, murky earth, which is labeled "everyday life," scattering as he goes foolscap sheets entitled Griffith Gaunt, Foul Play, and A Terrible Temptation.

For Dickens and his followers, then, romance had little to do with history. The master himself experimented with it upon any extended plan but twice, - once with the Gordon riots in Barnaby Rudge, and again with the Paris of the Revolution in A Tale of Two Cities. Reade wrought only one genuine historical novel; for the historical elements of Griffith Gaunt and The Wandering Heir, both stories of English life in the eighteenth century, are casual and subordinate. Collins never reverted to the materials of the experimental Antonina. One prime reason for thus confining romance practically to the present Reade stated cynically enough. In revulsion from the extraordinary labors demanded by The Cloister and the Hearth, he declared to Coleman that he should never attempt a similar story. "I write for the public, and the public don't care about the dead. They are more interested in the great tragi-comedy of humanity that is around and about them and environs them at every crossing, in every hole and every corner. An aristocratic divorce suit, the last great social scandal, a sensational suicide from Waterloo Bridge, a woman murdered in Seven Dials, or a baby found strangled in a bandbox at Piccadilly Circus interests them more than Margaret's piety or Gerard's journey to Rome. For one reader who has read The Cloister and the Hearth, a thousand have read It is 
Never too Late to Mend. The paying public prefers a live ass to a dead lion." 1

This variety of romance, generally taking its materials from the present, was dubbed by Reade "matter-of-fact romance." 2 It was unfriendly alike to the stereotyped traditional forms and to classical narrative. How roughly Dickens and Collins dealt with The Heir of Redcliffe because its people are conventional figures with no types in nature, embodying merely the ideals of a religious cult, we have seen. Again Collins's romantic old gentleman in the Petition to Novel Writers concludes by protesting a set of romantic formulas which he prays the story writers subsequently to avoid. This set of proscriptions, curiously enough, Collins might readily have copied from the Bulwer to whom he paid homage before he felt the spell of Dickens. The romantic old gentleman urges that it is time the hero ended drawing himself up to his full height, striding, folding his arms, riding away after the quarrel with his lady-love upon his steed; let us have an end too of the fair girl, "five feet nothing," who marries happily and of the tall dark sister whose fate is invariably tragic. Classical narrative except when exhibiting a model method, as Defoe's did to Reade, or when flavored by the thoroughgoing masculinity of the eighteenthcentury novelists, was little to their liking. Though Dickens in the fourth chapter of David Copperfield instances especially Robinson Crusoe, Tom Jones, The Vicar of Wakefield, Roderick Random, and Peregrine Pickle as youthful favorites, there is no mention of Richardson or Sterne. Like many Anglo Saxons, he found representations of classical French tragedy intolerably dull, despite his unusual love of the theater. Collins's fling at the narrative writing of the eighteenth century is doubtless expressive of the Dickensian's general

${ }^{1}$ Charles Reade as I Knew Him, p. 263.

${ }^{2}$ His definition of the term may be found in the preface to Hard Cash. 
attitude. The solution of the moonstone mystery is the result of a physician's curious experiment. As a condition for this experiment he finds it essential to keep his patient's mind absolutely quiet; and to that end provides at the crucial moment for reading matter - "The Guardian, The Tatler, Richardson's Pamela, Mackenzie's Man of Feeling, Roscoe's Lorenzo de Medici, and Robertson's Charles the Fifth, - all classical works; all (of course) immeasurably superior to anything produced nowadays; and all (from my present point of view) possessing the one great merit of enchaining nobody's interest and exciting nobody's brains."

This was the essential basis of their creed - the romance of the here and now; and the romance of the here and now was, it appeared, the essential characteristic of Victorian sensationalism. With this choice of material, however, there went professedly a distinctive narrative method. The designation "dramatic fiction" was apparently devised, or at least given currency, by Reade. His implied interpretation of it in the comment on Dickens previously quoted "novels out of which scribblers without invention have cut good plays" - is supplemented by a remark or two from his Auto-Criticism of Christie Johnstone. ${ }^{1}$ The autocriticism, as the title suggests, is Reade's own estimate of that early novel, jotted down presumably for diversion. On the title page of the novel the full name of the story runs Christie Johnstone; A Dramatic, Story. "The origin of the title," says Reade, "seems to be the amount of pure dialogue in the work." Later he remarks that the plot "is of that arbitrary kind that befits a play rather than a story." The principles according to which this arbitrary type of story was to be told we shall find recorded with considerable fulness in the novelists' own words. The few recorded opinions of Dickens, upon whose practice both

${ }^{1}$ Memoir of Charles Reade, p. 228. 
Collins and Reade built, are entitled on all grounds to priority. The rather fragmentary statements of the elder novelist are, however, considerably supplemented by those of Reade and Collins. With such a sketch of their dogma before us, we may contrast with it the position of the realists; and finally ascertain some significant influence that the dramatic cult may have had upon subsequent novel-writing.

\section{II}

There are numerous reasons why utterances by Dickens upon the art of fiction are sporadic and unsystematic. Few writers have led a busier professional life. Few, moreover, have been less thinkers about literature; and for all his confidence in himself and in his mission Dickens instinctively seems to have recognized this. He steadily disclaimed the title of critic, and advised fellow novelists generally to do likewise. "Not to play the sage or critic (neither of which parts, I hope, is in my line)" - he wrote to Collins upon the appearance of Basil in 1852, and went on to protest in some detail against the elaborate and belligerent preface his young friend had written. Even in his explanations to tyros in fiction of the rejection of manuscript stories for All the Year Round - a task which surely encourages ex cathedra, dogmatic judgments - Dickens remains not merely clear and decisive, but modest and moderate as to the grounds upon which he rules. "You will, of course, receive my opinion as that of an individual writer and student of art, who by no means claims to be infallible," he writes in refusing a proffered three-volume story. He proceeds: "Try if you can achieve success within these modest limits (I have practiced in my time what I preach to you) and in the meantime put your three volumes away." The man who wrote thus was editor of one of the most popu- 
lar miscellanies of the time and the most phenomenally successful novelist. He had in fact a settled and lifelong aversion to the customary long prefaces of the day."A book (of all things)" - he told Collins in the same letter ${ }^{1}$ about Basil - "should speak for and explain itself;" and repeated the same advice to Lord Lytton when that novelist was debating an explanatory preface for $A$ Strange Story. "Let the book explain itself," Dickens urged, at the same time indicating in it "a noble eloquence" which to him provides all necessary elucidation. Yet instinctive and unbookish as Dickens's art was, it would be the gravest mistake to assume uncertainty in his narrative creed or practice. How he wanted a story told he knew quite as well as the most philosophical of novelists; and in his capacity as editor of a periodical and mentor extraordinary to Wilkie Collins, he has recorded a sufficient number of impressions and preferences to enable some understanding of the dramatic method.

It is not singular, certainly, that in such scraps of casual criticism upon his art as Dickens left he seems to stress and require from others the peculiar devices which his own novels copiously exemplify. Let the actors carry on the story; make them do so consistently with themselves as distinct and individualized persons, not as the marionettes of a show-master; let the narrative abound in contrasts, and give it an elaborated significant background; do not reject extraordinary solutions of plot when they can be given a reasonable plausibility. All this sounds obvious, orthodox, and elementary enough. To such principles pedestrian Trollope, whose work is in principle and effect directly opposite to Dickens's, would have assented; for Trollope professed his belief in sensationalism of a kind also. It is not less in the substance of than in the stress upon ${ }^{1}$ Letters, I, p. 294. 
these elementary notions of method that the individuality of the school of Dickens lies.

Dickens insisted upon making the narrative work dramatically and was a severe critic of writers who failed to do so. "It strikes me that you constantly hurry your narrative (yet without getting on)" - he tells one aspirant - "by telling it in a sort of impetuous, breathless way, in your own person, when the people should tell it and act for themselves. My notion is that when I have made the people play out the play, it is, as it were, their business to do it and not mine." This insistence unon dramatic propriety appears again in his letter to Collins concerning The Woman in White, in which, despite his admiration for its characterization and advance in tenderness, he missed the true dramatic instinct. After specifying appreciation of its superior delícacy as compared with its predecessors and admiring the delineation of Mr. Fairlee, Marian Halcombe, and Sir Percival, Dickens remarks: "I seem to have noticed here and there that the great pains you take express themselves a trifle too much. . . . But turning to the book I find it difficult to take out an instance of this. It belongs to your habit of thought and manner of going about the work. Perhaps I express my meaning best when I say that the three people who write the narratives in these proofs have a dissective quality in common which is essentially not theirs but yours; and that my own effort would be to strike more of what is got in that way out of them by collision with one another and by the working of the story." 2 There seems to have been no other failure in narrative art so serious in Dickens's estimation as this. Certainly there is no stricture on fellow workmen's art that he presses so often, unless it be failure to master the serial design he set. To a less distinguished story-teller than Collins we find him

${ }^{1}$ Letters, II, pp. 249-250.

${ }^{2}$ Letters, II, pp. 110-111. 
once more repeating the objection. Concerning a doubtfully available story by a Miss King, he writes on February 9, 1855: "My doubts arise partly from the nature of the interest which I fear requires presentation as a whole, and partly on your manner of relating the tale. The people do not sufficiently work out their own purposes in dialogue and dramatic action. You are too much their exponent; what you do for them, they ought to do for themselves." 1 The drift of these comments appears plain. In a notable degree the persons of the story are to be made to talk, to act in their proper persons, and thus to develop a story. Dissection and analysis of character by the novelist to Dickens spells futile narrative art.

All this, plainly enough also, impliesfaccentuation of the common methods of drama and novel. The same letter previously cited - that to Mrs. Brookfield - has a further scrap of doctrine directly supplementary to these pronouncements on dramatic plausibility. The story which that lady submitted contained a death bed scene, evidently very badly written, which called for especial comment. Evidently the scene as written missed opportunities in a way that to a sensational novelist seemed grossly inept and wasteful. "Would you not say what kind of a room it was, whether it was sunlight, starlight, or moonlight? Wouldn't you have a strong impression on your mind of how you were received, where you first met the look of the dying man, what strange contrasts were about you and struck you? I don't want you, in a novel, to present yourself, to tell such things, but I want the things to be there. You make no more of the situation than the index might or a descriptive playbill might in giving a summary of the tragedy under representation." ${ }_{2}$ Such criticism means, of course, that he would have Mrs. Brookfield's scene written more
1 Letters, III, p. 162.
2 Letters, II, pp. 249-250. 
or less in the fashion of Little Nell's death or Paul Dombey's, with the wealth of detail and contrasts that his own powers of observation would have discovered in the surroundings.

Thispdemand for elaboration of the effect is supplemented in Dickens's letter to Wills concerning Collins's No Name. No Name had for its central figure a young woman brought up in considerable luxury who is suddenly deprived of her right to the name she has always borne through defective marriage laws. Through an oversight of her parents, she becomes legally and technically illegitimate. Written in the early sixties when the popular drift toward realism stories of domestic life - had compelled some modification of Collins's and Reade's original melodramatic scheme, No Name is one of Wilkie's most elaborate studies in the feminine. The story obviously presented difficulties in method, about which Dickens wrote to his sub-editor Wills that he realized the impossibility of Collins's changing greatly what he had done. "My suggestions," he goes on, "went mainly to the warning that it must inevitably come to pass that the more severely and persistently he tells the story unrelieved by whimsical playing about it the more he will detract from the steadiness and inflexibility of purpose in the girl. She cannot possibly be brought out as he wants to bring her out without it." 1 These remarks have not only their obvious place in a definition of the characteristic Dickensian elaboration of the melodrama, but they also probably explain the presence in No Name of the threadbare but scrupulously shaven Captain Wragge - a rather obvious copy from Messrs. Micawber and Montague Glass. In this matter of elaboration of effect there is by no means unanimity among the dramatic trio - at least not in the means employed. Reade's notable rejection of such sentimental pictorial ornament as is suggested by Dickens's

${ }_{1}$ Charles Dickens as Editor, p. 307. 
requirements will be noted subsequently) Yet in a wider sense which the words intimate - the desire, whether by means of pictorial description or other to realize the complete possibilities of effect - Dickens suggests the essential of Victorian sensationalism; and in this he and his followers quite agree.

The scheme of narrative that we find Dickens insisting upon, reminiscent in every detail of his own well known practice, had one more principle. Adherence to it on the part of the master and his followers has alternately amused and annoyed the critics ever since. It has to do with the adventitious in plot. How they one and all cut the Gordian knot of their difficulties - how the miraculous surgical operation permits Griffith Gaunt and his Kate to live happily ever after, how Mr. Tulkinghorn's nets about Lady Dedlock are rent asunder, how Hester Dethridge accomplishes the death of Geoffrey Delamayn - is notorious. The question came up in Dickens's own work in connection with $A$ Tale of Two Cities; there are various expressions of opinion by Collins upon the allied matter of that which transcends experience, some of which will be cited later. - The elder's puzzlement, stated in a letter to Bulwer-Lytton dated June 5, 1860, runs as follows: "I am not clear and I never have been clear, respecting the canon of fiction which forbids the interposition of accident in such cases as Mme. Defarge's death. 'Where the accident in such cases is inseparable from the passion and emotion of the character, where it is strictly consistent with the whole design, and arises out of some culminating proceeding on the part of the character which the whole story has led up to, it seems to me to become, as it were, an act of divine justice. And when I use Miss Pross (though this is quite another matter) to bring about that catastrophe, I have positive intention of making that half-comic intervention a part of the desper- 
ate woman's failure and of opposing that mean death instead of a desperate one in the streets, which she wouldn't have minded - to the dignity of Carton's wrong or right; this was the design, and seemed to be in the fitness of things." 1

The doctrine of Dickens was so casual, inconsecutive, and fragmentary that the word creed in connection with him seems at first glance pretentious and misleading. It is indeed easy to understand why criticism until recently has regarded him largely as an anomaly with few who were really kin and none who were like. With those phases of his art in which there is justification of such a view we are not here concerned. In his narrative art in the narrow sense - the manipulation of the story - he clearly insists upon the expedients in which his own stories abound. $\mathrm{He}$ is the maker of a certain variety of romance, the material of which he seeks close about him, in a narrative form carried on as far as may be by the actors themselves. It abounds in pictorial detail, studied contrasts, and startling climaxes, and is not disdainful of extraordinary intervention in the solution of plots. These things stand out as prominently in his advice to fellow novelists as in the pages of Barnaby Rudge or A Tale of Two Cities. And these devices also describe the narrative habits of his followers. Essentially upon these principles the younger men wrought a series of fictions in effect thoroughly individual, yet only modified and adapted from the Dickens creed. Inclination and circumstance made Reade and Collins considerably more loquacious about the theory of novel-making than Dickens, so that from their curious critical pieces it is possible to fill out in some detail the very general and incomplete statements of the master.

${ }^{1}$ Letters, II, p. 117. 


\section{III}

As early as Basil, it will be recalled, Collins penned a preface which Dickens opined would be better away. That preface is significant of Reade's and its author's invariable insistence upon the priority of plot in fiction, and lays down several desiderata of no less importance. "Believing that the novel and the play are twin sisters in the family of fiction; and that one is drama narrated, as the other is drama acted, and that all the deep and strong emotions that the play-writer is privileged to excite, the novel-writer is privileged to excite also, I have not thought it either politic or necessary, while adhering to realities, to adhere to everyday realities only. In other words I have not stooped so low as to assure myself of the reader's belief in the probability of my story, by never calling on him to exercise his faith. Those extraordinary accidents and events which happen to few men, seem to me as legitimate materials for fiction to work with - when there is a good object in using them - as the ordinary accidents which may and do happen to us all." The parallel of the drama, the plea for strong passions, and the defense of the extraordinary in incident find echo in Reade's dictum that "fertile situations are the true cream of fiction," and that, with these supplied, "any professional writer can do the rest." 1 What fertile situations, to his mind, are may be inferred from the context. The remark occurs in a discussion of George Eliot's methods and his own in which he declares that there are but three such situations all told in Felix Holt and The Mill on the Floss. The drowning of Maggie and Tom is one; the startling surprise scene in which Harold Tremaine learns that Jarmyn is his father is a second. Precept and example clearly incline to melodrama.

1 Bookman, 18, 252. 
Collins's phrase - "those extraordinary accidents and events which happen to few men" - is significant. It must not be supposed that they convey the romancer license to evolve the romantic stuff from the recesses of his imagination. On the contrary, with our group of fictionists, the more unusual their incidents the more certain we may be that they have authority. Reade's Autobiography of a Thief gives readers a hint on this score. "I feign probabilities," he says; "I record improbabilities. The former are conjectures, the latter truths; mixed they make a thing not so true as gospel, not so false as history - viz. fiction. ... When I startle you think twice before you disbelieve me. Distrust rather my oily probabilities. They should be true, too, if I could make them so, but I can't. They are guesses." Or again, in The Charge of Plagiarism Refuted: "Fiction is not lying, or pseudonymuncla would really find it as easy as they pretend. Let any man look into fiction scientifically and he will find all fiction worth a button is founded on fact; and it matters less than the unscientific suppose, whether those facts are gathered by personal experience, or by hearsay, or from the experience of others as recorded . . . in printed record of fact." The sub-title of Hard Cash, "A matter-of-fact romance," is defined as a "fiction built on truths - gathered by long, severe, and systematic labor from a" multitude "of sources - books and witnesses." Thus Reade contended that the novelist was not ready to produce younger than forty because he could not earlier have a sufficient mastery of fact; and then recalling that Dickens apparently offered an exception he promptly anticipates the retort by pointing out that a peculiarly hard experience of life had ripened Boz early. The method is the same whether the story like Hard Cash have an ulterior moral end, or like The Moonstone be pure mystification, or like The Cloister and the Hearth deal with 
the life of bygone times, the latter differing only in that it drives the novelist back almost exclusively to printed fact.

"I tell you," Reade goes on in the essay just mentioned, "this union of fact and imagination is a kind of intellectual copulation, and has procreated the best in fiction in every age, by a law of nature." Hence Dickens spends a season in Yorkshire before he draws the Squeers family and their establishment at Dotheboys Hall; Reade shuts himself up in Dedham Jail as preparation for the campaign against prison regimen in Never too Late; and Collins explores "the dead house" which is to furnish capital for Jezebel's Daughter. Hence, Dickens's authorities for the spontaneous combustion of Krook; the assertion of precedents for the will that makes Noddy Boffin wealthy, and for that which gives rise to the chancery suit of Jarndyce vs. Jarndyce; the defense of Jennings's strange experiment in The Moonstone, the declaration of physiological authority for the deaf mute Madonna in Hide and Seek, and the references to title and page for the occultism of The Two Destinies. This absolute and unswerving devotion to attested fact stands in strange contrast to the procedure of Trollope, who declares that when he began with churchmen like Archdeacon Grantly and Bishop Proudie he was not even well acquainted with ecclesiastics.

The reverence of the Dickensians for "fact" and their insistence upon it remind one of the impression of youthfulness that David Copperfield made upon Steerforth's valet; and though it tends to reduce truth to fact and truth to art to one and the same thing - in Reade, surely the logical conclusion of the whole matter is that the vicarious experience derived from books is hardly inferior to personal experience - it provides for the trio unanswerable justification for much that is garish, tasteless, and incredible; not only for the notorious spontaneous combustion of Krook, but for the miraculous operation which preserves Kate 
Gaunt's life and for the visions and ghosts of The Haunted Hotel. This is the justification of the reader's faith.

More than Dickens and Collins, Reade has been regarded as the champion of fact as the only true source of fiction; for he not only championed it belligerently in half a dozen controversies, but made a kind of parade of his gigantic indexes and note books in the study at Albert Gate. Thus before his death his own report and that of visitors who were permitted to visit his curious laboratory, with its mirrors, its huge stock of clippings, and its wash baskets for waste paper, had made his method notorious. Because of this system critics have frequently aligned him with Defoe. The similarity is a superficial one, inasmuch as it totally disregards the sensationalism which characterized the Dickens group. It is this sensational method which explains the radically different structure that they reared. Reliance upon fact made Defoe's lies read like truth; sensationalism made Reade's facts read like romantic lies. But Reade's devotion to the document is only slight exaggeration of an attitude in which the Dickens trio were essentially at one. If they applied their doctrine of fact childishly sometimes, it did doubtless foster new standards of 'verisimilitude for romance; for narrative built upon such a system as this, which exalts melodrama to a cult, reaches back with one hand to Mrs. Radcliffe and her followers, but forward with the other to Zola and the naturalists.

But the fashion of the fifties, with its growing predilection to the domestic, raised questions concerning such an attitude as Reade's and Collins's - notably that of the relative value of persons and plots. In the preface to The Woman in White, Collins anticipates objections which his insistence on drama seemingly implies as to characterization. His argument that the romance of the unusual necessitates no feebleness"on that score follows: "I have always held 
the old-fashioned opinion that the primary object of a work of fiction should be to tell a story; and I have never believed that the novelist who properly performed the first condition of his art was in danger on that account of neglecting the delineation of character - for this plain reason, that the effect produced by any narrative of events is essentially dependent not on the events themselves, but on the human interest which is directly connected with them. It may be possible, in novel writing, to present characters without telling a story; but it is not possible to tell a story successfully without presenting characters; their existence as recognizable realities being the sole condition on which the story can be effectively told." It is not difficult, then, to understand that Reade and Collins especially resented the growing popularity of domestic novels, for such fiction sought first of all truthful characters and considered plot almost negligible.

Therefore, even though they ultimately compromised with the new tendency, their stories contain numerous contemptuous references to the type and the methods it encouraged. Mrs. Eyrecourt in The Black Robe breaks out: "A very remarkable novel, Stella, in the present state of light literature in England - a novel that actually tells a story. It's quite incredible, I know. Try the book." "Domestic, you are aware," says Reade in a footnote to Love me little, Love me long, "is Latin for tame. Ex. Domestic fowl, domestic drama, story of domestic interest or chronicle of small beer." To the end, even after he had taken a leaf out of Dickens's book and turned didactic, Collins persists in his emphasis upon plot. In the preface to Heart and Science, 1883, there is the weariness of vain protestation upon the same score. "The two qualities which hold the highest place, in your estimation," he tells the public, "are: Character and Humour. Incidents and dramatic 
situations only occupy a second place in your favor. A novel that tells no story, or that blunders perpetually in telling a story - a novel so devoid of all sense of the dramatic side of life, that not even a theatrical thief can find anything to steal - will nevertheless be a work that wins (and keeps) your admiration if it has humour which dwells in your memory, and characters which enlarge the circle of your friends."

Nor was this hostility unwarranted; for the partisans of the domestic join issue upon all the positions of Collins and Reade. Especially Trollope's contempt for the sensational school was as great as the sensation school's contempt for him. In the foreword to The Caxtons Bulwer wrote: "It is the first" novel "in which man has been viewed less in his active relations with the world, than in his repose at his own hearth; - in a word the greatest part of the canvas has been devoted to the completion of a simple family picture, and thus, in any appeal to the sympathies of the human heart, the common household affections occupy the place of those livelier and larger passions which usually (and not unjustly) arrogate the foreground in Romantic composition." In his Autobiography Trollope describes with unusual pith the recipe for Framley Parsonage, a story which ten years after The Caxtons appeared in Blackwood's served as the opening serial for The Cornhill. "The story was thoroughly English. There was a little fox hunting and a little tuft-hunting, some Christian virtue and some Christian cant. There was no heroism and no villainy. There was much church but more love-making."

To this substitution of "the common household affections" for Collins's strong passions of the drama, Trollope again makes a general addition in the seventh chapter of his Autobiography. "A novel," he declares, "should give a picture of common life enlivened by humour and sweetened 
by pathos. To make that picture worthy of attention the canvas should be crowded with real portraits." To this denial of those unusual incidents which Collins justifies for Basil, Trollope adds: "To my thinking the plot is but the vehicle for all this; and when you have a vehicle without passengers, a story of mystery in which the agents never spring to life, you have but a wooden show." And so for his own practice he abjures mystery. In Barchester Towers, when Eleanor Bold is sought by the ne'er-do-well Bertie Stanhope and by Mr. Slope, Bishop Proudie's oleaginous chaplain, the novelist declares that, scorning to have a secret from the reader about a favorite personage, he wishes it understood that his heroine is destined for neither fortune hunter. For "whatever can be the worth of that solicitude which a peep into the third volume can utterly dissipate?" "Take the last chapter of my book, if you please... the story shall have lost none of its interest." This subordination of plot to persons found its most eloquent champion in George Eliot, the novelty of whose characters and methods was particularly obnoxious to Reade. At the beginning of Chapter 5 in Amos Barton, George Eliot answers the fancied objections of romance readers that her hero is commonplace - that he has no undetected crimes concealed in his breast and that he is not even in love. "Eighty out of a hundred of your adult male fellow Britons returned in the last census . . . are simply men of complexions more or less muddy, whose conversation is more or less bald and disjointed. Yet these commonplace people - many of them - bear a conscience, and have felt the sublime promptings to do a painful duty; they have their unspoken sorrows and their sacred joys; their hearts have perhaps gone out toward their first born, and they have mourned over the irreclaimable dead. Nay, is there not a pathos in their very insignificance - in our compassion of their dim and narrow 
existence - with the glorious possibilities of that human nature which they share. Depend upon it, you would gain unspeakably if you would learn with me some of the poetry and the pathos, some of the tragedy and the comedy, lying in the experience of a soul that looks out through dull gray eyes, and that speaks in a voice of quite ordinary tones."

Despite the misunderstandings in each party of the other's drift and emphasis, and beneath the acrimony of Trollope upon Dickens, Reade, and Collins, or of Reade upon Trollope and George Eliot, the essential differentiation between the groups is clear. 'In a word, it is plot versus character and humor; or, more accurately, a difference of emphasis upon them arising from differing narrative principles. Not less surely, for instance, would Anthony Trollope have denied the absence of sensationalism in his stories than Collins would have denied anything but an extreme care for truthful portraits in his. The sensation group piqued themselves upon the folk they called into being, and the domestic group believed as surely with Trollope in the sensational. Reade, in The Sham Sample Swindle, a reply to the charge that Foul Play is a plagiarism, discusses in detail the twentyone persons of his story, declaring seven of them creations new to fiction. Trollope's Lizzie Eustace, the heroine of The Eustace Diamonds, a flirt, liar, and thief, who achieves the double theft of her own jewels, is hardly a less sensational character than Miss Gwilt, the adventuress in Armadale. The death of Maggie and Tom Tulliver is not less melodramatic than that of Mr. Carker. The essential difference - the real distinction of the sensational manner - is that the Dickens group, instead of subordinating such incident to character interest, affect it for its own sake. It constitutes an end of narrative in itself, and the story which lacks it is, to repeat Reade's phrase, but "a chronicle of small beer." 
Such were the main prepossessions of the melodramatists who wrote the most distinguished sensational narrative of Victorian times. Their material characteristically comes from contemporary life and involves the most exciting adventures and the strongest passions in some measure for their own sake. There were, however, gradations of sensationalism. Fundamentally it consisted in an extremely adventurous story like Foul Play. As such it is merely the novel which exalts plot above character. This was Trollope's understanding of it. Usually, however, the adventurous meant the terrible, and hence the hideous motives of arson, adultery, bigamy, and murder emphasized by the Quarterly reviewer. In exploitation of illicit love as a theme, the Dickensians were not notable. Dickens himself carefully avoided it. Reade and Collins, maintaining the right to speak out as popular teachers, revealed in Armadale, $A$ Terrible Temptation, and Griffith Gaunt a tendency to follow the drift of sensational motives suggested earlier; but Rhoda Somerset in A Terrible Temptation, Miss Gwilt in Armadale, and Griffith's relations with two wives represent the only exploitation that even Victorian critics found in their tales. The proper antithesis to sensationalism is the domestic.

In short the final distinction of the Dickens group was perhaps largely rhetorical. They insist upon elaborating the scene to its full emotional value. Endeavoring to make the story work by the collision of characters, they abjure psychological analysis. They justify startling, adventitious solutions of their plot difficulties. It can hardly be pretended that these are peculiarly individual principles of romantic narrative, or that, except in the stress upon dialogue and upon certified fact, these principles announced anything unfamiliar to their own day. But the Dickensians were shrewd students of narrative methods who 
specialized a certain manner, and wrought their melodrama more precisely than others to the taste of their generation. They made a creed of familiar romantic devices, and set their folk talking with a persistency not before attempted. The product they themselves liked to call "dramatic," partly as indication of their preference for a melodramatic story, partly as designation of a method which aimed more than had been customary in the English novel to accentuate the necessary mode of fiction for the stage.

\section{IV}

Connected with the theories and ideals just outlined there are two corollaries of importance. One has to do with some modifications of the dramatic scheme effected by the vogue of the domestic, the other with the influence of the dramatic scheme upon the typical novel-length.

Between the time of Thackeray and Trollope and our own, realism, in the phrase of Professor Bliss Perry, has attained the habit of "jumping the fences" of decency and restraint in subject matter. Just as in the prose romance of the first half-century the Newgate novel followed Waverley and The Bride of Lammermoor, so after The Last Chronicle of Barset came Hardy's Imaginative Woman and Jude the Obscure. Realism was no more static than the romance. English realism sixty years ago had no dogma of detachment and no parallelism with experimental medicine. Trollope or Thackeray would have been equally surprised at such a principle as at the notion that they were not bound to tell an artificial tale. The realist indeed had a very intimate and personal interest in his fictitious children, and seldom or never, except in such a tour de force as Barry Lyndon, condescended to be a mere reporter. Thackeray, perhaps the most disillusioned of the group, took small pains to conceal 
his contempt and hatred for Becky or "the old campaigner"; and Trollope's Autobiography shows that he was quite in love with such heroines of his as Eleanor Bold and Lucy Robarts. Indeed all that Tennyson intended to stigmatize in his phrase "the troughs of Zolaism" was notably absent from the realism of Thackeray, Trollope, and The Caxtons. Trollope's reiterated boast that his novels are peculiarly English holds true of his fellow realists'. They dealt with English life on English soil, accepting and reproducing often enough the smug complacency, the insular morality at which men like Reade and Collins were up in arms, and were little influenced through the great period by foreign models. The singular fact is that the unwholesomeness which the term realistic connotes in our own day is constantly near the surface in Griffith Gaunt, A Terrible Temptation, and Armadale, but almost entirely absent from The Caxtons, The Small House at Allington, or Middlemarch.

Formally sensation romance as Dickens's followers wrote it was a transitional stage between the old time three-decker and the modern one-volume story. Although the success of Dickens's experiment with shilling pamphlet fiction and the currency of instalment literature generally spelled end sooner or later for the three-volume novel, it still remained almost the sine qua non in fiction - especially in the domestic type - through the great period. Reade alludes to this when in his auto-criticism of his two earliest novels he declares himself devoid of the "true oil of fiction." Among the novel-writing fraternity there was no secret about this requisite. In his Autobiography Trollope puts the difficulty with the utmost frankness. "In writing a novel the author soon becomes aware that a burden of many pages lies before him. Circumstances require that he should cover a certain and generally not very confined space. Short novels are not popular with readers generally. Critics often complain 
of the ordinary length of novels - of the three volumes to which they are subjected; but few novels which have attained great success in England have been told in fewer pages. The novel-writer who sticks to novel-writing as his profession will certainly find that this burden of length is incumbent on him." How shall he meet it? Trollope protests against episodes, admitting, however, the precedent of Fielding and Cervantes as opposed to his own feeling that every word should be germane. His own solution runs thus: "The painter suits the size of his canvas to his subject, and must $\mathrm{I}$ in my art stretch my subject to my canvas? This undoubtedly must be done by the novelist; and if he will learn his business may be done without injury to his effect. He may not print different pictures on the same canvas, which he will do if he allows himself to wander away to matters outside his own story; but by studying the proportions of his work, he may teach himself so to tell his story that it shall naturally fall into the required length. Though his story should be all one, yet it may have many parts. Though the plot itself may require but few characters, it may be so enlarged as to find its full development in many. There may be subsidiary plots which shall tend to the elucidation of the main story, and which will take their places as part of one and the same work as there may be many figures on a canvas which shall not to the spectator seem to form themselves into separate pictures."

In My Novel the same considerations give rise to a spirited dialogue between young Pisistratus and the amiable old pedant Austin Caxton. On the authority of Fielding, Austin favors the inclusion of explanatory, introductory chapters; but Mrs. Caxton and the young man - modernists both - object to writing which is designed only to be skipped. Austin goes on dogmatically that such a plan is 
necessary in that it is "the repose of the picture. Besides this usage gives you opportunity to explain what has gone before, or preface what is coming, or, since, as Fielding contends, some learning is necessary to this kind of historical composition, it allows you ... the introduction of light and pleasant ornaments. At each flight in the terrace you may give the eye the relief of an urn or a statue. Moreover, when so inclined, you create the proper pausing places for reflection; and complete by a separate yet harmonious ethical department, the design of the work, which is but a Mother Goose's tale if it does not embrace a general view of the thoughts and the actions of mankind." The grounds on which the art of divagation were based matter little. Learning that art, for the realist at least, was practically obligatory.

Obviously to elaboration of this sort the dramatic scheme was opposed in principle and in effect. Even in the longer early novels, Dickens's accessory material never is permitted to embrace "a general view of the thoughts and actions of mankind" as such. If he is not pushing on the story, he may be elaborating its pictorial effects but certainly not talking about the narrative or the people as one apart from them. And given his scheme of narrative it is worth noting that his unusual facility, his abandonment to the delineations of eccentrics, could furnish full-length three-deckers for but twenty years. Only once after 1859 did he attempt full length; and then upon contemporary critics the book, Our Mutual Friend, made a very general impression of laboriousness. In The Charge of Plagiarism Refuted, Reade's reply to having appropriated for The Wandering Heir materials from Swift's verse, that novelist twice puts the matter of brevity very pointedly. "Invention, labor, research and above all a close condensation to be found in few other living English novelists - all these qualities 
combined have produced a strong yet finite story (The Wandering Heir) which has fallen like a little thunderbolt among the contes à dormir debout of garrulous mediocrity." Later in the same essay he recurs to Shilly-Shally, the play which he made from Trollope's Ralph the Heir without the novelist's consent. "Mr. Trollope wrote an admirable) novel called Ralph the Heir. Everybody praised it, more or less; and nobody found a moral flaw in it; for there was none to be found. I saw gems in it that ought not to be lost to the British stage, so barren of English life, English characters, and English idioms. I dramatized and produced it. Trollope condensed by Reade succeeded with the public by a law of art, which is as inevitable as the law of gravity."

It is possible to make this matter of length more definite. The three-volume domestic novel of Victorian times ran up to 270,000 or 300,000 words. Most of Dickens before he changed his style of narrative in 1859 with $A$ Tale of Two Cities is nearer the higher than the lower figure. Martin Chuzzlewit, Nicholas Nickleby, Little Dorrit, Bleak House, and David Copperfield are not far short of 300,000 words. The Caxtons and My Novel and What will he do with it reach practically the same length. Anthony Trollope's longer stories run between the same limits; Phineas Finn and The Small House at Allington are about 270,000. Orley Farm and The Last Chronicle of Barset are slightly over 300,000. Those of the Barsetshire tales not previously included are considerably shorter - Barchester Towers, Dr. Thorne, and Framley Parsonage range from about 200,000 to 220,000. George Eliot worked toward the same bulk; Adam Bede is of about the same length as the Trollope group just cited; Felix Holt is slightly briefer than any of them. With Middlemarch and Deronda, however, she joined the 300,000word class. Now the writers who profess the principles 
of the Dickens group have a herculean task to attain such proportions. As a matter of fact they never do attain them. Dickens himself, after 1859, as has been noted, never approaches them again - except in Our Mutual Friend. A Tale of Two Cities, which he thought of especially as a tale of incident, is only about half as long as Martin Chuzzlewit and David Copperfield, and Great Expectations is something less than two thirds their length. As for Reade and Collins, though their stories appeared in three volumes uniformly enough, their average length is considerably less than that of the Dr. Thorne group. Even the reformatory tales like It is Never too Late, and Put Yourself in his Place, after The Cloister and the Hearth Reade's most extended efforts, are considerably below the 250,000 mark. His more distinctly sensational or domestic stories, say Foul Play and Love me little, scale down from 150,000, the length of $A$ Tale of Two Cities. Collins's average is less than Reade's. The Moonstone, the most complicated of the mystery stories, has about 185,000; The New Magdalen is somewhat under 120,000 .

Probably, therefore, the attribution of the generally loose and attenuated structure of the Victorian novel to eighteenth-century precedent, according to Mr. Caxton's suggestion, would be mistaken. Study of the market conditions through the second quarter of the century shows a literature forming precedents rather than following them. The tendencies in the domestic novel against which the younger sensation writers, throughout their careers, and the master at the end of his, set their faces were inherent in the primary stress upon character and humor. The outrageous price fixed by Scott upon the three-volume novel made a short novel impossible while it remained. Not unreasonably purchasers demanded a sizable book as well as a readable. The instalment plan of publication, especially the shilling 
pamphlet form, encouraged bulkiness and loose construction. The results of these conventions make clear the meaning of Collins's complaints against those novelists who fail to tell a story or blunder perpetually in doing so, and Reade's objection that George Eliot, after her kind, "uses many words whereas he after his kind uses few, or his opinion of the play he made without permission from Ralph the Heir that Trollope "as condensed by Reade succeeded by a law of nature." Whether, absolutely speaking, the younger sensation writers elected the better or the worse rhetoric is little to our purpose; at all events their example was on the side of the formally defter workmanship which subsequently prevailed in the one-volume story. 


\section{CHAPTER IV}

\section{THE NATIVE TRADITION OF TERRORISM IN THE ENGLISH NOVEL}

\section{Foreword}

THE derivation of the dramatic novel chiefly from tales about the Byronic hero implies not only that the narrative method of Dickens and his followers is essentially a native development unaltered by foreign models, but also that Scott's influence upon it was secondary. Neither generalization can pass without notice.

By the time that our triumvirate were writing, romance was no longer insular. We may recall the jibe of $\mathrm{Mr}$. Punch when he promises that his forthcoming library of sensation stories shall utilize the best brains available, whether domestic or foreign; or the example of Harrison Ainsworth, who when Jack Sheppard proved as unpalatable as Rookwood had been, essayed in Old St. Paul's and The Tower of London to dramatize a place as Victor Hugo had done in Notre Dame. What the Dickens group, especially the younger men, may have owed to the elder Dumas, Eugène Sue, Victor Hugo, and the race of lesser novelists and playwrights whom the English sensation writers of the rank and file were generally understood to have pillaged, can scarcely be ignored. Reade's admiration for the author of Notre Dame was profound. "He is a god, sir," the eccentric novelist once remarked to Coleman, in an extravagance of praise which he approaches only in speaking of Scott and 
of Dickens. Both Lèslie Stephen and Swinburne have noted similarities between Charles Reade and Victor Hugo, and Swinburne in final judgment places the English novelist between the author of Notre Dame and the author of The Wandering Jew. Balzac, on the contrary, neither Reade nor Collins admitted to Parnassus. In a long review reprinted among My Miscellanies, Collins obviously finds more interest in Balzac's improvident life than in his art as story-teller. In The Eighth Commandment Reade couples him with Fielding as "the least dramatic of novelists." Dependence upon French fiction of a kind Reade was certainly guilty of; French plays, which furnished the plots for Clouds and Sunshine, The Double Marriage, and Foul Play, he saw acted whenever he could, read constantly, and adapted for English playhouses and periodicals both with and without the consent of the original author.

Yet upon our trio, jointly and separately, the influence of French models was relatively superficial and clearly secondary. Essentially it is with English narrative traditions that we have to do. Dickens's taste, as we know from a passage in David Copperfield, was formed upon a few English models. For a professional man of letters he was unusually little the student or even reader; and his rather complacent ignorance of more than mere literature was a stock subject of reproach by contemporary critics. Moreover, Reade's addiction to French melodrama seems to have had utilitarian ends, for he clearly regarded it primarily as a repository of appropriable working ideas and themes. What Holinshed was to Shakespeare, French melodrama was to Charles Reade. Such an expression of his indebtedness, we may fancy, would have gratified the novelist greatly.

Further, the derivation of Dickens's dramatic novel mainly from stories of the Byronic hero means that Scott's 
influence upon him and his group was secondary. This opinion is by no means a denial of the priority of Scott's influence upon subsequent romance in general. But sensationalism, as the school of Dickens employed it, is a peculiar province of romance with a specialized form. It consists essentially in delineation of the most terrible emotions and the acts which those emotions excite always in some measure because they are terrible. Its materials are villainy and crime. This predilection is clear enough historically from Mrs. Radcliffe's Italian to Katherine Cecil Thurston's Masquerader, and it has tinged the whole line, sometimes more, sometimes less, with a certain unwholesomeness. To point out that the bloodiest deed recorded in Quentin Durward of De la Marck or Tristan L'Hermite exhibits little or nothing of the rhetorical lingering which characterizes say Bill Sikes's involuntary suicide or Carker's ghastly death is merely to be guilty of truism. Scott's persons and incidents are often potentially sensational enough. He was even adept at melodramatic effects; but the method and result differ essentially from sensationalism in the sense the word applies to the Dickens group because he never stresses these materials for their own sake. Sensationalism preserves an attitude toward romance - a not altogether admirable one-which Scott almost entirely abjured.

The superficial variations of this romance from the time of The Italian to that of Oliver Twist or Basil are many; but they are all clearly enough indicated in the career of the Byronic hero. He is always the central figure of a sensational melodrama; and to trace his history is to trace the rise of the method to which Dickens - in one aspect of his work Collins, and Reade dedicated their powers. The "protoplastic ruffian's" career in English fiction is a stormy one, his metamorphoses numerous, his hold upon life almost incredibly tenacious. For something like half a century in 
various guises he continued shrilly to reiterate the favorite croak of Barnaby Rudge's raven, "I'm a devil," much to the disgust of sober reviewers, and much to the delight of the generality of readers. Long before Thackeray and the Fraserians ridiculed and scourged him off the stage, he had made himself the most logical personage in English letters to have uttered King Charles's famous apology. In the novel, the character itself is of less importance perhaps than the narrative rhetoric it fostered.

It is the purpose of this chapter to trace the origins and vagaries of this spirit of romance through the work of the Dickensians. The material falls into three groups. The first has to do with the history of the Byronic hero as he affected narrative method in the novel down to mid-century; the second aims to present the composite lineaments of the dramatic novel which Dickens and his group founded largely upon the rhetorical precedent developed by experimentation with the arch villain; the last discloses the means by which Reade, who was rhetorically the extremist in sensationalism, reduced the dramatic principles of the group almost to absurdity.

\section{The Byronic Hero}

\section{I}

It is ludicrously ironical that Ann Radcliffe, almost the one novelist of a loose-speaking time who piqued herself upon her propriety, should have given birth to the singularly disreputable "Byronic" hero. If the good lady could have foreseen the ruffianly progeny for which Schedoni, the protagonist of The Italian, was largely responsible, Emily St. Aubert's consternation before the famous picture which was no picture must have paled into insignificance before her own. Clearly, however, the monstrous rascal had a fascination for her, for in the three notable stories which 
preceded The Italian - The Sicilian Romance, The Romance of the Forest, and The Mysteries of Udolpho-there are unelaborated sketches of the figure for whom her last and best story was named. The most important of these anticipatory villains is Montoni of The Mysteries, who reveals the conception enlarging and developing. Montoni, an Italian adventurer, beguiles Emily St. Aubert's aunt, Mme. Cheron, into marriage in the belief that she is wealthy. Ascertaining his mistake about the lady's fortune too late, he takes off his wife and niece, the latter practically now his ward, to his ruinous castle, Udolpho, where he forcibly detains the young woman after his wife's death. The girl being heiress to considerable property, Montoni still hopes to end his hunt for fortune successfully by taking advantage of her situation. Ultimately he makes himself into a kind of bandit king and comes to an obscure and evil end.

The portrait of the embryo Lara and Corsair is amateurish. More than once Montoni threatens to turn mere vulgar rascal upon his creator's hands without the single virtue linked to his thousand crimes. At Venice he almost degenerates into a mere gamester, and later at Udolpho he threatens to become mere voluptuary. He has the misfortune to be as clearly a woman's creation as Mr. Rochester and is about as credible as that gentleman. The burden of frightfulness which the story imposes upon him is far too heavy, so that when he would be most terrible he generally provokes only a smile. $\mathrm{He}$ is positively frightened by M. Dupont's ventriloquism. When asked by Emily by what right he detains her at Udolpho, he clanks a sword, shoots forth a terrible glance, and declares that he does so "By the right of my will."

Yet the salient characteristics of the Byronic hero are already unmistakable. Montoni is saturnine, designing, inscrutable, inflexible, lawless, and his person and mind are 
plainly meant to convey the suggestion of the mysteriously criminal coupled with a commanding personality. "His soul," Mrs. Radcliffe says, "was little susceptible to light pleasures. He delighted in the energies of the passions; the difficulties and tempests of life, which wreck the happiness of others, roused and strengthened all the powers of his mind and afforded him the highest enjoyments of which his nature was capable." Hence when Emily first meets him, she feels an admiration, "mixed with a degree of fear, she knew not exactly wherefore." The acquisition of the passion-seared face which connotes this evil genius was the final step in the finished portrait of the monk Schedoni.

Schedoni, the Italian, is really a monk, who, having made way with his brother and forced the widow to marry him by the foulest of means imaginable, takes vows in order to provide himself with sanctuary. As the spiritual director of the Marchesa Vivaldi, he opposes her son's marriage with Ellena, in ignorance that the heroine is his own niece; and finally makes a compact with his patroness personally to dispatch the girl. As he is about to do so, he perceives a miniature in her possession which leads him to think her his own daughter. In pursuance of the Marchesa's scheme to prevent an unworthy marriage, Schedoni has involved young Vivaldi, the lover, with the Inquisition. The monk is caught in his own trap. The Holy Office ferreting out his crimes, he can escape a more ignominious death only by poisoning himself.

Sir Walter Raleigh ${ }^{1}$ indicates Byron's borrowing from Mrs. Radcliffe by a comparison between the novelist's sketch of Schedoni's features and a few lines from Lara. The still life portrait of the monk runs thus: "There was something terrible in his air, something almost superhuman.

\footnotetext{
${ }^{1}$ English Novel, pp. 229-230.
} 
His cowl, too, as it threw a shade over the livid features of his face, increased its severe character, and gave an effect to his large and melancholy eye which approached to horror. ... There was something in his physiognomy extremely singular, and that cannot be easily defined. It bore traces of passions which seemed to have fixed the features they no longer animated. An habitual gloom and austerity prevailed over the deep lines of his countenance, and his eyes were so piercing that they seemed to penetrate at a single glance, into the hearts of men, and to read their most secret thoughts." As the counterpart in Byron, Professor Raleigh offers the lines:

That brow in furrowed lines had fixed at last, And spake of passions, but of passions past;

A high demeanor, and a glance that took

Their thoughts from others by a single look;

And some deep feeling it were vain to trace

At moments lightened o'er his vivid face.

The diabolical connotation of the Italian is more vividly indicated subsequently in the impression he leaves upon another's mind: "A dark malignity overspread the features of the monk, and at that moment Vivaldi thought he beheld a man whose passions might impel him to the perpetration of almost any crime, howsoever hideous. He recoiled from him as if he had suddenly seen a serpent in his path, yet stood gazing on his face, with an attention so wholly occupied as to be unconscious that he did so. It seemed as if the evil power once attributed to the eye of envious malice. held him in fascination to the monk." The parallel citations might equally well come from The Giaour, the first, as from Lara, one of the last of Byron's tales. The Giaour, the first of these oriental diabolicals, ends his days in a monastery, to the visitors of which he gives the impression - 
Dark and unearthly is the scowl

That glares beneath his dusky cowl;

The flash of that dilating eye

Reveals too much of times gone by;

Tho' varying, indistinct the hue

Oft will his glance the gazer rue.

For in it lurks that nameless spell

Which speaks, itself unspeakable,

A spirit yet unquell'd and high

That claims and keeps ascendancy.

and again

If ever evil angel bore

The form of mortal, such he wore.

Beyond this superficial bond of sinister appearance there is the fact which presently becomes important that from Montoni through Lara the connotation of the villain is rather elaborately aristocratic. Schedoni's arrogance of place as a monk is hardly less than that of Conrad the pirate whose men are his slaves. The Byronic hero is more than an aristocrat; he is a despot. The remark that his sponsor as a member of Parliament was for the people, not of them, applies with equal justice to his heroes. There is nothing democratic in their isolation, egotism, and pride of position or of race, such as Turpin's familiarity with tapsters and hostlers, or Sheppard's association with common trulls. These romantic villains are consciously aloof, contemptuous of the rabble alike by their superiority of blood, might, and passion. But between Montoni and Lara there has been a transformation. The Radcliffian figures are unmitigated ruffians, - one is suspected of wife murder; the other has achieved rape and fratricide. The final definiteness of the criminality in some measure vulgarizes them. Here Byron's tact was superior; for not only is his Giaour or Conrad a tempestuous lover, whose passion is thwarted, but Byron knew. his effects too well to resolve the mysterious blackness 
that sits upon their brows. Conrad's thousand crimes are perhaps bloody annals of piracy and revenge; we are never told. The nature of the strange sin of Manfred still has interest for the curious-minded. The superior sentimental appeal of Byron is manifest - and in his day it proved that all the world loved the lover, even though he were a Conrad.

The forces, inherent and accidental, which made Conrad and his fellows an infectious example for the first four decades of the century in English fiction, were more various than at first appears. Certainly they had more sensational qualifications than the phenomenally successful Waverley romances that shortly followed them. They were known to be the work of a young nobleman, a dangerous, mad, wicked young aristocrat; they were hailed by the reviewers as fascinating and shocking too; and before they had run their course there was a scandal about their picturesque young author that shook all England. Quite apart from the fact that they modified and reanimated a popular romantic figure, and always suggested self-portraiture of one of the most interesting men in Europe, they were admirably advertised by adventitious circumstances. How far Sir Walter Scott's words that he gave over writing verse romances because Byron beat him are sober truth, how far the generous compliment of a courtly gentleman may be a question; but that Rhoderick Dhu or even Marmion paled before Conrad and Lara is indubitable. Marmion, indeed, is an obvious enough link between Schedoni and the Byronic group. Figures render most vividly the tremendous vogue of the tales; they brought Byron from $£ 500$ to $£ 700$ each, and sold phenomenally. Fourteen thousand copies of The Corsair - or more than double the number of copies of Waverley printed in six months - were taken in a single day.

The stories themselves are terrific melodramas of love and crime, with one central character thinly disguised by 
little more than change of name. Under whatever name he appears he has suffered romantic wrongs which he has avenged, if so might be, in summary and frightful fashion; the Giaour ambushes and slays Hassan for revenging himself upon his faithless mistress exactly as the Giaour would have done had conditions been reversed; Lara murders Sir Ezzelin because he threatens to make known that Conrad the pirate and Lara the noble are one and the same, and casts the corpse into the river. Over his wrongs - not over his crimes - he broods with an intensity worthy a better cause. The striking countenance, seared by passionate rumination which stamps upon it "too much of time gone by," is the counterpart of the terrible features of the diabolical Gothic protagonist - of Ambrosio and of Schedoni, just as the mysterious sorrows that afflict him are the counterpart of their demoniac possession. The mere conception of this barbaric, amorous hero, with his lawless passions, his unscrupulous hatred, and his eagerness for sanguinary revenge, thus not only implies crude melodrama, but sets a premium upon it. The more terrible the violence, granted any adequate degree of literary skill, the more vividly successful the realization of the hero. But as the extravagance of the romantic spirit declined in the twenties and thirties, evil eye and demoniac possession became obnoxious themes to a public bent upon general education and political reform. Nevertheless, there remained eminently useful traits and themes in these tales of crime. Novelists were by no means ready to forego the sinister countenance, the isolation of spirit, the unchecked passions, and the proclivity to lawless love as Byron employed them. The consequence in the adaptations is a certain ambiguity toward breaches of the civil or the moral law.

It was Bulwer-Lytton, though he denied it stoutly, who 
was Lara's next great sponsor. The novelist was doubtless sincere enough when he not only disclaimed the allegiance, but even protested that he had done much to end the fashion Byron set. But the fashion Byron set was still very powerful indeed in fiction when Bulwer began writing, and Bulwer himself was certainly the most susceptible of the Victorians to the varying demands of popular taste. In a long and prolific. career, it is safe to say that he never disappointed or never molded it, though he often appeared to anticipate it. The example of Scott, which in a general way may be said to dominate historical romances like Devereux and Harold, clearly runs a poor second to that of Byron in the stories produced before Eugene Maltravers. Indeed the recurrence of episodes and characters which hark back to the Lara model is probably the most consistent recurrence in Bulwer's entire work. This influence is traceable as late as the Caxton series at mid-century in such episodes and persons as Darrell and his love affair, or Harley L'Estrange and his. From the earlier non-historical romances certainly an obvious descendant of "the protoplastic ruffian" is seldom absent, though it is not at all difficult to understand that Lord Lytton, the conservative of mid-Victorian days, took little pride in young Bulwer's palpable fondness for the scandalous progeny of Lord Byron. Falkland, in the early romance of that name, which the novelist suppressed; Pelham, the fob and coxcomb whose dandyism supposedly cloaks abilities amounting almost to genius; Reginald Glanville in the same story; William Brandon, the man of law in Paul Clifford; the aloof crime-crossed Aram; Ernest Maltravers in his amour with Alice - all belong to the Byronic clan, and could not possibly be what they are without the Schedoni-Corsair-Lara model.

The general nature of Bulwer's adaptation appears with less complication than elsewhere perhaps in Falkland, 
the suppressed romance. Falkland, the son of an English father and a Spanish mother, though still young and irresistible, lives a retired and solitary life as the result of an unhappy love affair. Finally he meets Lady Emily Mandeville, whom he ultimately persuades to fly with him. At the last moment her husband discovers the plan. In a paroxysm of passion and terror Lady Emily dies. Falkland, claimed by his Spanish kin in a fight for freedom, is finally entrapped and slain by the foe. The personality of the hero, the character of the passion, the romantic accessory of a fight for freedom - these show less originality than Bulwer's other adaptations. The episode of Sir Richard Glanville in Pelham is more nearly typical of this novelist's general procedure. That nobleman takes to his hearth, without benefit of clergy, Gertrude Douglas, whom he loves romantically. Called away from their cottage by the illness of his mother, he later returns to find that his mistress has been brutally appropriated against her will by Tyrrell, an acquaintance of his. He follows Tyrrell to Paris, where in disguise he ruins his adversary at play, then discloses his identity and purpose. Finally Tyrrell is murdered under circumstances which point almost convincingly to Glanville's guilt. At the last moment he is proved innocent a pleasant expedient whereby the reader obtains all the titillations that arise from the novel of crime, without wasting sympathy upon a murderer. Ultimately Glanville dies, blighted by unlucky love.

Bulwer was no servile imitator; he simply made extensive capital out of the prevailing craze for a certain type of character, just as Dickens ten or fifteen years later in Oliver Twist and Barnaby Rudge made capital out of Newgate novels. Bulwer domesticated this exotic Byronic personage and began his moral regeneration. All the Byronic episodes and adaptations previously mentioned take place 
mainly on English soil with English actors. Moreover, the one virtue of Conrad has multiplied in Aram, Glanville, and Maltravers, so that the trailing clouds of brimstone no longer oppress the atmosphere. Maltravers is platonist and poet; Aram, scholar and humanitarian; Glanville, one whose abilities might carry him to any height; Brandon, a judge who achieves the woolsack by sheer force of intellect; Darrell and Audrey Egerton, ministers of state. All are high-spirited, chivalrous gentlemen. Blighted and blighting love, in greater or less degree lawless, is the common experience of all. Maltravers and Glanville are more philosophical, if you will, than the Giaour and Conrad; but sincerity in love no less clearly in one case than the other takes precedence over the formalities of thè marriage ceremony. According to its author, Aram was intended in rather more ambitious fashion to show how crime blighted the scholar's subsequent love for Madeline Lester. Brandon outwits his false wife and sells her as his paramour to become another's mistress. So too Bulwer preserves the aloof personality; and having shorn it of its genuine diabolism, preserves even the physiognomy more or less closely - very closely in some sketches of Aram and Brandon, less so in Glanville and Maltravers. More particularly Bulwer's two romances of crime, Paul Clifford and Eugene Aram, the most famous perhaps of Newgate novels, reveal the Byronian hero in his final phase. These representative specimens make clear why and how Schedoni-Lara made his exit from the pages of the English novel.

\section{II}

The so-called Newgate romances are the final phase of the Schedoni-Lara-Aram kind of hero. Here, through an incongruous addition of virtue, he degenerates first into a 
moral ambiguity and finally turns mere vulgar ruffian in the person of Ainsworth's Jack Sheppard or Whitehead's Jack Ketch. "The Newgate novels," for present purposes, are those stories written mostly between 1830 and 1840 in which a distinguished criminal is the protagonist. They are a tentative, decadent romance owing something to Godwin's Caleb Williams, but more to Gothic diabolism and its modifications, and representing in prose fiction that want of earnestness and purpose which Professor Walker finds characteristic of early Victorianism. Here the decadent strain of the terrorists and of Byron still had potency enough to induce experimentation, but not sufficient vitality to inspire fiction of permanent worth. Rather oddly Bulwer's Paul Clifford, the reformatory tale in which Professor Cazamain finds the beginning of le Roman social, in a less praiseworthy aspect also opened a series of fictions taking their color from the tradition which has just been set forth. Paul Clifford was followed shortly by Eugene Aram and Whitehead's Autobiography of Jack Ketch. Ainsworth contributed Rookwood and Jack Sheppard. To the same appetite Borrow, Whitehead, and Macfarlane furnished biographical dictionaries of the whole fraternity of thieves, murderers, and freebooters.

The new demands for a popular literature with which men like Constable and Knight were experimenting just prior to 1830 make Newgate fiction anything but a surprising phenomenon. It is by no means certain that the bulk of stories of crime or of books dealing with it in an amusing way was greater proportionally between 1830 and 1840 than for a similar period earlier or later. Yet a variety of circumstances then served to make Paul Clifford, Eugene Aram, and their like peculiarly obnoxious and portentous. Democracy had enforced attention to popular education and amusement. The popular press in the hands of Cobbett, Hone, 
and Hetherington had inculcated opinions that seemed subversive to conservative society. Many sober men who were not merely alarmists half feared another Terror, this time on English soil; and the great periodicals were anxiously debating the desirability, the objects, and methods of general education in almost every number. Moreover, this popular novel of crime for about ten years after Bulwer put out Paul Clifford was obviously no longer a vulgar, negligibly crude thing from the Minerva Press; for Bulwer then, indeed, seemed the most probable successor to Scott's fame and influence. Not altogether absurdly serious minds felt in these notorious tales of crime a menace to both art and society.

Clearly Bulwer's two notorious romances of crime intended something far different from and superior to that which current criticism judged they attained. Paul Clifford was an onslaught upon the penal code; Eugene Aram, a tragedy of the scholar blighted by complicity in crime. The first named, declares its writer, was designed "to draw attention to two crimes in our penal institutions, viz., a vicious prison discipline and a sanguinary criminal code the habit of corrupting the boy by the very punishment that ought to redeem him, and then hanging the man, at the first occasion, as the easiest way of getting rid of our blunders. Between the example of crime which the tyro learns in the prison yard, and the terrible levity with which the mob gather about the drop at Newgate, there is a connection which a writer may be pardoned for quitting loftier regions of imagination to trace and detect. So far the book is less a picture of the King's highway than the law's royal road to the gallows - a satire on the short cut established between the house of correction and the condemned cell." Incontestably the object which Bulwer set himself, suggestive of Reade's in It is Never too Late to Mend twenty-five 
years. later, was worthy and significant; but the means by which his story is diverted in effect into a merry melodrama of outlawry are obvious enough. And the discrepancy between purpose and achievement affords a very fair measure of the power of the sensation tradition in 1830 .

The spectacle of the corruption of the young man's mind, which was incumbent on the novelist, if the pretended object of his fiction was to coincide with the real, is deliberately avoided; for Bulwer, knowing that the psychology of the situation was hardly the thing in 1830 , brushed aside that paltry manner thus: "We do not intend, reader, to indicate by broad colors, and in long detail, the moral deterioration of our hero; because we have found by experience that such pains on our part do little more than make the reader blame our stupidity instead of lauding our intention. We shall, therefore, only work out our moral by subtle hints and brief comments; and we shall now content ourselves with reminding thee that hitherto thou hast seen Paul honest in the teeth of circumstances." And therewith fails entirely in any dramatic or moral sense the first onslaught on the penal system. The avowedly reformatory novelist gives us only his asseveration for the first half of his thesis. Truly Kingsley and Reade did these things with more singleness of heart.

It was to enforce the paradox, so troublesome to the young, Bulwer says, "that, make what laws we please, the man who lives within the pale may be quite as bad as he who lives without," that the great melodramatic scene of the story was devised. Paul, the victim of social tyranny, is brought before the bar to be condemned by the wretch who cast off his mother; and the real villain, protected by his office and the approbation of the society that demands the victim's death, sits in judgment on the son whom his heartlessness has made criminal. It is hardly to be wondered 
at that this strange collocation, in which the judge, an incorruptible in his official capacity, is also the favorite passion-seared Byronic hero in a domestic setting, and the criminal at the bar, a highwayman by deliberate choice, is the real gentleman and man of honor, proved troublesome to critics; for in this highly complex and artificial juxtaposition of persons and traits, vice and virtue, as Thackeray later put it, are so inextricably mingled that it is impossible to distinguish one from the other.

These palpable weaknesses of the novelist's presentation of his thesis - the deliberate avoidance of any serious representation of the corruption of Paul's mind in the prison yard, and the incongruous theatricality of the trial scene - tell but half the story of Bulwer's dalliance. Once into the story of Paul's deeds upon the highway, the professed preachment notwithstanding, Bulwer is no less the romanticist of crime than Maturin or Ainsworth. The gusto and unction of the scene in which the hero robs Lord Mauleverer, with its stage business of Paul's coolness when his lordship essays to shoot him with a pistol from which it later transpires the outlaw has had the adroitness to draw the charge; the humorous retaliation when Clifford threatens his victim with the entire contents of the pill box which the post boy carries for the distemper evident in his lordship's attempt at murder; the magnanimous refusal of the outlaw to share the plunder which one of Mauleverer's outriders has taken independently - all this is the romanticism of highway robbery, whatever serious moral purpose the design professes. Practically Bulwer is more concerned with the manufacture of a taking story in a then popular vein than with the influence of the penal code upon malefactors. To pretend that the tale is designed and written so as to make Clifford's defense before the court a summary of the essential fortunes of the hero is idle; like Turpin in Rookwood, 
he is first and foremost a romantic gentleman of the road. The craft of the romancer is too fascinating for the purpose of the moralist; and the shifty point of view reveals the temporarily unavailing struggle of something deeper and more significant against the prevailing model of sensational romance.

Eugene Aram illustrates the same transitional aspect of the novel of crime - the perpetuation of the terrific and the unavailing struggle to turn it into worthy channels, with the consequent moral ambiguity of the protagonist. Aram, indeed, was a favorite with its author, partly no doubt because the critics detected in it the wolf in sheep's clothing. In the first preface of 1831 Bulwer emphatically differentiated his tale from the current variety of Newgate novel. "The guilt of Aram," he declares, "is not that of the vulgar ruffian; it leads to views and considerations wholly distinct from those with which profligate knavery and brutal cruelty revolt and displease us in the literature of Newgate and the hulks. His crime does, in fact, belong to those startling paradoxes which the poetry of all countries, and especially of our own, has always delighted to contemplate and examine. Whenever a crime appears the aberration and the monstrous product of a great intellect, or of a nature ordinarily virtuous, it becomes not only the subject of genius, which deals with the passions, to describe; but a problem for philosophy, which deals with actions, to investigate and solve; - hence the Macbeths and Richards, the Iagos and Othellos." The nature of the tragedy Bulwer aimed at in Aram is more explicitly stated in a later preface of 1847. "The moral consisted in showing more than the mere legal punishment at the close. It was to show how the consciousness of the deed was to exclude whatever humanity of character preceded and belied it from all active exercise, all social confidence; how the knowledge of the 
bar between the minds of others and his own deprived the criminal of all motive to ambition, and blighted knowledge of all fruit. Miserable in his affections; barren in his intellect; clinging to solitude yet accursed in it; dreading as a danger the fame that he had once coveted; obscure in spite of learning, hopeless in spite of love, fruitless and joyless in his life, calamitous and shameful in his end - surely such is no palliative of crime, no dalliance and toying with the grimness of evil! And surely to any ordinary comprehension and candid mind such is the moral conveyed by the fiction of Eugene Aram."

Nothing could be more admirable - or more nearly axiomatic; the crime of the scholar viewed in this light assuredly has as much human interest and significance intrinsically as the guilt of Shakespeare's half-barbarous king or Moorish general. That Bulwer himself believed in his achievement of genuine tragedy must be inferred from a few words of his near the end of the story. "I have not sought to derive the reader's interest from the vulgar sources that such a tale might have afforded. I have suffered him almost from the beginning to pierce Aram's secret, and I have prepared him for that guilt with which other narrators of his story might have sought only to surprise." With such explicit statement of intent, Eugene Aram forcibly recalls a certain Roundabout Paper which was to have had the simplicity of Dr. Johnson and the deep feeling of Addison. The secret of Aram in a very real sense is preserved to the end for surprise. That he has been somehow criminal a reader is, as Bulwer contends, aware, though how is a mystery; and the reader watches the net being drawn closer and closer about the hero with exactly the same kind of curiosity, though perhaps not the same degree, that he feels in following the adventures of Raffles or of Sherlock Holmes. The superior nature of the tragic material as the novelist con- 
ceived his story, and "the problem" in the destruction of the miserable wretch Clarke, which might well have fascinated a latter-day realist, are subordinated to the current model of sensational stories. The real tragedy of the situation the blight that falls upon the scholar as a result of complicity in murder - is as indistinct as in Paul Clifford is the presentation of the corrupting influence of the prison yard. The reaction upon Aram is never indicated from within; there is some mummery of broken sentences and not a little trite sketching of our familiar protoplastic ruffian - and about as much tragedy in any true sense of the word as in The Beggars' Opera. We are never in possession of his thoughts and motives until we read the confession he wrote the day before his execution. Granted the difference between Aram's story and the average chronicle of Newgate upon which Bulwer so vigorously insists, it is finally a potential rather than actual difference; and the main reason again for the discrepancy is clearly the same as in Paul Clifford.

Paul Clifford and Eugene Aram, with their moral ambiguity and trifling, end a phase of Bulwer's career. When later he drew inspiration from crime or occultism, as in Lucretia, Zanoni, and $A$ Strange Story, not domesticated Byronism, but science through its romance in alchemy, astrology, and oriental magic are his sources. Nor are Ainsworth's notorious Rookwood and Jack Sheppard, or Whitehead's once famous Autobiography of Jack Ketch significant of anything further here except as illustration of the extent and duration of the Newgate epidemic, which criticism in the complacent words of an old reviewer of Maturin found it high time to step forward and abate. From Rookwood, an avowed return to the model of Mrs. Radcliffe, and from Jack Sheppard diabolism of the Byronic caste is quite wanting. Turpin and Sheppard, as Ainsworth draws them, purport to be nothing more than common 
clay. Jack Ketch likewise introduces a set of sordid rascals who justly make an end at Newgate or in the hulks.

The novelists themselves were not altogether confident in offering such fictions to their public. We have noted Bulwer's insistence that Paul Clifford was not primarily a picture of the King's Highway and that Aram is no Newgate novel. Ainsworth's preface to Rookwood expressed a similar dubiety about Turpin. In a second preface to Paul Clifford, dated 1848, Bulwer reveals his revulsion from his Newgate stories, and pleads indulgence for the youthful mind which inspired the sentiments. "There is no immorality in a truth that enforces this question" (whether oftentimes, make what laws we will, the felon at the bar may not be a better man than his judge), "for it is precisely those offences which society cannot interfere with that society requires fiction to expose. Society is right, though youth is reluctant to admit it. Society can form only certain regulations necessary for its self-defence - the fewer the better - punish those who invade, leave unquestioned those who respect them. But fiction follows truth into all strongholds of convention; strikes through the disguise, lifts the mask, bares the heart, and leaves a moral where it brands a falsehood. Out of this range of ideas the mind of the author has, perhaps, emerged into an atmosphere which he believes to be more congenial to art. But he can no more regret that he has passed through it, than he can regret that while he dwelt there his heart, like his years, was young. ..." Meantime, however, criticism was by no means slow in reprehending the Newgate fashion to which Paul Clifford and Eugene Aram had lent distinction.

Bulwer rightly enough became the target of The Athenaeum and Fraser's, the two journals which arrogated to themselves the distinction of hounding out of popular favor the false sentiment and the obscuration of the Newgate novel. Under 
a sound demand for the rectification of the novelist's point of view in dealing with crime, the warfare, at least as it affected Bulwer, was a hilarious, blundering, scurrilous business, almost as much personal as critical. It was quite in accord with the tone of periodical controversy of the time and especially so with that of Captain Shandon and his satellites. The youthful flamboyancy of Bulwer's style, his connection with Colburn, his liberal politics, his dandyism - all offered ready targets at which the Fraserians shot with considerable more glee than accuracy. The notice of Pelham, Devereux, and Paul Clifford in June, 1830, is far from being clear-headed or significant criticism; the reviewer wastes much energy in the attempt to discredit Bulwer's knowledge of Reid, whom the novelist had referred to in Devereux, and more in picking small flaws in the motivation of Paul Clifford. The purpose of the latter story is disregarded altogether, though elsewhere it is one of Regina's objections to the writer of Aram that nothing that is is right. The good Tory journalists made serious objections to the satirical portraits of Eldon and Ellenborough as Old Bags and Long Ned, not on the grounds of their feebleness, but purely out of principle, just as the Heir of Redclyffe objected to any coloring of levity in remarks about his latelamented majesty, King Charles I. It is significant that the hue and cry against the novel of crime does not begin here. The solid objection Fraser's sought against the showy young radical was provided by Eugene Aram a year later.

The lampoons to which that novel subjected its author were followed by a sober review entitled A Good Tale Badly Told in the magazine for February, 1832. For the first time the reviewer formulates the objection to the novel of crime. He quotes Juvenal's Maxima debetur puero reverentia, and protests against "this awakening of sympathy with interesting criminals, and wasting sensibility on the scaffold 
and the jails" - for "it is a modern, a depraved and a corrupting taste." Records, he contends, show that an unusual crime is always followed by a sequence of similar offenses. Pity and terror, therefore, are not to be called upon by the novelist indiscriminately. Nor does the workmanship suit the reviewer better than the subject. Bulwer's Dame Darkmans is only a copy from Scott. Unlike the weird sisters in Macbeth or the cronies in The Bride of Lammermoor, she is not terrible, but only disgusting. Finally there is objection to "this renewed but feeble attempt to revive the stale practice of Bolingbroke, with injurious success, of combining everything venerable on earth with the ludicrous - of treating virtue and vice with equally contemptuous indifference." Voltaire and Rousseau, it is true, had powers that enabled them for a while to carry off such attempts; "but it is not for the imps of darkness to imitate the Anakims of Hell."

The principle announced, war soon followed. In August and September Fraser's published a burlesque of Aram entitled Elizabeth Brownrigge, which has much extraneous interest, inasmuch as it is very likely Thackeray's. It is dedicated to the author of Eugene Aram by an unsuccessful hack who has learned by reading that story that his own failures have resulted from his having written novels "just in character, interesting in plot, pathetic, unexceptionable in sentiment but unhappily - not of a popular description." The true popular vein is exhibited in Bulwer's story, which has taught the aspirant "to mix virtue and vice in such inextricable confusion as to render it impossible that any preference should be given to either, or that one, indeed, should be at all distinguishable from the other." Bulwer, the satirist goes on to say, is the true father of a new lusus naturae school - "Having to paint an adulterer you described him as belonging to the school of country curates, 
among whom, perhaps, such a criminal is not met with once in a hundred years. . . . Being in search of a tenderhearted .. high-minded hero of romance you turned to the pages of the Newgate Calendar, and looked for him in the list of those who have cut throats for money, among whom a person in possession of such qualities could never have been met with at all. Wanting a shrewd, calculating valet you describe him as an old soldier, though he bears not a single trait of the character which might have been moulded by a long course of military service; but, on the contrary, is marked by all the distinguishing features of a bankrupt attorney or a lame duck from the stock exchange. Having to paint a cat you endow her with all the idiosyncrasies of a dog." This is the true popular manner, and in a postscript to the tale itself the burlesquer offers to reproduce it in any number of three-volume novels that may be required. As for the burlesque itself, if it is by Thackeray, it is chiefly notable as showing how much he could improve upon it in the later travesty of the same novelist known as George de Barnwell.

The cause against Newgate fiction had found a doughty champion in Thackeray; and, if the attribution of Fraserian articles on that topic by Swinburne and Mr. Benjamin be correct, an ever ready one. Both Swinburne and Mr. Benjamin are inclined to believe Thackeray the author of Elizabeth Brownrigge, and the latter also holds the same hand responsible for the review of Whitehead's Lives and Exploits of English Highwaymen, Pirates, and Robbers in March, 1834; for Highways and Lowways, or Ainsworth's Dictionary with Notes on Turpin, a review of Rookwood, June, 1834; and for Another Caw from Rookwood; or Turpin out Again, a review of the third edition of Ainsworth's story, April, 1836. Whatever the authorship of these, in such efforts as Catherine, Barry Lyndon, and George de Barnwell Thackeray certainly 
produced the only pieces upon the Newgate controversy which have claim to permanent intrinsic interest. The record of Thackeray's activity against it is substantially then the literary history of the episode.

$\mathrm{He}$ assaulted the novel of crime generically again in Catherine, which appeared serially in Fraser's in 1839 and 1840 as a specimen in which "no man shall mistake virtue for vice, no man shall allow a single sentiment of pity or admiration to enter his bosom for any character in the piece, it being from beginning to end a scene of unmixed rascality, performed by persons who never deviate into good feeling." Catherine is an avowed rectification of the method of Paul Clifford, Eugene Aram, Ernest Maltravers, Rookwood, Jack Sheppard, and Oliver Twist, all of which are specifically mentioned as terrible examples. For this purpose he followed custom by selecting an authentic Newgate record. The true story of Catherine Hayes and her murder of her husband, as told in Whitehead's Lives and Exploits, is one of the most hideous imaginable; and Thackeray's version by no means mitigates its hideousness. "Cat" is a vulgar little drab, rescued from the almshouse by the owners of an inn to become their domestic drudge, who falls an easy prey to the soldierly person of a Prussian officer. While she is his mistress, they lead a cat and dog life. Deserted by her lover, Catherine marries a mean wretch named Hayes; and after a long time, when her first lover reappears as the wealthy attache of a foreign embassy, she plans the murder of her husband in order to be free for another amour with her Max. The crime is discovered and Catherine executed.

This delectable bit of narrative purports to come from one Ikey Solomans, who thus apologizes for introducing characters who are utterly worthless. "In this we have consulted nature and history, rather than the prevailing taste and general manner of authors. The amusing novel 
of Ernest Maltravers, for instance, opens with a seduction; but then it is performed by people of the strictest virtue on both sides; and there is so much religion and philosophy in the heart of the seducer, so much tender innocence in the soul of the seduced, that - bless the little dears - their very peccadilles make one interested in them; and their naughtiness becomes quite sacred, so deliciously is it described. Now if we are to be interested in rascally actions, let us have them with plain faces, and let them be performed, not by virtuous philosophers, but by rascals. Another clever class of novelists adopt the contrary system, and create interest by making their rascals perform virtuous actions. Against these popular plans we here solemnly appeal. We say, let your rogues in novels act like rogues, and your honest men like honest men; don't let us have any juggling and thimblerigging with virtue and vice, so that at the end of three volumes the bewildered reader shall not know which is which; don't let us find ourselves kindling at the generous qualities of thieves, and sympathizing with the rascalities of noble hearts. For our part, we know what the public likes, and have chosen rogues for our characters, and have taken a story from The Newgate Calendar which we hope to follow out to edification. Among the rogues, at least, we will have nothing that shall be mistaken for virtues. And if the British public (after calling for three or four editions) shall give up, not only our rascals, but the rascals of all other authors, we shall be content - we shall apply to Government for a pension, and think that our duty is done."

When Barry Lyndon, a serial for Fraser's in 1844, and George de Barnwell, a contribution to Punch in 1847, were written, critical opprobrium had long since forced Ainsworth and Bulwer to relinquish criminal romance. Properly speaking, these efforts hardly belong to the critical contro- 
versy. Thackeray had long ago achieved the object of his campaign; but he probably felt that Catherine was too purely temporary and journalistic in its appeal, and designed Barry as an effort in carrying out the principles he had preached. Its workmanship, critics have generally agreed, is not inferior to that of Esmond. Almost equally brilliant is the burlesque George de Barnwell. The appropriation of Lillo's title, augmented by a de in memory of Bulwer's fashionable novel Pelham, provides the proper connotation for a wholesale satire of the absurdities and obliquities of the early Bulwerian romance. From the grandiloquent meaninglessness of the opening sentence to the benevolent Fuzwig's last gentle corrective to the condemned George "The Tragedy of Tomorrow will teach the world that Homicide is not to be permitted even to the most amiable Genius, and that the lover of the Ideal and the Beautiful, as thou art, my son, must respect the Real, likewise" - the likeness never fails, the point never dulls. The pseudolyrical twaddle of the prologue; the first display of the future murderer as a grocer's boy ecstatically reading Homer in the original behind his counter while an impatient customer clamors for a half-penny-worth of tea dust; his entry through robbing the till into the polite world where he beats Addison both at toping and at writing numbers for The Spectator, suggests an emendation for Pope's Homer, caps Dean Swift's verses, and impresses the Secretary for Foreign Affairs with his intimate knowledge of French language and politics; the ruminating defense in the condemned cell for ridding the world of a man whose soul "never had a feeling for the Truthful and the Beautiful" comprise a composite of the extravagance, pretentiousness, and cant of Pelham, Devereux, Paul Clifford, and Eugene Aram so like that it might readily pass for skillful paste and scissors work upon them.

From 1830 to 1840, already mundane enough, The New- 
gate Novel reveals a triviality and obscuration in the narrative presentation of crime arising in part from deference to a decaying popular romanticism, in part from the want of satisfactory models and serious object. It fed an unwholesome taste which the times made rampant by reliance upon a decadent tradition, and minimized the axiom as to the wages of sin. Aram, Turpin, and Jack Sheppard are grudgingly turned over to Jack Ketch in the end; but "the last indignity of the law," to quote Bulwer's euphemism for the execution of Eugene Aram, is typically only a mischance which puts an end to the adventures of an attractive scamp. It reveals not a soul caught in the meshes of crime, but a bandit who is the soul of honor, or a murderer so kindly that he turns aside rather than crush a worm. Parody and savage derision from the reviewers undoubtedly hastened the passing of this maudlin, ambiguous sentimentality; new and better impulses - the eccentric portraits by Dickens, the services which the novelists perceived their medium might be made to afford in reform, the growing tendency toward domestic fiction - must soon have suppressed it regardless. Again it altered in ways which it is not our business here to follow. What, for example, Poe may have owed it, how Bulwer altered and adopted it in Zanoni and A Strange Story, "are interesting questions, and not past all conjecture." This novel of demons, housebreakers, hangmen, highwaymen, and murderers did foster a serviceable method - that of the accented melodrama of the school of Dickens, the high achievement of Victorian sensation fiction.

In Oliver Twist, with its Fagin, Nancy, and Bill Sikes, in Barnaby Rudge, with its episode of the hunted murderer, in Wilkie Collins's Basil, with its diabolical Mannion, and in It is Never too Late to Mend, with its entire narrative of Tom Robinson, the pickpocket, the indebtedness of the 
Dickens group in their early successes to the story of crime is apparent. Thackeray, it will be remembered, found the kinship of Oliver Twist with that disreputable fiction sufficiently unmistakable to include the story for especial reprehension in Catherine. The relationship in Barnaby, as in Oliver Twist, is very simple. Barnaby was written under the most trying conditions imaginable. Its author was under contract to Bentley at the time to produce three full-length novels. Barnaby Rudge, a piece of task work, naturally then, shows indebtedness to the current popular model; one has only to read the introduction of the murderer Rudge at the Varden inn or the final scene between him and Mr. Haredale to comprehend the models upon which Dickens worked.

The preface to Oliver Twist puts beyond all doubt its derivation from the tradition of diabolism and ruffianism. Its professed theme is the hideousness of crime; a theme in which the writer clearly thought of himself as a reformer of degenerate romance. After a passing reference to the strictures made upon Oliver when it was appearing in periodical form, Dickens proceeds to justify himself exactly upon the grounds of the rectified point of view. Having found in all books of his acquaintance which deal with the criminal that "certain allurements and fascination are thrown about" him, he believed that to draw "a knot of such associates . . . as really do exist; to paint them in all their deformity, in all their wretchedness; to show them as they really are, forever skulking uneasily through the dirtiest paths of life, with the great black ghastly gallows closing up their prospect," was to attempt something greatly needed in art. Then, glancing at the squeamishness of novel readers generally, he remarks: "It is wonderful how Virtue turns from dirty stockings; and how Vice, married to ribbons and a little gay attire, changes her name, as wedded ladies do, 
and becomes Romance." That he or his followers owed anything considerable to so despicable a set of fictions as they would have felt the Newgate novels to be, they would probably have denied stoutly; but the Newgate novel, as the descendant of the diabolical in earlier romance, encouraged and perpetuated a narrative method - the melodramatic method of terrific effects consciously wrought for their own sake. It was a way - it was the way - of telling a story of adventure, no matter whether the setting were the wretched garret of Fagin, the King's Highway, or the comfortable, well ordered home from which Rachel Verinder's oriental jewel disappeared.

Its materials were transitory and shifting. The main transitions of its fashion in materials are not difficult to date approximately; by 1820 or 1830 the supernatural had practically expired; by 1840 the Fraserians had practically hooted the decadent Byronism of Newgate novels off the stage; at about the same time, the rise of Dickens closed the ascendancy of historical novels after the fashion of Scott. But the method for better or worse remained a permanent possession of the novelist, and one that for obvious reasons can never for long fall into disuse.

\section{The Common Characteristics of the Dickensians}

\section{as Sensationalists}

Dramatic fiction, as Dickens's followers were fond of designating their melodrama, was thus subjected to several influences. Something it owed to the sensational tradition stretching back to Mrs. Radcliffe and the Gothicists, something to the group's common devotion to the theater, and something to the practice of serial writing. From the novelists' own utterances it is apparent that the term signifies both a method and a kind of material. It is avowedly a 
romance of the here and now, based upon unusual but attested fact, and distinguished, like all sensationalism from the time of the terrorists, by a preference for the strongest emotions that men know or can conceive. Methodwise it is notable for repudiation of the dissective quality which is a property of the writer, not of his fictitious personages, and for the admission of extraordinary solutions of plot difficulties.

From the high selectiveness inherent in such a scheme of narrative it necessarily follows that each effort requires and exhausts a relatively rare, dynamic idea. A Trollope may dog Plantagenet Palliser through half a dozen three-volume tales from early boyhood to old age. George Eliot will find a recompense in delineation of the dull gray soul mainly for its undistinguished neutral color; but the dramatic novelist's scheme burns material with a profusion none but the prolific can afford. The romancer who is fortunate enough to hit upon the idea of Peg Woffington, the woman of many lovers taken by the unpracticed country gentleman, whose unsophistication is the key to his success; or upon that of The Moonstone, in which nervous excitement and a surreptitious dose of opium produce an unfathomable mystery, can never recur to it or to any recognizable variation of it. It is among the things that are achieved and concluded. Fifteen years ago, when M. Rostand's romantic comedies were fascinating theater-goers, Henry James concluded a review of them with the advice that the author of Cyrano come over and join the realists; for, says he, how long can M. Rostand go on fishing out of the romantic sea conceptions such as the tragic contrast between Cyrano's hideous nose and his poet's soul, or such as that between the aspirations of the young man born in the shadow of a great name and his environment? Realism is surer, Henry James concludes; and what, if Rostand would but 
see the light, could he not do with ingenuity and style such as his! Reade and Collins were keenly aware of the difficulty. In Hard Cash Reade makes the eccentric Dr. Sampson rebuke current fiction as "unidead melodrams for unidead girls"; and in A Terrible Temptation he pointedly distinguishes his own from the generality of novels because they are, in his favorite word, "idead." He told his American publishers that "the public goes for a book with a feature." So Collins reiterates the purpose in Poor Miss Finch, say, of extending his studies in fiction; a recurring expression in his prefaces by which he calls attention to the variety of "ideas" upon which his own melodramas are founded.

This constant experimentation necessitated by the melodramatic creed appears clearly even in a rough list of Collins's themes. Basil dealt with a man's marriage to an unworthy woman; Hide and Seek exploited the deaf mute Madonna as heroine; The Dead Secret, The Woman in White, and The Moonstone were studies in mystification on slightly different plans; No Name depicted the struggles of a girl, gently reared, upon the legitimacy of whose birth doubts are suddenly cast; Armadale presented the adventuress at full length; Man and Wife attacked Scotch marriage laws and athletics in the Universities; The New Magdalen portrayed the wronged woman's effort to regain footing in society; Poor Miss Finch drew the blind girl according to fact; The Law and the Lady demonstrated the evils latent in the Scotch verdict "not proven"; Jezebel's Daughter centered in a poisoner possessing the secrets of the Borgias; The Black Robe dealt with the machinations of the Jesuits upon wealthy Englishmen; The Two Destinies was based upon telepathy, and Heart and Science attempted to demonstrate the insufficiency of science to develop humanity or humaneness. No Victorian perhaps had a better right to the dis- 
tinction which Bulwer liked to claim - that of interesting through a constant, studied variety - than Collins.

His "brother in the art" was scarcely less varied. Peg Woffington was the ideal presentment of the great actress and her contemporaries on the stage; Christie Johnstone, a realistic study of the Scotch fisher folk; Never too Late to Mend, an assault upon the prison system; Hard Cash another upon the asylums; The Clorster and the Hearth, a panorama of Renaissance Europe; Love me little, Love me long, a domestic story portraying what Mr. Howells calls "the coquette manquée" in Lucy Fountain; Griffith Gaunt, a psychological study of jealousy cast in outrageously sensational form; A Terrible Temptation, the story of a family feud, involving the metropolitan auctioneers and builders, and exploiting the kept mistress; A Simpleton, the evils of tight lacing; and $A$ Woman Hater, the misogynist's capitulation to the opera-singer. Reade, in fact, even when jaded and least himself, as in The Wandering Heir or The Woman Hater, had always fished in what Henry James calls the romantic sea to some purpose. The notion of an heiress who travels across seas and upon another continent in male costume, or of the woman hater who finally takes to wife the stage woman, savors little enough of inspiration, no doubt; but Dickensian melodrama abounds in conceptions more banal. The typical Readean idea was a thesis, and however much it might be distorted by reckless enthusiasm, the dynamic idea was almost invariably there.

Dickens's themes hardly reveal the combined flamboyancy and novelty that are apparent in Reade and in Collins. Such conceptions as that of The Old Curiosity Shop, in which a little girl becomes the guardian spirit of a senile gamester, or that in Great Expectations, in which a wretched orphan boy befriends a convict who in turn sets up the lad as a gentleman in London, are not representa- 
tive, Generally, the excitements in Dickens's stories appear less desperately and laboriously studied than those in Foul Play or The Moonstone. Usually he is nearer life than his followers and more representative of it how realists like Gissing and Mr. Howells may reprehend his unreality. He descended to banalities often enough: his satellites hardly condescended to human probabilities. The reason for the difference perhaps is that whereas Dickens had amassed a huge stock of useful sensational material from observation and experience, Collins and Reade must needs go farther afield. If the elder novelist chose to write about the murder in Seven Dials or the strangled baby found in the band box at the Picadilly Circus, he was not obliged to eak out his plot, as Reade with his indexes did by means of newspaper reports of crime and violence from the ends of the earthy The novelty of Reade's melodrama and of Collin s resided in their Iaboratory method; the skill of Dickens's in the facility and fertility of incident, the comic business, and the decorative description of his scene

The pattern which each dramatic novelist evolved from this central doctrine of strong passions pictorially represented had distinctive individuality. In general terms the Dickensian recipe from Oliver Twist to Edwin Drood was melodrama! plus grotesque and humorous character elaboration. These ingredients are, however, by no means constant in their proportions. After 1859, when the labors of over twenty busy years demanded a conservation of his powers, Dickens set about devising "stories of incident. This is the phrase he chose to describe A Tale of Two Cities. Examination of the four novels written between that time and his death reveals a considerable diminution in bulk, Our Mutual Friend being the only one to approximate the conventional three-volume length. This reduction has been achieved, not 
by the entire elimination of "character parts," - for Mrs. Gargery, Cruncher, and "the aggerawayter," with her untimely prayers, are off the same piece as Mrs. Gamp and Captain Cuttle - but by the subordination of the eccentrics to a stricter narrative unity. Dickens and his favorite pupil Collins are changing places. Dickens writes The Mystery of Edwin Drood, and Collins, the past master of mystery stories, writes Man and Wife, a reformatory tale with a double thesis. In general down to 1859 a novel by Dickens consists of a loosely constructed melodrama or two, ${ }^{1}$ and exuberantly garrulous scenes for characters ad libitum.

The younger men have nothing to parallel the inimitable's grotesques. Collins, structurally the greatest master, deals with a single unified plot, all the ramifications of which are so carefully exhausted as to reduce his persons to automata. Only occasionally in Bishopriggs, the rascally serving man in Man and Wife, in Hester Dethridge of the same story, in Gabriel Betterton, the servant of the Verinders in The Moonstone, and in Count Fosco does he rise above this limitation. His unique narrative mastery appears strikingly in Man and Wife, an unnoticed tour de force hardly less notable in its way than Barry Lyndon. In this reformatory tale, which Swinburne ranks next to the two great mystery stories, Collins employs the stage nomenclature of which he was fond. It is divided into prologue, epilogue, and sixteen scenes, each of which observes the necessary stage condition of being enacted in a single place. Its mechanics may not reveal imaginative genius, but it is

${ }^{1}$ Barnaby Rudge is practically a double melodrama consisting of the Haredale murder story, a modernized tale of terror, and the Joe and Dolly Varden story. In Bleak House Jarndyce and Jarndyce give loose connection to several stories including that of Rick and Ada, Esther's love story, and the banal tragedy in "high life" of Lady Dedlock. 
perfectly safe to say that none of Collins's contemporaries could have constructed it. In contrast to Collins's elaborately exhaustive unity, Reade's typical scheme consists in the compression of several melodramas between two covers. More than any of his fellows he aimed at swiftness, compression, and frequent startling dramatic effects, his ideal apparently being to impart a distinct thrill to every chapter. There are two consequences of this effort; among important English novelists there is perhaps none who equals Reade in celerity and in the quick succession of emotional thunder claps; again, in order to attain the conventional three-volume length, he is forced to rely not upon one strand for plot, like Collins, but upon several.

There is another notable difference between Collins and Reade. The latter's vigorously masculine mind found no interest in mysteries which experience cannot resolve. $\mathrm{He}$ abominated the unintelligible with all the fervor of men in the age of prose and reason. His plots, therefore, from Peg Woffington to A Perilous Secrel are all essentially straightforward, obvious, physical melodrama. The occult of The Two Destinies, the fatalism of Armadale, and the ghastly supernaturalism of The Haunted Hotel his unspeculative mind never dallied with. His thrills and horrors are honest, mundane thrills and horrors based upon gunpowder, flood and storm, pirates and fights against odds such as Gerard's and Deny's in the old French inn, or Henry Little's in the old Cairnhope church. He makes none of that demand upon the reader's faith of which Collins speaks in his preface to Basil, but sticks to the stock agencies. His melodrama aims at the matter-of-fact intelligence of the gallery gods and never can puzzle them.

${ }^{1}$ Never too Late comprises three stories; Hard Cash, two; Put Yourself in his Place, two. Others, except The Cloister and the Hearth, do not attain the conventional length. 
Underneath these minor divergences of temper and pattern stand the common and characteristic devices of their sensationalism, notably the preference for strong passions because they are strong passions, which found expression in 1800 in Terrorism, and a century later in shilling-shockers; and also a deliberately external method in character delineation here consciously and deliberately adhered to as the preferable way of telling a story., Collins's failure in the latter, it will be recalled, was Dickens's single source of quarrel with The Woman in White. Reade reiterates the same principle in both Love me little, Love me long and Griffith Gaunt. In two words, if the expressed opinions of the Dickens group have meaning at all, they imply intensity for its own sake and externality of method.

More concretely still, intensity means the extraction of the last possible emotional thrill; externality, avoidance of psychological dissection, in favor of a representation of persons in an unusual degree by means of gestures, words, and acts. The dramatic novel is thus a novel of coarse, strong effects, drawn in black and white with few neutral tints, and so bristling with sensationalism that the reader is never meant to see out of its romantic bamboozlement. Making 'em laugh, cry, and wait was for the Dickensians the quintessence of "the cheap yet ravishing delight" which Reade defined fiction to consist in A momentary glance at Griffith Gaunt and Romola serves to illustrate the characteristic differences between them and the realist group. Both tales deal with the alienation of husband and wife; but the very opening of Reade's story, with its snatch of sensational dialogue, is sufficient index of the garishness to come. Here duels, bitter domestic quarrels, drowning, a woman pleading her own case in trial for murder, and bigamy are the mainsprings of the action. Set off against these the subtle steps in the disaffection of Romola and 
Tito. The wronged wife gives the key in her remark that "harsh words between those who have loved are hideous," and so the tragedy develops in silence through the quieter agencies of the unexplained coat of mail beneath Tito's doublet, the sale of the old scholar's library, which sentiment should have preserved, Romola's knowledge of her husband's relations with another woman, and the presence of the mysteriously dependent old man, Tito's unacknowledged father.

The dramatic group's method as illustrated in Griffith Gaunt has continued to be a steady point of attack for lovers of realism from Thackeray's time. Mr. Howells, for instance, cites as typical of Dickens's theatricality Nance's death at the hands of Sikes and the scene between Edith Dombey and Carker at the French inn. His comparative judgment of Boz and Reade is that both are of the theater, but that the younger is of the better theater. Mr. Dawson, a critic with less animus against melodrama, notes that Reade is forever ringing down the curtain upon a climax. From one point of view Mr. Howell's comparison holds, from another it does not. Reade's unparalleled prodigality of this effect has been illustrated previously. As to rhetoric Mr. Howells is quite correct. "The mawkish," Reade truly declares in Hard Cash, "is a branch of literature I have resolutely avoided"; and the rhetorical excesses of the passages 'Mr. Howells cited were certainly quite foreign to the Readean vein. Collins with equal truth might have pleaded the same exemption.

Surprise, coincidence, fortuitous retribution - these overinsistent characteristics of the dramatic novel in its high spots have largely discredited its narrative art in our own day of more sophisticated methods. Gissing, a thorough Dickensian, remarks of coincidences in Dickens, that, down to the time of Bleak House, "It never seems to have occurred 
to him thus far in his career, that novels and fairy tales (or his favourite Arabian Nights) should obey different laws in matter of incident"; ${ }^{1}$ and the judgment holds good for Our Mutual Friend, the last of the full-length novels. That this is typical of the group is apparent enough. In Never too Late read the scene in which George Fielding returns from Australia just in time to prevent his sweetheart's entrance into the church in order to marry his villainous rival, or in Foul Play the way in which Wylie, who scuttled the Proserpine, hides his blood-money in the one room in London in which there is the man with the motive and the means for tracing those bank notes. The plots for Foul Play, Griffith Gaunt, and Poor Miss Finch involve coincident circumstances which affect the whole story. In the first, Penfold, condemned for forgery, takes service as ticket-ofleave man with the father of the girl who is in love with the forger whose crime transported him. In Griffith Gaunt and in Collins's story each hero has a double, Reade's serving to bring Mrs. Gaunt to trial for murder, Collins's to complicate an almost incredible love story. The dictum that the contrived story led Dickens into melodrama is reversible. Upon the showing of precept and example, admiration for melodrama was a prime reason for the Dickensian's preference for the contrived story.

In nothing perhaps is their determination to put human emotions to the rack more apparent than in theirlexcessive use of fortuitous retribution. Before limning the ghastly sketch of Quilp's corpse washed about in the muddy tide, Dickens remarked: "Retribution, which often travels slowly, especially when heaviest, had tracked his footsteps with a sure and certain scent and was gaining on him fast. Unmindful of her stealthy tread, her victim holds his course in fancied triumph. Still at his heels she comes, and once ${ }^{1}$ Charles Dickens, A Critical Study, p. 69. 
afoot is never turned aside." Generally enough indeed the emotional pace of the dramatic novel is so tremendous that mere human agencies are feeble, and Heaven is invoked to smite the wicked. Quilp and Steerforth are drowned; Bill Sikes is an involuntary suicide; Rigaud Blandois is crushed to death in a falling building; Carker is ground to atoms by a railway train; Mme. Defarge is disposed of by an accidental discharge of a pistol; Sir John Chester's wickedness exacts the life of the son, as does Ralph Nickelby's ignoble revenge upon Nicholas. Reade's and Collins's lists are hardly less formidable. Mention has been made of the infuriated sailor in Foul Play whose attack upon Helen Rolleston is swiftly punished by making him food for the sharks. Coventry, the rascal in Put Yourself in his Place, suffers paralysis; Severne in The Woman Hater drops dead; Wardlaw, the forger in Foul Play, becomes an incurable maniac; Mannion, the diabolical enemy of Basil, ends his malignant pursuit of that young man by falling from the cliffs into the ocean. In Heart and Science a coincident discovery of the medical secret upon which he has labored for years leads Benjulia the vivisectionist to a ghastly suicide. By coincidence, also, Delamayn's overdevotion to athletics brings down the long-threatened paralysis at the moment he is about to become a wife murderer. In Armadale, the adventuress, caught in her own gin, is the victim of poison intended for another.

These exactions of the moral order in terms of the charnel house were not intended merely as dexterously manipulated, crude horrors. They illustrate an eternal verity - if we accept, as the Dickensians did, Collins's preference for those unusual events that happen to but few of us. It is a coincidence in which we are to see the hand of providence that Steerforth's dead body is cast up on the Yarmouth sands in sight of the home he had dishonored. The fate of Bill 
Sikes, of Delamayn, and of Wardlaw represents the same intervention. When Reade's forger is smitten with incurable mania, Penfold, his hero, is made to remark: "I have not forgotten who said "Vengeance is mine" "; God's still in his Heaven and all's right; and shall He not visibly take a hand in punishing the Severns and Benjulias whose crimes human justice visits so weakly? That $\mathrm{He}$ should do so was not less in accord with the Dickensians' narrative art than with their theology. The fact that all this was good theology, indeed, made it good narrative art. Indeed there are no novelists so "moral" as these Victorian sensationalists, unless it be the dime novelist, who is descended from them.

The doctrine of strong passions pictorially represented results in a characteristic difference in incident between the dramatic and the realistic group. Trollope, as has been indicated, expressed the opinion that fiction should abound in sensationalism, and illustrated it copiously enough in practice. Phineas Finn, the Irish Member, fights a romantic duel and is involved in a mysterious murder. Lizzie Eustace, in The Eustace Diamonds, after stealing her own jewels, plays very interestingly at hide and seek with the police. Vavasour and Grey, the rivals for the heroine's favor in Can you forgive her? engage in a shooting affray. But this sensationalism, according to Trollope's ideal, is always subordinate to character interest. Moreover, as he makes one of his heroines remark, in words that are expressive of the realistic attitude before the example of George Eliot was greatly heeded, "I shall never go beyond genteel comedy." "Genteel comedy" avoids, of all things, melodramatic heroics. John Eames, Becky, and Pendennis are sworn to no romantic-dramatic creed, and their creators are apt to dash their protagonists' finest efforts with an unheroic spice of the ludicrous and ironical. Poor Pen cuts a sorry figure before his lady-love in an altercation with an amorous 
cook. Johnnie Eames is shamefaced about his great exploit of thrashing the man who jilted Lily Dale. John Grey, with all romantic right upon his side, sets about throwing Vavasour, the miserable sponger on his sweetheart's fortune, out of his chambers; but the result is a very equivocal triumph - a very imperfect realization of heroism and poetic justice - when Grey, badly tousled and bruised, discovers that his late adversary's hat has been left behind in the scuffle. The last touch of the ludicrous comes when Grey casts the hat into the hall below, where his enemy is still spluttering and menacing. It is not thus that Nicholas or Henry Little emerges from a fight.

Nicholas resents Sir Mulberry Hawk's light use of Kate Nickleby's name with a riding whip, laying open the rake's cheek from eye to mouth. For good measure, Sir Mulberry's bolting horse throws him and breaks the master's leg. When we hear of Sir Mulberry again he is confined to his chair, "with a shattered limb, a body severely bruised, and a face disfigured by half-healed scars." When Mr. Merdle, the high financier of Little Dorrit, commits suicide at the baths, the pen knife he employed is prominently displayed, as is the vivid blood stain against the white enamel. So after Mr. Carker has stepped in front of the oncoming express, we see the sniffing dogs being driven from the fragments of flesh and bone, and the operatives drying the pool with a train of ashes. The realists offer tolerably close parallels for these incidents. Like Mr. Merdle, Melmoth in Trollope's The Way We Live Now is a financier whose forgeries end in suicide. Like Nicholas, John Eames chastises a man for shameful mistreatment of a woman; and like Carker, Lopez, another Trollopian protagonist, is ground to death beneath a railway train. Melmoth, whose villainies are as egregious as Merdle's, goes home like a decent burgess when the game is played out and discreetly makes 
an end with prussic acid. A line suffices. Johnnie Eames, not less ashamed of than elated by his prowess in blackening the dastardly Crosbie's eyes, suffers some very human qualms in fear of the bobbies and the police court. Lopez is crushed to "a thousand atoms" at the Tenway Junction; but there is no spectacle of dogs sniffing blood, nor of workmen ostentatiously scattering ashes. The circumstantiality of Dickens's rhetoric and its utter abandon his satellites did not copy. Reade never dawdled over his terrific effects. His distinction, however, is in brevity rather than in reticence, like the brutal curtness of the description of the injured workman in Put Yourself in his Place as "a bag of grease and bones." In taste Collins's rhetoric was superior to his master's also; but the unforgettable parts of Collins's novels - both persons and scenes - are studies in the grotesque and terrible; in persons such as Hester Dethridge and Count Fosco; in scenes such as that of Rosa Spearman beside the shaking sand-flats, the ghastly death of Benjulia, and the laboratory episode of Armadale.

Not only was the dramatic method particularly insistent upon realizing the full emotional value of the incident; it was also external by choice. The practice of presenting character primarily from within was the peculiar contribution of George Eliot; and was in a sense undeveloped before her. It will be recalled that Bulwer in Paul Clifford deliberately rejected the psychological reactions where they were essential to any complete or vital exposition of his thesis upon the grounds that readers found them dull. In one way then the deliberate externality of the Dickensian group was reactionary and looked backward, though with the essential difference that such procedure was part of a deliberate creed of art. There were two tendencies in the style of fiction corresponding to the two main ideals of its purpose - that of drawing "real portraits," in Trollope's 
phrase, and that of presenting strong passions dramatically. The two extremes are George Eliot and Charles Reade. The plain tendency among the realists is to gravitate toward the method of Daniel Deronda, let us say, 'where George Eliot's preoccupation with mental processes begins to overshadow other considerations; among the dramatic group toward the method of Peg Woffington, a novel consisting of the dialogue of a stage piece slightly elaborated.

Almost any one of the emotional scenes from Dickens that have been mentioned - those from Oliver Twist, the quarrel between husband and wife in Dombey \& Son, or Mrs. Dombey's dismissal of Carker - illustrate this characteristic differentiation. The double drowning near the end of Our Mutual Friend suggests an enlightening parallel in George Eliot. Rogue Riderhood, who for purposes of blackmail, has quietly possessed himself of proof of Bradley Headstone's brutal assault on Wrayburn, has called the young man to the weir to make known the terms of silence. Not a significant change of attitude in either actor is allowed to go unrecorded. The rising insolence of the rogue as he smokes his pipe, the rising voice, the contemptuous snapping of his fingers, the momentary vehemence of his "I'll be paid!" the growing desperation of the victim from the time of his contemptuous laugh at the gross demand for his watch, the white tenseness of his face as he begins to realize the extent of Riderhood's demands and the certainty of power to enforce them, his clutch with one hand upon the other's wrist, the final fixedness of despair represented by the night vigil in the window beside the lock - all this is significant not only because it is elaborately exact, but because it is the sole means of indicating Headstone's mental progression. Here is a man ultimately driven to murder and self-destruction; yet what goes on behind the words and gestures it was contrary to the dramatic method to reveal. In short, 
more than other novelists of their time the Dickens group elected to impose on themselves something approximating the necessary restrictions of the spoken drama. For them it was a badly told story that got itself clogged with commentary. Their business was to visualize their scene, to report it undecorated by exposition, as we should see it in life. It has for us the same puzzlement as to its meaning, its bearing on the intrigue that any chance conversation might have. "The story must stand for itself" was a principle that Dickens insisted upon repeatedly. This principle coincides with Reade's, that the chit chat must indicate his characters just as it does in real life, and his repeated objection to analysis of motive as interrupting the course of the sacred narrative and blurring the physical outline of his picture.

The drowning of Grandcourt in Daniel Deronda through Gwendolen's hesitation in offering assistance is "a fertile situation" such as the Dickensians especially affected, the presentation of which is the plain reverse of their methods. The outward action - the drama - of the catastrophe, to George Eliot is nothing. So insignificant is her interest in the outcome of Gwendolen's evil marriage as pictorial that she does not even attempt to visualize it. On the wharves, spectators observe that there has been an accident in the English milord's boat and that there is a body overboard - whether of man or woman they cannot tell. The importance appears only in a subsequent chapter when Gwendolen confesses to Deronda that in intent she is a murderess. It is only the hesitation, the crime in thought, and its ultimate reaction upon the heroine that matter.

The essential differences inherent in these two theories of fiction may be seen and felt in these parallel citations from Daniel Deronda and Griffith Gaunt. The husband, suspecting Gwendolen's desire to talk privately, determines 
to circumvent her. She has rejected his proposal for boating. "Presently Grandcourt came in with his hat on, but threw it off and sat down sideways on a chair nearly in front of her, saying in his superficial drawl, -

" "Have you come round yet? or do you find it agreeable to be out of temper? You make things uncommonly pleasant for me.'

"'Why do you want to make them unpleasant for me?' said Gwendolen, getting helpless again, and feeling the hot tears rise.

" Now, will you be good enough to say what it is you have to complain of?' said Grandcourt, looking into her eyes, and using his most inward voice. 'Is it that I stay indoors when you stay?'

"She could give no answer. The sort of truth that made any excuse for her anger could not be uttered. In the conflict of despair and humiliation she began to sob, and the tears rolled down her cheeks, - a form of agitation which she had never shown before in her husband's presence.

"'I hope this is useful,' said Grandcourt, after a moment or two. 'All I can say is, it's most confoundedly unpleasant. What the devil a woman can see in this kind of thing, I don't know. You see something to be got by it of course. All I can see is, that we shall be shut up here when we might have been having a pleasant sail.'

" 'Let us go, then,' said Gwendolen, impetuously. 'Perhaps we shall be drowned.' She began to sob again.

"This extraordinary behavior, which had evidently some relation to Deronda, gave more definiteness to Grandcourt's conclusions. He drew his chair quite close in front of her, and said in a low tone, 'Just be quiet and listen, will you?'

"There seemed to be a magical effect in this close vicinity. Gwendolen shrank, and ceased to sob. She kept her eyelids down and clasped her hands tightly. 
"'Let us understand each other,' said Grandcourt, in the same tone. 'I know very well what this nonsense means. But if you suppose I am going to let you make a fool of me, just dismiss that notion from your mind. What are you looking forward to, if you can't behave properly as my wife? There is disgrace for you, if you like to have it, but I don't know anything else; and as to Deronda, it's quite clear that he hangs back from you.'

"'It is all false!' said Gwendolen, bitterly. 'You don't in the least imagine what is in my mind. I have seen enough of the disgrace that comes in that way. And you had better leave me at liberty to speak with any one I like. It would be better for you.'

"'You will allow me to judge of that,' said Grandcourt, rising and moving to a little distance towards the window, but standing there playing with his whiskers as if he were awaiting something.

"Gwendolen's words had so clear and tremendous a meaning for herself that she thought they must have expressed it to Grandcourt, and had no sooner uttered them than she dreaded their effect. But his soul was garrisoned against presentiments and fears; he had the courage and confidence that belong to domination, and he was feeling at that moment perfectly satisfied that he held his wife with bit and bridle. By the time they had been married a year she would cease to be restive. He continued standing with his air of indifference, till she felt her habitual stifling consciousness of having an immovable obstruction in her life, like the nightmare of beholding a single form that serves to arrest all passage though the wide country lies open.

"'What decision have you come to?' he said presently, looking at her. 'What orders shall I give?'

"'Oh, let us go,' said Gwendolen. The walls had begun 
to be an imprisonment, and while there was breath in this man he would have the mastery over her. His words had the power of thumb-screws and the cold touch of the rack. To resist was to act like a stupid animal unable to measure results. So the boat was ordered. ...."

Griffith Gaunt, returning home after long absence resulting from a quarrel, finds his wife entertaining guests at dinner. Their covert reproofs to each other are enough to disperse the company shortly. Then -

"'What sort of a reception was that you gave me?'

"This was too much. She turned on him furiously. 'Too good for thee, thou heartless creature. Thomas Leicester is here and I know thee for a villain.'

"'You know nothing,' cried Griffith. 'Would you believe that mischief-making knave? What hath he told you?'

" 'Go back to her,' cried Mrs. Gaunt furiously. 'Me you can deceive and pillage no more. So, this was your jealousy! False and forsworn yourself, you dared to suspect and insult me. Ah! and you think I am a woman to endure this? I'll have your life for it! I'll have your life.'

"'Griffith endeavored to soften her; protested that, notwithstanding appearances, he had never loved but her.

"'I'll soon be rid of you, and your love,' said the raging woman. 'The constables shall come for you to-morrow. You have' seen how I can love, you shall know now how I can hate.'

"She then, in her fury, poured out a torrent of reproaches and threats that made his blood run cold. He could not answer her; he had suspected her wrongfully, and been false to her himself. He had abused her generosity and taken her money for Mercy Vint.

"After one or two vain efforts to check the torrent, he sank into his chair, and hid his face in his hands. 
"But this did not disarm her, at the time. Her raging voice and raging words were heard by the very servants, long after he had ceased to defend himself.

"At last she came out, pale with fury, and finding Ryder near the door shrieked out, "Take that reptile to his den, if he is mean enough to lie in this house'; then, lowering her voice, 'and bring Thomas Leicester to me."'

Such at its best were the lineaments of the sensationalism which half a century ago held spellbound the readers of popular periodicals. It called for a tale of violent passions and relied particularly upon melodramatic devices of mystery, surprise, coincidence, and fortuitous intervention. More than other fiction of the time its makers tended voluntarily to observe some of the restrictions which the playwright's medium necessitates - notably avoidance of psychological analysis of motive and reaction - and to conduct the story largely by means of dialogue. It was a rarefied romance with a specialized narrative technique. Vividness, vigor, rapidity it promoted. To the modern taste the vividness often seems garishness; the vigor, rant. But the method could hardly fail to teach even those who cared little for its characteristic romance materials how to devise and accent the scene. Even Trollope, who, as a maker of novels, despised Dickens's school root and branch, confesses as much. How much popular melodramatists since have learned especially from Dickens cannot be determined. Undoubtedly it is much. Moreover, in the ultimate repudiation of the conventional three-volume length, this sensational novel pointed the way to a briefer, more workmanlike story. The preoccupation with plot, together with the deliberately external treatment of the dramatis personae, tended to sketchiness and indistinctness of character. This is most apparent in the work of the younger. men whose persons are but too easily forgotten when one 
closes the book. In the Dickensians relics of terrorism, the theater, and the new passion for fact of a sort - the unusual fact - met and intermingled; and the result was, perhaps, the golden age of the dime novel.

\section{Reade's Reduction of Sensation Principles to Absurdity}

The style which Charles Reade evolved from the fundamental sensation-dramatic creed, like his singular genius, was unique. In the theater his friend Coleman observed that "despite Reade's elaborate theories of art, he was only guided by actual practical results." "I have frequently known him," Coleman proceeds, "take grave exceptions to an actor's conception of a part at rehearsal; but if the offender struck fire at night, the end justified the means, even if his views were diametrically opposed to those of the author." Still, as it has been sufficiently indicated that "effect first" is the general canon of sensational novels from. Gothicism onward, to distinguish the trait in Reade is merely to align him with the tradition in general. He was, in fact, an extremist. His narrative rhetoric represents the culmination in Victorian times of the doctrines represented by the dramatic group, just as George Eliot's later manner represents the culmination of the realists' tendencies. This antithesis mainly explains Reade's absurd antipathy to the author of Daniel Deronda.

In Dr. Thorne there is a lover's quarrel between Mary and Frank Gresham, for the rather prosy style of which Trollope apologizes as follows: "Were I possessed of a quick, spasmodic style, I should have been able to include all - Frank's misbehavior, Mary's immediate anger, Augusta's arrival and keen Argus-eyed inspection, and then Mary's subsequent misery - in five words and half a dozen dashes. The thing should have been told so." It was one 
of Reade's distinctions that he could tell the thing so. "The truth is," he remarks in Hard Cash, "that epics, dramas, novels . . . all narrative, true or fictitious, except those, true or fictitious, which nobody reads, abridge the uninteresting facts as nature never did, and dwell as nature never did upon the interesting ones." 1 His workmanship was unique among Victorians because from Peg Woffington to $A$ Perilous Secret he resolutely practiced condensation. The burlesque creed of Punch's prospectus for The Sensation Novel Company, Limited, in so far as it relates to narrative method, is Reade's serious code. Believing that narrative effects hit hardest when put in the fewest words possible and the plainest, he made all else subordinate to the purpose of getting on with his incident, and studied brevity and picturesqueness.

How unusual a distinction of style in Victorian fiction this is will readily be perceived from what has preceded. Most novelists, indeed, were so well content to follow Trollope's practice of making their story fit the three-volume convention that a study of the methods of dilution and divagation among the great Victorians would be worthy a place among the curious essays of Disraeli the elder. Nor was brevity especially sought by Reade's own group: Dickens, whatever else he was, was a garrulous sentimentalist, most so assuredly in his most dramatic moments; Collins wrote an exact but pedestrian style which seldom struck sparks out of his elaborately analyzed materials. In the interest of the qualities Reade sought, that energetic novelist reduced his stories as far as possible to dialogue, minimized set description and analysis of motive, made a fetich of employing the Saxon vocabulary, and defied printer's conventions right and left. As a result he never dawdled over - nor spared - the most terrific effects.

${ }^{1}$ Hard Cash, Vol. II, ch. XVI. 
Between Peg Woffington and It is Never too Late to Mendsomewhere, that is, in the first five years of the second halfcentury, while he was still dramatic hack to Tom Taylor Reade was evolving the principles of fiction which he practiced to the end. There are numerous entries in his journal for the period intervening between the first experimental tale and the first great hit, none of which perhaps has more meaning than this: "When in a novel you find yourself about to say something, pull up and ask - can't I make one of my dramatis personae say it? If you can, always do." 1 This emphasis on the spoken word, particularly in the younger men of the dramatic trio, has not quite escaped attention. Something of the care they expended upon, and of the importance they attached to it, Sir Walter Besant perceived when Collins in his last illness turned over to him for completion the story, Blind Love. ${ }^{2}$ Wilkie's notes, his collaborator affirms, were a complete, detailed scenario. More than this, "There were also fragments of dialogue where dialogue was wanted to emphasize the situation and make it real. I was much struck with the writer's perception of the vast importance of dialogue in making a reader seize the scene. Description requires attention; dialogue rivets the attention." But neither Collins nor Dickens reduced their narrative material so far to dialogue as Reade. It is this trait of the Readean tale that Mr. Howells felt when he said: "You seem to be reading a dramatization of his novels rather than the novels themselves.'

The extraordinary bulk in Reade, the multifarious purposes he makes it serve, and the rapidity with which it hastens on his typical scene are logical effects of his creed which criticism has largely neglected. The fact is that

1 Quoted in Memoir of Charles Reade, p. 209.

2 Besant's prefatory note to that story. 
from two fifths to one half the entire bulk of the characteristic novel by Reade consists of words in the mouth of some fictitious character. Peg Woffington and White Lies, both made originally from plays, have the highest percentage; A Terrible Templation has two fifths. The famous prison episode in Never too Late, comprising about a third of the entire story and embodying one of the most virulent preachments that even Reade ever devised, is almost exactly one half dialogue or monologue. The relative amount would seem to be considerably less only in Griffith Gaunt, where Reade, taking a leaf from the book of the realists, tried his hand at a psychological study of jealousy. Still mere dependence on the spoken word of itself proves little. Dialogue may, as the elder Dumas knew, be a very serviceable space filler. If three persons were asked to name the least dramatic of Victorian novelists, one at least would be sure to answer Benjamin Disraeli. Yet Sybil, for instance, is little more than a succession of dialogue. Bulwer, too, especially was fond of employing it to exhibit his acquaintance with art, politics, philosophy, what not - of making it serve, in short, many other than strictly narrative purposes. Absolutely speaking, however, without reference to other considerations the proportions cited from Reade are very high - higher probably than in any other novelist of his rank. Trollope's Warden, for example, is about one fifth dialogue. Felix Holt and The Mill on the Floss have slightly less than one third, Great Expectations slightly more than a third. But these instances demand a word more of explanation. Felix Holt and The Mill on the Floss depend more upon dialogue than later tales of George Eliot, not only because the expository-psychological method grew upon her with time, but because The Mill is notoriously out of proportion in the long conversations early in the book by means of which Mrs. Tulliver's relatives exhibit them- 
selves. The significance of Reade's dependence upon the spoken word is then not less in the relative amount than in its invariable employment to further narrative. Even his very partisan preachments against prison regimen are reduced to this narrative formula.

If this reduction of the story to spoken words savors, as Mr. Howells intimates, overmuch of the stage, it nevertheless imparts to Reade's scenes a rapidity which few novelists ever maintained. The dialogue is brisk in its rapid and constant interchange, unbookish, natural, weighted by no special significance beyond that which the words bear on their faces, always intended to get the story on with as litte elaboration as might be. Hence current journalistic criticism, unaware of his real aim, sometimes counted it a defect that his tales had not the very elaboration which he made a principle of avoiding. It would have been much nearer the truth to say that few or no contemporaries rivaled him in getting done expeditiously a tremendous amount of narrative business. None of his rivals surely could have equaled the brevity and economy of style in the narrative of David Dodd's homecoming, or in the masterly exposition of the causes for the rift between Griffith Gaunt and his wife.

This reduction of the story to the spoken word was only one phase of Reade's struggle for brevity. With it the determined minimization of set description and the contemptuous avoidance of psychological analysis are consonant enough. He may choose to lay the scene in the mad house, where he is acquainted with both appliances and methods of dealing with patients, or in an island of the Pacific, where he knows the climate and vegetation like a mariner who has sailed those waters all his life, or in the Australian bush, where he knows with equal certainty the life of the mining camp or of the aborigine. How the native dresses, climbs a tree, follows a trail, or lights a fire - it was with things such 
as these that Reade made himself thoroughly familiar. The subject might involve asylums for the insane, forgery, or ship knackers; he always had a fund of highly specialized information; but decorative description in the Radcliffian and Dickensian manner he contemned utterly $\downarrow$ and except in The Cloister and the Hearth, where the spirited panorama of Gerard's journey to Italy indicated what he could do if he would, there is hardly background in the conventional sense in his stories at all. The old Cairnhope church in Put Yourself in his Place in which Little maintains the secret forge as he fights against the unions is the one external object in Reade's contemporary stories which lingers in memory.

In sketching persons he is pithy but never detailed. "It is usual," he says of Jacky, the native of the brush in Never too Late, "in works of this kind to give minute descriptions of people's dress. I fear I have often violated this rule. However, I will not in this case. Jacky's dress consisted of, in front, a sort of purse made of ratskin; behind, a bran new tomahawk and two spears." Guy Raby, the crusty Tory squire in Put Yourself in his Place, is epitomized in two trenchant sentences. "He had a sovereign contempt for tradespeople, and especially for manufacturers. Any one of those numerous disputes between masters and mechanics which distinguish British industry might have been safely referred to him, for he abhorred and despised them both with strict impartiality." 1 The spirit of his entire fiction in this respect appears in Hard Cash, where Peterson, an Oxonian who has just seen Julia Dodd, "launches into a rapturous description of the lady's person well worth leaving out." This absence of detailed description is anomalous in Victorian fiction; given Reade's stock of technical information, from which he might have readily elabo-

${ }^{1}$ Put Yourself in his Place, ch. 1. 
rated such description, its absence can only mean that "the drama" is always the primary consideration. His whole rhetoric is designed for the purpose of throwing rapid narrative into the boldest possible relief.

In accordance with this principle of throwing the dramatic into high relief, the rejected psychological analysis and exposition almost entirely. "In life," he declared, "people don't come to you labeled, explanation in hand." ${ }^{1}$ His quarrel with realists like Tom Robertson and Trollope was thus a double one - their stuff was merely "the chronicle of small beer," their method was small and languorous. In his own words again, they describe with "marvelous accuracy the habits, manners, customs of animalcules as they might be seen under the microscope." Of Shilly Shally, the play which he made over from Trollope's Ralph the Heir without the novelist's consent, he averred: "Trollope as condensed by Reade succeeded by a law of nature." The same idea recurs in his dictum that George Eliot's style lacked "fire." The real importance of this tenet, however, appears best in concrete illustration. In Griffith Gaunt, Kate, the wife, an ardent Catholic, infatuates an eloquent priest, Father Leonard, who so far forgets his vows as to declare his love. "Her mind," says Reade, "was in a whirl; and were I to imitate those writers who undertake to dissect and analyze the heart at such moments, and put the exact result on paper, I should be apt to sacrifice truth to precision; I must stick to my old plan and tell you what she did; that will surely be some index to her mind, especially with my female readers." ${ }_{2}$ The rest, of course, is mainly dialogue; and the conclusion of the scene is illustrative of the laconic nature of the comment which Reade's dramatic method imposes. Kate begs her husband to take her abroad, out of temptation's way; but he, like an oaf, objects that his

1 Note at conclusion of Love me little.

${ }^{2}$ Grifith Gaunt, ch. 13. 
hay is down. This obtuseness drives the impetuous woman frantic. At her rage "Griffith smiled with that lordly superiority the male of our species sometimes wears when he is becoming like our dull ass; and smoked his pipe, and resolved to indulge her whim as soon as ever he got his hay in." Or again, in Foul Play, Helen Rolleston, the heroine, has to tell her betrothed that she has transferred her affections to Penfold, the ticket-of-leave man. After she has made an appointment with Wardlaw, her affianced, for the next afternoon, the text goes - "and so she retired, leaving him in ecstasies. This was the first downright assignation she had ever made with him.

"They met at one o'clock; he as radiant as the sun and with a rose in his button-hole; she sad and somber with her very skin twitching at the thought of the explanation she had to go through." This is all that intervenes at a point where a Victorian realist would most likely have furnished a chapter of analysis or commentary. No contemporary so far abjured the novelists' prerogative of showing readers about and into his persons. More than another he deliberately chose to impose upon himself the limitations which the stage necessarily imposes. Commentary upon the persons, like decorative description, was merely a profane interruption of the sacred narrative. Hence the extraordinary amount of incident in Reade's novels. Almost any one of them, indeed, contains enough to make a round half dozen of the kind usually accounted adventurous since his time.

This negative creed of condensation and omission, however, tells only half the story. Reade went further; and to adopt a current phrase that the novelist appropriately might have invented, had a positive doctrine for "putting over" his effects. In The Autobiography of a Thief, which purports to be written by Tom Robinson, whose reform is dealt with at length in Never voo Late, and to be revised by Mr. Eden, 
the model prison chaplain, the thief puts down "collected" or "took with me" for "stole." Mr. Eden, who serves throughout the story as Reade's mouthpiece, comments characteristically upon the euphemism: "Never tamper with words; call a spade a spade, a picklock a picklock. That is the first step to digging instead of thieving." Or, as he put it in reference to some of his representations concerning dramatic copyright: "What I said to Maquet in vile French I have said over and over again to my own countrymen in some of the best English going. I mean by best, the plainest." One could not, Reade held, improve upon calling a spade a spade unless one printed a cut of it - a practice of which he was exceedingly fond.

So then this sensation novelist, who wastalso an Oxford don and an LL.D. was a resolute champion of the Saxon vocabulary. The obliquity and ponderosity of the language of medicine and of the profession to which he was educated especially stirred his contempt. "The oleaginous periphrasis" of physicians is satirized with Reade's customary heavy-handedness in the person of Dr. Wycherley, the alienist in Hard Cash. "In short," Reade makes that worthy say, as a final effort in clarifying a highly technical explanation of young Alfred Hardie's condition of mind, "it is the premonitory stage of the precursory condition of an organic affection of the brain." 1 On the word brain the novelist comments: "What a blessing there are a few words left in all our dialects." Previously he had translated Wycherley's circumlocutions not unaccompanied with and not undisturbed by as plain accompanied and disturbed. His favorite characters are like their creator, who, as he remarked in comparing himself with George Eliot, "uses few words after his kind," just as she after her kind uses many. It is held equally to the credit of the reformed courtesan in $A$

${ }^{1}$ Hard Cash, ch. 24. 
Terrible Temptation who turns evangelist, and to that of Rolfe, the writer in the same story, who represents Reade himself, that they "know how to speak the Saxon language." 1 In our early acquaintance with the young seaman, David Dodd, we learn that he "had sucked in a good deal of language from books and tongues; not indeed the NormanFrench and demi-Latin, and jargon of the schools, printed for English in impotent old trimestrials for the further fogification of cliques, but he had laid by a fair store of the best, of the monosyllables, the Saxon, the soul and vestal fire of the great English tongue. So he was never at a loss for words, simple, clear, strong, like the blasts of a horn." Stray papers, passages in the novels such as these, and the whole texture of his narratives leave it doubtful whether Reade abominated most euphemism or inkhorn terms.

The result is a restless, virile English - energetic, full of fire and color, unmistakably masculine at all times. Whatever it wants of melody, tenderness, grace, it is evident that Reade desiderated quite other qualities. He needed and he evolved a medium for the kind of effect at which his narrative aimed; and so excellent was that medium for the purpose that even Trollope, who held dramatic fiction as cheap as Reade held the Barsetshire series, praised the brightness and spirit of Reade's scenes unreservedly. The author of Hard Cash would have found Schopenhauer's gruff dictum - that the problem of style consists in having something to say and in saying it - the most perfect expression of the whole matter. This unique narrative style, with its business-like repudiation of ornament, dyrical effect, and sentiment, /would have seemed more at home had it come from an Englishman of a century earlier or of half a century later. Its close kinship with eighteenth-century ideals and its anticipation of later journalistic manner are

${ }^{1}$ Love me little, ch. 3. 
evident. Pretty much all that romantic rhetoric meant, save its desire for effect, was lost upon Reade.

This anomalous Saxon brevity was not enough for a thorough-going sensationalist like Reade. The boredom of readers is always a matter of unusual importance to romancers of his kind; but none of his stature in English has had quite the courage to provide against the contingency by such unconventional devices. He steadily counted on the singular appearance of his printed page to stimulate attention. It is an excessively broken page, abounding in sentence paragraphs, tricks with the type, and unique childish illustrations which recall the vagaries of Sterne and of Dickens. No one knew better the superior attractiveness of the broken page or used it more invariably. It is not merely that the exceptional bulk of Reade's dialogue tends in this direction, nor is it merely that he is studiously brief in exposition and set description. $\mathrm{He}$ broke the essential minimum of these into small, readily absorbed fragments, and thus made the printer serve his sensation principles. Chapter $\mathrm{X}$ of Hard Cash, in which the storm breaks upon Dodd's ship, the Agra, ends with about forty paragraphs quite free from dialogue. The longest of these is about two hundred words, the shortest contains but two words. There are others consisting of four and seven respectively. The average here, from sixty to seventy, is representative of Reade's customary practice. In Griffith Gaunt, George Neville, who feels that he has been lightly used by Kate Peyton, writes four notes of reproof, no one of which suits him. Each note is described in one sentence; the four are parallel in construction, and each constitutes a paragraph by itself. In the same story, when Mrs. Gaunt is about to appear before the court in her own defense, Reade sketches the scene in a succession of twenty-five consecutive sentence-paragraphs. All this looks like imi- 
tation of French prose - more specifically perhaps, imitation of Eugène Sue and Dumas the elder; if it was so, however, enough has been said previously to indicate that there is nothing remotely Gallic in its idiom. How far removed such broken pages are from the conventional prose of the Victorian novel one needs only to open to any chapter of exposition or description at random to ascertain. It will be found that the passages comparable to this, not only in Trollope and George Eliot but even in Bulwer and Dickens, tend to observe the general paragraph length of present-day prose say from one hundred and fifty to about two hundred and fifty words.

Reade ignored more conventions than this, however. The printer's devil had a more active part to play in his style than in that of any of his contemporaries - for he calls where he chooses for large type and for small, for italics, and for illustrations generally thought to be in place only in primers. When Mrs. Gaunt's intimacy with Father Leonard is becoming dangerous, she and the servant, as they arrange his room, discover among his keepsakes a woman's glove. Upon examining it, the servant squawks out in big type - LAWK A MERCY; IT'S YOUR OWN, and the curtain falls. The fight between David Dodd's ship and the pirate is at its height when the cabin boy runs up to the captain with the information that the ammunition is low. The lad's whisper is represented by diamond type. Again Tom Robinson proposes: "Don't cry so, dear girl. I've got a question to ask you. IF I COME BACK A BETTER MAN THAN I GO, WILL YOU BE MRS. ROBINSON?" The final word in the chapter is the woman's small typed "yes." Still again when Kate Peyton finally accepts Griffith Gaunt she enjoins him: "You make me plight my troth with you whether I LIKE IT OR NOT." 
The purpose of this chicanery with the type - to render visible the tone for that tremendous final sentence before the curtain falls, and for the stage whisper - would be unmistakable did we not have Reade's own justification for them. As explanation to similar procedure in It is Never too Late to Mend he appends a note to the effect that "these imprecations are printed on the ascending scale by way of endeavor to show how the speaker delivered them." In the same category come his cuts - that graphic representation of Uncle Fountain's mind in Love me little, which reveals the county as larger than Britain, and Britain larger than the world, or the sketches of the Southern Cross and of the knife with the nuggets clinging to it in Never too Late. How seriously he took these unconventionalities may be inferred from a portion of one of his letters to Ticknor \& Fields, his American publishers. "I cannot help feeling some anxiety about your woodcuts, and this anxiety is increased by your silence, which leads me to fear I have not succeeded in showing you the importance of those effects I aim at by them. These are no vulgar illustrations; they are not done upon the common plan of illustrations. They take the place of text, and the reader reads them as well as views them." 1 The tombstones and knives must be like, he insists, or both they and the text must be omitted. Reade's taste was not that of the formalist. The strange fact is that few narrative prose styles have so little needed meretricious aids such as these. But Reade never endangered being understood even by the dullest. LFor him the writer who refuses to attain the desired effect by the readiest means was simply a fool

In a style thus studiously brief and sensational the main characteristics of Victorian sensationalism at its best stand

${ }^{1}$ The Century Magazine, November, 1884, p. 67. A letter to Ticknor \& Fields. 
out sharply. Reade was vain and eccentric enough more than once naively to express in print his unbounded admiration of his own genius. Of Foul Play he once wrote anonymously: "It is a novel of immense power, of the greatest originality, and is one of his works that shows best the boundless resources of the writer. This feature must strike every reader of Charles Reade's novels; his resource is unlimited; his incidents, novel and striking, yet always possible and natural, follow one another with startling rapidity. Foul Play showed off to perfection his ingenuity." 1 His aims rightly understood, this judgment may be allowed to stand almost intact. Like his "brother in the art" Collins, he did the things he intended so well that the main question is whether the thing itself was worth the pains and art lavished upon it. For after all the brilliance is mostly at the surface; his novels read as if they had more significance while you hold the book than they really possess. Their tremendous energy and kaleidoscopic vividness and variety of incident have little real meaning. Their virtuosity is still amazing - only less so than Collins's; but it is the virtuosity of a man more in love with the glare of the footlights than that of common day. Not even Stevenson was more exclusively and hopelessly a writer of story books.

Whatever else may have operated in limiting Reade's work to an exercise of professional dexterity in narrative art - and there were other influences such as his preoccupation with books, the theater, and academic life - it is clear that the narrative creed tended in the same direction. The whole scheme minimized character interest. Neither he nor Collins realized that either character or intrigue must be in the ascendant. The consequence is that most Readean folk, like Collins's, slip quickly out of mind. Among his men Denys the Burgundian in The Cloister and 
the Hearth, David Dodd, and the eccentric Dr. Sampson in Hard Cash are something more than stalking horses for exciting melodrama. The generality of his heroes, manly, likable fellows enough, who are ready to fight hard, love truly, and endure, have little identity apart from the story which they help to carry on. When Henry Little in his fight with the unions meets Grotait, the organization leader at an inn, to settle their differences, he rips out the toast "Here's quick exposure, sudden death, and sure damnation to all hypocrites and assassins." The action and the sentiment are tolerable expression of the reason for being of George Fielding, Penfold, and the others. About them personally we have small concern; where they will "come out" we feel tolerably sure. They play their assigned part in the melodrama acceptably, but we leave them little the wiser ourselves, without having made new friends of them. "Fertile situations," as Reade understood and applied the term, practically precluded that.

With his women the matter is somewhat different. Mr. Howells feels that Reade knew the other sex better than Thackeray or Dickens and could "paint their manners, if not their minds, better than both his betters put together." $\mathrm{He}$ also ascribes to Reade the creation of the "coquette manquée," by which he means "a flirt in whom the impulse of flirtation is arrested or interrupted by a throe of conscience or a thrill of passion, and who for peace's sake or love's sake is willing to forego the pleasure of winning a heart to no other end than feeling it hers." A gallant man, Reade, in truth, always found that period when young womanhood is first conscious of lovers - while the unsophistication of girlhood still lingers in the maturing woman - especially fascinating, and drew upon it for his best characterizations. Lucy Fountain, Julia Dodd, and Kate Peyton are charmingly fresh specimens of conceivable girlhood. But Reade's 
scope was limited. More ambitious attempts - that to realize Peg Woffington or Mrs. Gaunt - show the same weakness as the men. The drama and the style of Reade too arbitrarily condition and repress their individuality. It would be difficult to find a better conception for melodrama than that in Peg Woffington or to make a happier choice of heroine. But in the interests of drama she is put through the absurd picture scene, which, as Swinburne remarks, is good only to make the fortunes of a farce; and the pathos of a wronged wife's appeal to a stronger and victorious rival is lost in garish theatrical clap-trap. Likewise, Mrs. Gaunt, for the most part an admirable study in ardent heroic womanhood, Portia-like, becomes her own advocate in trial for murder, and delivers a plea of which the seasoned barrister need not be ashamed. That is, if Reade's excessive objection to analysis necessitated, according to common canons of fiction, some shadowiness of character, he increased the difficulty by ruthlessly subordinating his persons to the exigencies of his drama. Such things as these, we have seen, Reade held to be "the true cream of fiction." The result is the frequent vulgarization of such real drama - conflict of character - as his stories contain. Situation and climax crash down upon his readers like well-aimed blows of a single stick player, until they are battered into a kind of emotional insensibility that nothing but floods or earthquakes can touch. The method defeats itself by excess of the quality it aimed at. Reade's ponderous folios of clippings never taught him that the inhabitants of certain regions of the earth learn to live unmoved in the neighborhood of earthquakes and volcanoes.

There are more egregious sacrifices to the creed than Peg Woffington. Griffith Gaunt, a finely conceived tragedy of alienation of husband and wife, is disfigured by the introduction of Caroline Ryder, Mrs. Gaunt's maid, whom 
Reade describes as "a female rake." Without this wretched creature, who exists mainly in order to bear tales and solicit her mistress's husband, the situation has all the potentialities of grave and affecting tragedy; the wife high spirited, ardent, a devout Romanist, the husband an ale-drinking squire and lukewarm Protestant who rises above being a mere oaf by virtue of a jealous affection for his wife. Reade never wrote better, not even in The Cloister and the Hearth, than in the early chapters of Griffith, in which the rift between Kate and her husband appears. With the introduction of the eloquent but youthful Father Leonard the material for tragedy is complete; but in the passion for concreteness, the desire to make the plot work by visible and tangible means, he imposes upon the story this personification of falsehood and lust - a gross, nasty blot upon a finely human and pathetic drama of misunderstanding. His "drama" justified the outcry of "carrion" that Goldwin Smith raised. There is a more notorious instance of this vulgarization in $A$ Terrible Temptation, which has as its problem - given a doting but childless wife to a man whose heart is set on having a son and heir, how will the woman's ingenuity deal with the situation? In this romantic world of Reade's, of course, Providence will ultimately provide the heir. The novelist's immediate answer, however, is that a Bella Bassett will almost succumb to the temptation of palming off the child of another for her own. But for our dramatist this sensational answer is somewhat tame; and so he provides a cheap mystification in which we are led to suspect that she has a child by a Mr. Angelo, a clergyman. Both clergyman and wife, it is almost needless to say, are models of rectitude. The paltry obfuscation is there large in Reade's pages, let him roar in footnotes and appendix in attempted palliation however he will; and the instance points clearly enough to a practical working prin- 
ciple of which he was probably never aware; that of never letting a character stand in the way of an effect.

The heated controversies in which Reade urged his priority over George Eliot are no longer debatable. The pit, the decision of which he knew to be final, has long since decided against him. The reason is largely that he was less a student of life than a doctrinaire virtuoso in narrative art. He is like performers at the vaudeville who climb six rounds of the ladder balanced upon the slack wire and then balance themselves upon one foot. The feat is a marvel of skill but has no especial significance to-morrow. The certainty of his skill, the vigor, the rapidity in his workmanship are those of the virtuoso in his craft. Furthermore, from the very definiteness of the creed Reade's work gave him the finest of all satisfactions in art - that of achieving one's design with distinction; for it is stupid to see nothing more than arrogance and vanity in the man's naive self-praise. $\mathrm{He}$ is mainly voicing a wrongheaded faith in his creed. But if we ask ourselves whither his example tended, what helpful inspiration came from it, the answer for all Reade's singularly original genius - indeed largely because of it - is unmistakable. The style was specialized so highly as at times to be almost burlesque. He left few or no successors within the domain of literature proper. Just as he appropriated some of the least admirable traits of his master, so in turn he furnished hints useful mainly in the craft of writers who a generation ago turned off reams of stories in yellow covers. For what Dickens was to Reade, Reade was to the dime novel of our boyhoods.

\section{Summary}

"Sensation novel" was Victorian parlance for romance for the populace. Its especial bailiwick was the twopenny, - sixpenny, or even the shilling miscellany. It affected 
particularly contemporaneity and depended primarily upon the appeal to fear. It was the narrative of villainy, violence, and crime; a delineation of the abnormal, the terrible, and the hideous in some measure for their own sake. To this romance of contemporary life the Dickens group added what they believed to be a scrupulous dependence upon fact, and sought to achieve a refinement in method by - adapting more than fellow novelists the mode of expression that is necessary for the play. More specifically, they favored unusual reliance upon incident and dialogue to reveal character, emphasis upon the number and intensity of climaxes, and avoidance of psychological exposition. Such a scheme of narrative assumes the priority of incident, situation, and plot over character and humor. This position brought them into sharp and resolute contrast with the realists. The opposition appears most sharply between Reade and George Eliot, who represent the Victorian extremes of their respective groups. This more or less distinctive form of sensation fiction Dickens and his friends liked to call the dramatic novel.

The dramatic novel was molded by three influences chiefly - by the trade conditions resulting from the rise of the democratic audience, by devotion of the group to the theater and its methods, and by the tradition of terrorism in the English novel. Trade conditions and the circumstances which evoked them afford the clue to the spirit of their work and largely determined its form. Instalment writing clearly tended to accentuate the favorite devices of their narrative; but the probability is that, so far as the Dickensians are concerned, the effects of serial writing may easily be overemphasized; for their parallel of novel and play implies reliance upon much the same narrative expedients that serialism is popularly held accountable for. Whatever may have been the effect of publication in shilling 
pamphlet or All the Year Round, there exists beneath it and independently of it this dogma of the dramatic, which is to the Dickensians what the foreword to Vanity Fair or to Pendennis was to Thackeray, or what the preface to La comédie humaine was to Balzac. Attempts at distinction between the effects of serial writing and those of their belief in drama upon their narrative form are futile. One set reinforces the other; in effect they are inextricable.

As a literary tradition the history of sensationalism is essentially the history of the rise of the melodramatic method in the English novel since the third quarter of the eighteenth century. It is the lineal descendant not of Scott but of Gothicism; and the direct connection between the two is to be sought in the career of the picturesque ruffian who served as hero for Mrs. Radcliffe, Byron, and BulwerLytton. This hero, the most frequently repeated figure in English romances of the first four decades of the century, from the very conception he embodied, was invariably draped with garish melodrama. Schedoni-Lara-Aram indeed is less important as a person than as a prop for a method. He was merely a chameleon-like obsession of novelists about whom there developed a perennial species of narrative art.

Adherence to their code has cost the Dickensians dear. The younger men achieved two or three stories each which are still read and an honorable mention among the lesser folk in Victorian letters. The vogue of realism brought the reputation of Dickens to its nadir perhaps at the end of his century. His power in other than sensational narrative, aided somewhat no doubt by judicious interpretation, has won approbation anew at the beginning of the next. His satellites may be rejuvenated by the cinematograph, hardly by other means. Nothing in letters becomes antiquated so speedily as the sensationalism of yesterday. As Melmoth in 1820 seemed hectic blasphemous rubbish, so nowadays 
the high tragedy of the Victorians is esteemed rant or unconscious burlesque. Edith Dombey's declamation in the French inn provokes a smile, and Bill Sikes's ghastly death has become proverbial of turgid rhetoric. The modernist who patronizes it may at least remember that it represents the conscious and deliberate code of sincere artists.

The sincere devotion of Dickens, Reade, and Collins to their sensational art had its significance for later makers of fiction. They not only fought valiantly to free their craft from the shackles of philistinism, but they have the honor among the English of first perceiving and emphasizing the dramatic method which has since become a platitude of narrative theory. The Victorian novel, with its bias toward the realistic, domestic, especially needed the qualities upon which they insisted; and their methods, though not their materials, looked forward to and anticipated the defter workmanship of a later time. The dramatic dogma put the emphasis where it belongs in a deliberate attempt to represent the dramatis personae in a livelier and more graphic way than had been attempted previously; and whatever exaggeration of pantomime and of passion it encouraged in Dickens, or willful repudiation of right and necessary modes of expression for the novelist in Reade, it served as a check and corrective for the prosier method to which the domestic variety was prone. 



\section{BIBLIOGRAPHY}

Beattie, William

Life and Letters of Thomas Campbell, 2 vols. Besant, Sir Walter

(1) Autobiography, New York, 1902

(2) The Pen and the Book, London, 1899

Brougham, H. P.

Life and Times of Henry, Lord Brougham, 3 vols. 1871

BULWER-LYTTON

Life, Letters, and Literary Remains of Edward Bulwer, Lord Lytton, by his Son, 2 vols., London, 1882

Burnand, Sir F. C.

Records and Reminiscences. Personal and General, London, 1904

Cazamain, Louis

Le Roman social en Angleterre, Paris, 1906

Cockburn, H. T.

Life of Lord Jeffrey, with a Selection from his Correspondence, 2 vols. Constable, Thomas

Archibald Constable and his Literary Correspondents; A Memorial by his Son, 3 vols., Edinburgh, 1873

Cross, J. W.

-George Eliot's Life as Related in her Letters and Journals, 3 vols.

Curwen, Henry

A History of the Booksellers, London, n.d.

Dolby, George

Charles Dickens as I Knew Him, New York, 1912

Filon, Augustin

The English Stage, Being an Account of the Victorian Drama, New York, 1897

FORSTER, JoHN

The Life of Charles Dickens, 3 vols.

Fox Bourne, H. R.

English Newspapers; Chapters in the History of Journalism, 2 vols., London, 1887

Gates, Lewis E.

Three Studies in Literature (Jeffrey), New York, 1899 
Gordon, Mrs. Mary

Christopher North; A Memoir of John Wilson, Compiled from Family Papers

Harrison, Frederic

Studies in Early Victorian Literature, London, 1906

Hunt, Leigh

Autobiography, revised by the Author, with further Revision, and an Introduction by his Eldest Son, London, 1860

JefFrey, Francis

Contributions to the Edinburgh Review, Philadelphia, 1843

JoRdan, William

Autobiography, 4 vols., London, 1852

Kent, C. B. Royuance

The English Radicals, 2 vols., London, 1899

Knight, Charles

Passages of a Working Life during Half a Century, 3 vols., London, 1873

LANG, ANDrew

The Life and Letters of John Gibson Lockhart, 2 vols.

LOCKHART, JoHn GiBson

Memoirs of the Life of Sir Walter Scott

Mackenzie, R. S.

Life of Charles Dickens, Philadelphia, 1870

Mackenzie, R. S.

The Fraserian Papers of the Late William Maginn, LL.D., with a Life of the Author, New York, 1857 Marzials, F. T.

Life of Charles Dickens, Great Writer Series Melville, Lewis

The Life of William Makepeace Thackeray, 2 vols., Chicago and New York, 1899

Some Aspects of Thackeray, Boston, 1913

MeYnell, Wilfred

Benjamin Disraeli; An Unconventional Biography

Mitton, Geraldine Edith

Jane Austen and her Times, London, 1905

Oliphant, Mrs. Margaret

Annals of a Publishing House; William Blackwoods and his Sons,

3 vols., Edinburgh and London, 1907

Payn, James

Some Literary Recollections, London, 1884 


\section{Reade, Charles}

The Eighth Commandment

Russell, G. W. E.

Sydney Smith, English Men of Letters Series

Saintsbury, George

The English Novel

The Sampson Low Trade Catalogues, London, 1863 and after Shore, W. F. T.

Charles Dickens and his Friends, London, 1909

Scott, Clement

The Drama of Yesterday and Today, 2 vols., London, 1899

ScotT, Sir WALter

Sketch of Mrs. Radcliffe in Biographical Memoirs. Prefatory matter to various Waverley Novels, especially to Guy Mannering, Old Mortality, Kenilworth, The Abbott, The Monastery

Smiles, Samuel

A Publisher and his Friends: Memoir and Correspondence of John Murray, with an Account of the Origin and Progress of the Publishing House, 1768-1843, 2 vols., London, 1891

Trollope, ANThonY

Autobiography

WALKer, HUGH

(1) The Literature of the Victorian Period, London, 1913

(2) The English Essay, London, 1916

WARD, A. W.

Charles Dickens, English Men of Letters Series

Wheatley, Henry B.

The Prices of Books; An Inquiry into the Changes in the Price of Books which have Occurred in England at Different Periods, London, 1898

Bibliography of the Newgate Novel

Representative fictions

Paul Clifford

Eugene Aram

The Autobiography of Jack Ketch

Rookwood

Oliver Twist

Jack Sheppard

Catherine 
Magazine Articles

Fraser's (1) Epistles to the Literati, No. I to E. L. Bulwer, vol. II, pp. $520 \mathrm{ff}$., December, 1831

(2) Mr. Edward Lytton Bulwer's Novels; and Remarks on Novel Writing, vol. I, pp. 509 ff., June, 1830

(3) A Good Tale Badly Told (review of Eugene Aram), leading article for February, 1832

(4) Elizabeth Brownrigge (burlesque of Eugene Aram), vol. VI, pp. $67 \mathrm{ff} .-127 \mathrm{ff}$., (two instalments), August, 1832

(5) Hints for a History of Highwaymen (review of Whitehead's Lives and Exploits of English Highwaymen, Pirates, and Robbers), vol. XX, pp. 279 ff., March, 1834

(6) Highways and Low-ways, or Ainsworth's Dictionary, with Notes on Turpin (review of Rookwood), vol. IX, p. 724, June, 1834

(7) Another Caw from Roodwood; Turpin Out Again (review of third edition of Rookwood), vol. XIII, p. 488, April, 1836

(8) Catherine, vol. XIX, p. 604 (first number), May, 1839 Quarterly Review, vol. XLVIII, p. 391

Lockhart on Bulwer's romances; article entitled Zohrab the Hostage

Edinburgh Review, vol. LXV, p. 209

Mr. Bulwer's Novels

\section{Miscellaneous}

Bulwer's (1) Preface to Eugene Aram, edition of 1840

(2) A Word to the Public, 1847

Chandler, F. W. The Literature of Roguery, 2 vols., Boston, 1907 Dickens's Preface to Oliver Twist

Melville, Lewis

Some Aspects of Thackeray, Boston, 1913

Chapter 4, "Thackeray and the Newgate Novel"

\section{Dickens Material}

(1) Prefaces

Oliver Twist, Old Curiosity Shop, Bleak House, Little Dorrit, and $A$ Tale of Two Cities

(2) Dr. Dulcamara, M. P. (jointly with Wilkie Collins), leading article for All the Year Round, December 18, 1858

(3) Letters of Charles Dickens, edited by his Sister-in-law and his Eldest Daughter, 3 vols., London, 1880-1882 
(4) Charles Dickens as Editor, being Letters Written by him to William Henry Wills his Sub-editor, New York, 1912

(5) Letters from Charles Dickens to Wilkie Collins, edited by R. H. Hutton

(6) Dickensiana, F. G. Kitton, London, 1886

(7) Charles Dickens and his Friends, W. F. T. Shore, London, 1909

The following are specific letters from Letters of Charles Dickens

Vol. I, pp. 77 and 78. Dickens's prologue to Marston's play

The Patrician's Daughter

pp. 174-175 To the Reverend Edward Tagart, Dickens's opinion of Richardson

pp. 210-211 To M. de Cerjal - note on Copperfield

p. 292 To Mrs. Gaskell

p. 293 To Mrs. Gaskell

p. 294 To Wilkie Collins on Basil

p. 352 To Chas. Knight in approval of the public's reading novels

p. 356 Postscript of letter to Frank Stone - Dickens's estimate of relative worth of Smollett's novels

p. 359 To Miss Hogarth - urging merits of Collins's Hide and Seek, which had not especially pleased her

pp. 370-71 To Mrs. Watson on the difficulties of writing Hard Times

Volume II

p. 98 To John Forster describing the nature of his attempt in A Tale of Two Cities

p. 110 To Wilkie Collins on The Woman in White

p. 116 To Bulwer-Lytton on the authorities for $A$ Tale of Two Cities and the adventitious in plot

p. 249 To Mrs. Brookfield - directions for serial publication and general criticism of a novel of hers

p. 276 Advising a young writer against attempting a threevolume story at the first attempt

p. 437 Advising another young writer against exploiting his talent

Volume III

p. 159 To Mrs. Gaskell on the divisions for serial publication of a story of hers 
p. 162 To Miss King in general criticism of a narrative for Household Words

p. 164 To the same

p. 173 To Miss Emily Jolly - general criticism

p. 175 To the same

p. 181 To the same

p. 183 To the same

p. 190 To H. F. Chorley on Roccabella

p. 198 To Bulwer on publication in All the Year Round of $A$ Strange Story

pp. 198-199 To the same

pp. 200-203 To the same

p. 209 To the same

p. 210 To the same

Charles Dickens as Editor, New York, 1912

p. 128 Concerning Miss Furbey, a story for Household Words

p. 141 Concerning North and South - serial method

p. 145 Concerning North and South - serial method

p. 161 Criticism of a story by Wills suggestive of Bleak House pp. 166-167 Letter concerning story by Miss Emily Jolly pp. 168-169 Letter concerning stories by Harriet Parr, Miss Lynn, Miss Jolly

p. 218 Terms for $A$ Rogue's Life

p. 221 Engagement of Wilkie Collins for Household Words

p. 222 Engagement of Wilkie Collins for Household Words

p. 238 Engagement of Wilkie Collins for Household Words

p. 255 Dickens's instructions to Wills concerning Collins and his paper Dr. Dulcamara, M.P.

p. 281 Interview between Reade and Dickens concerning Reade's contributing to All the Year Round

p. 303 Resumption of same subject

p. 307 Suggesting alterations in Wilkie Collins's No Name, which was in course of serial publication in All the Year Round

p. 322 Letter concerning divisions for serial publication of Mrs. Gaskell's A Dark Night's Work

p. 323 Suggestion of name for Reade's story (Hard Cash); Dickens offered as alternative Safe as the Bank

p. 360 Dickens's opinion of The Moonstone 


\section{Charles Reade Material}

(1) Readiana - Chatto and Windus's edition, pp. 260-312, comprising following essays:

A Terrible Temptation, A Suppressed Letter, Foul Play, The Sham Sample Swindle, It is Never too Late to Mend, The Prurient Prude, Second-hand Libel, Facts must be faced.

(2) Anonymous comparison of himself and George Eliot, reprinted in The Bookman, vol. 18, pp. $252 \mathrm{ff}$.

(3) The Charge of Plagiarism Refuted, reprinted in most editions with The Wandering Heir, the novel which gave rise to the controversy.

(4) Reade's notes on The Autobiography of a Thief, Chatto and Windus's edition.

(5) An Acquaintance with Charles Reade, with Letters hitherto unpublished, by Annie Fields, Century Magazine, November, 1884, pp. $67 \mathrm{ff}$. (The letters mostly concern the publication of Reade's novels in America. They are addressed to Mr. Fields of Ticknor and Fields of Boston.)

(6) Charles Reade as I knew Him, by John Coleman, London, 1904. (This book cites Reade's opinions throughout; especially important is Bk. III, Ch. II, Life at Albert Gate, pp. $246 \mathrm{ff}$.)

(7) Memoir of Charles Reade, by Charles L. Reade and the Reverend Compton Reade, New York, 1887. (As in Coleman's biography Reade's opinions on fiction are to be found throughout. Especially important are Chapters XV, pp. $177 \mathrm{ff}$., and XXVIII, pp. $380 \mathrm{ff}$.)

\section{Collins Material}

Works of Wilkie Collins, Chatto and Windus's edition

$\checkmark$ Basil, Letter of Dedication, to Charles James Ward, dated 1862

Armadale, Preface, 1866

The Dead Secret, Preface, 1861

Blind Love, Preface by Sir Walter Besant

Jezebel's Daughter, Letter of dedication to Alberto Caccia, translator, 1880

$\checkmark$ Heart and Science, (1) to readers in general; (2) to readers in particular, 1883

Hide and Seek, Preface, 1861

The Law and the Lady, note addressed to the reader, 1875 
Poor Miss Finch, Dedication to Mrs. Elliot, January, 1872. note to a second edition, November, 1872

No Name, Preface, 1862

A Rogue's Life, Introductory Words, 1879

The Two Destinies, Dedication to Charles Reade, 1876

Letter to Charles Reade concerning Put Yourself in His Place, reprinted in $A$ Memoir of Charles Reade, by Charles L. Reade and the Reverend Compton Reade, New York, 1887, p. 343.

$\checkmark M y$ Miscellanies - two articles

(1) Petition to Novel Writers

(2) The Unknown Public 


\section{$2^{3}$}

\section{VITA}

I was born in Rhode Island, October 13, 1881, and had my schooling in that state. I was graduated from the Rhode Island State College in 1899; took my bachelor's degree from Brown University in 1902, and my master's degree the year following. After two year's work in the department of English at Brown, I was made an instructor, a position I held two years more. Then followed three years as instructor in English at the University of Illinois. The academic years 1911-12 and 1912-13 I did my residence work at Columbia University for the doctorate in English. With that completed, I took an instructorship at Brown to carry on the remainder of my research and the writing of this dissertation. The thesis was accepted and the final oral examination held in May 1918. For the academic year 1918-19 I have been associate professor of English in the University of Maine.

W. C. Phillips 
(116) 



\section{PLeAse do nOt Remove CARDS OR SLIPS FROM THIS POCKET}

\section{UNIVERSITY OF TORONTO LIBRARY}




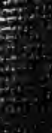

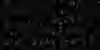

$\therefore \log ^{2}$

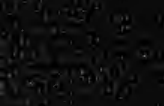

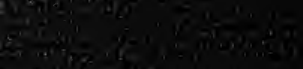

$=\sin ^{2}$

18.

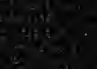

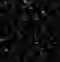

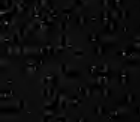

논

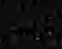

4
8
4
4
4

30

$\rightarrow x^{4}=4$

$-2+\frac{1}{20}$

$-90$

$\log ^{2}$

ti

$x^{2}=3 x$

$\operatorname{lin}$

$4-529$

is. 60

3

$2,9,4$

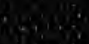

